\title{
PRZEGLĄD ORZECZNICTWA SĄDÓW UNIJNYCH W SPRAWACH ŚRODOWISKA I JEGO OCHRONY W OKRESIE LIPIEC 2010 - WRZESIEŃ 2011
}

\section{UWAGI WSTĘPNE}

W okresie lipiec 2010 - wrzesień 2011 roku sądy unijne (przede wszystkim Trybunał) wydały 29 orzeczeń w sprawach z zakresu prawa ochrony środowiska. Przyjmując przedmiotowe kryterium podziału można wskazać, że w poszczególnych grupach spraw zapadła następująca liczba orzeczeń: ochrona przyrody -7 wyroków, gospodarka odpadami - 6 wyroków, ocena oddziaływania na środowisko - 4 wyroki, ochrona wód - 4 wyroki, informacja o środowisku - 3 wyroki, zintegrowane zapobieganie zanieczyszczeniom i ich kontrola -2 wyroki, ochrona powietrza, substancje niebezpieczne oraz ochrona klimatu - po jednym wyroku.

W przedstawionym poniżej przeglądzie w przypadku blisko połowy ujętych orzeczeń sądów unijnych wraz z sentencją dane-

Doktor nauk prawnych, adiunkt KPOŚ WPiA UMK w Toruniu 
go wyroku przedstawiono omówienie stanu faktycznego oraz cytaty głównych tez z uzasadnienia Trybunału. W pozostałych przypadkach do sentencji wyroków dołączono jedynie krótką charakterystykę przedmiotu sprawy (cytowaną z odpowiedniego numeru Dziennika Urzędowego UE), jak również informację o dostępnych wersjach językowych uzasadnienia. Z uwagi na fakt, że ujęte z przeglądzie orzeczenia sądów unijnych nie zostały jak dotąd opublikowane w Zbiorze Orzeczeń Trybunału Europejskiego, przy każdym wyroku podane jest źródło, którym jest albo strona curia.eu albo rocznik, seria i numer Dziennika Urzędowego UE.

\section{INFORMACJA O ŚRODOWISKU}

\section{II.1. WYROK TRYBUNAŁU Z DNIA 16 GRUDNIA 2010 R. W SPRAWIE C-266/09 STICHTING NATUUR EN MILIEU I INNI PRZECIWKO COLLEGE VOOR DE TOELATING VAN GEWASBESCHERMINGSMIDDELEN EN BIOCIDEN ${ }^{1}$}

1) Pojęcie informacji o środowisku, o którym mowa w art. 2 dyrektywy 2003/4/WE Parlamentu Europejskiego i Rady z dnia 28 stycznia 2003 r. w sprawie publicznego dostępu do informacji dotyczących Środowiska i uchylającej dyrektywę Rady 90/313/EWG, powinno być interpretowane $w$ ten sposób, że obejmuje ono informacje przedłożone $w$ ramach krajowego postępowania w sprawie wydania lub rozszerzenia zezwolenia na dopuszczenie do obrotu środka ochrony roślin w odniesieniu do ustalenia maksymalnej ilości zawartości pestycydów, ich składnika lub produktów przetworzonych w artykułach spożywczych albo napojach.

1 http://curia.eu; dalej cyt.: sprawa C-266/09. 
2) Z zastrzeżeniem, iż taka sytuacja jak ta w postępowaniu przed sądem krajowym nie zalicza się do sytuacji, które zostały wyliczone $\mathrm{w}$ art. 14 akapit drugi dyrektywy Rady 91/414/EWG z dnia 15 lipca 1991 r. dotyczącej wprowadzania do obrotu środków ochrony roślin ${ }^{2}$, przepisy tegoż art. 14 akapit pierwszy powinny być interpretowane $w$ ten sposób, że mogą być one stosowane jedynie wtedy, gdy wskutek tego nie zostaną naruszone obowiązki wynikające z art. 4 ust. 2 dyrektywy 2003/4.

3) Artykuł 4 dyrektywy 2003/4 powinien być interpretowany $\mathrm{w}$ ten sposób, że nakazane $\mathrm{w}$ nim porównanie interesu publicznego, któremu ma służyć ujawnienie informacji o środowisku, z interesem szczególnym dyktującym odmowę udostępnienia informacji powinno odbyć się w każdym konkretnym przypadku przedłożonym właściwym organom, nawet jeżeli prawodawca krajowy określi w przepisie o charakterze generalnym kryteria umożliwiające ułatwienie tej porównawczej oceny istniejących interesów.

W sprawie C-266/09 wniosek o wydanie orzeczenia w trybie prejudycjalnym odnośnie dyrektywy Rady 91/414/EWG z dnia 15 lipca 1991 r. dotyczącej wprowadzania do obrotu środków ochrony roślin i dyrektywy 2003/4/WE Parlamentu Europejskiego i Rady z dnia 28 stycznia 2003 r. w sprawie publicznego dostępu do informacji dotyczących środowiska i uchylającej dyrektywę Rady 90/313/EWG został przedstawiony w ramach skargi o stwierdzenie nieważności wniesionej przez Stichting Natuur en Milieu, Vereniging Milieudefensie i Vereniging Goede Waar \& Co. na decyzję, w której College voor de toelating van gewasbeschermingsmiddelen en biociden odmówił im ujawnienia pewnych badań i protokołów z testów polowych dotyczących

2 Dz. Urz. UE L 230 z 19.8.1991, s. 1-32, uchylona z dniem 13 czerwca 2011 r. w drodze rozporządzenia PE i Rady (WE) nr 1107/2009 z dnia 21 października 2009 r. dotyczącego wprowadzania do obrotu środków ochrony roślin i uchylające dyrektywy Rady 79/117/EWG i 91/414/EWG, Dz. Urz. UE L 309 z 24.11.2009, s. 1-50. 
pozostałości i skuteczności substancji czynnej propamokarb na i w sałacie.

W odniesieniu do pierwszego pytania sądu krajowego College van Beroep voor het bedrijfsleven (Holandia) - Trybunał wskazał, że art. 2 dyrektywy 2003/4 wymienia różne kategorie informacji mieszczące się w pojęciu informacji o środowisku, które prawo Unii obejmuje systemem ujawniania informacji określonym w tej dyrektywie. W ocenie Trybunału pytanie pierwsze miało zatem przede wszystkim na celu ustalenie, czy takie informacje jak te rozpatrywane $\mathrm{w}$ postępowaniu przed sądem krajowym zaliczają się do jednej z tych kategorii.

W tym względzie Trybunał zauważył, że w spornej decyzji odmówiono ujawnienia badań na temat pozostałości i protokołów prób polowych przekazanych $\mathrm{w}$ ramach postępowania w sprawie rozszerzenia zezwolenia na dopuszczenie do obrotu produktu, który wchodzi w zakres stosowania dyrektywy 91/414. W dyrektywie tej prawodawca Unii stwierdził między innymi jak wynika z jej motywu czwartego - że środki ochrony roślin mogą mieć także niekorzystny wpływ na produkcję roślinną oraz że ich stosowanie może stwarzać ryzyko i zagrożenie dla ludzi, zwierząt i środowiska, w szczególności jeśli te środki wprowadzono do obrotu bez poddania ich urzędowym badaniom i bez urzędowego zezwolenia na dopuszczenie ich do obrotu oraz jeżeli są one niewłaściwie stosowane ${ }^{3}$.

Zdaniem Trybunały nie można więc kwestionować tego, że informacje wskazane w spornej decyzji odnoszące się do pozostałości środka ochrony roślin na artykułach spożywczych zostały przedłożone $\mathrm{w}$ ramach postępowania $\mathrm{w}$ sprawie zezwolenia na dopuszczenie do obrotu środka, którego celem jest właśnie zapobieganie ryzykom i zagrożeniom dla ludzi, zwierząt i środowiska. Z tego powodu informacje te jako takie mogą dotyczyć - jak wynika z art. 2 pkt 1 lit. f) dyrektywy 2003/4 - stanu zdrowia ludzkiego, bezpieczeństwa, w tym ewentualnie skażenia łańcucha pokarmowego. Jednakże Trybunał zauważył jednocześnie, że zgodnie ze wspomnianym art. 2 pkt 1 lit. f) informacje 
tego rodzaju wchodzą w zakres stosowania dyrektywy 2003/4 jedynie w takim stopniu, w jakim stan elementów środowiska, o których mowa w tym art. 2 pkt 1 lit. a) lub, za pośrednictwem tych elementów, czynniki, środki lub działania, o których mowa w tymże art. 2 pkt 1 lit. b) i c), oddziałują lub mogą oddziaływać na stan zdrowia ludzkiego, bezpieczeństwo i skażenie łańcucha pokarmowego, których dotyczą wspomniane powyżej informacje. Z tych względów Trybunał uznał, że w okolicznościach sprawy C-266/09 przekazanie informacji na temat obecności pozostałości środków ochrony roślin w lub na warzywach takich jak sałata - jak w sprawie w postępowaniu przed sądem krajowym miało zatem na celu, poprzez umożliwienie sprawdzenia poziomu, na jakim został ustalony maksymalny poziom pozostałości, ograniczenie ryzyka zmiany jednego ze składników biologicznej różnorodności i ryzyka rozprzestrzenienia się tych pozostałości w szczególności w glebie i w wodach gruntowych. Tego rodzaju informacje, mimo że nie zawierają one bezpośrednio oceny skutków tych pozostałości dla zdrowia ludzkiego, dotyczą elementów środowiska, które wiążą się z ryzykiem zmiany zdrowia ludzkiego w przypadku nadmiernej obecności tych pozostałości, co właśnie ma zostać sprawdzone na podstawie tych informacji ${ }^{4}$.

W drugim pytaniu sąd krajowy, w ocenie Trybunału, zmierzał zasadniczo do ustalenia, czy art. 14 dyrektywy 91/414 powinien być interpretowany w ten sposób, że może być on stosowany tylko wtedy, gdy wskutek tego stosowania nie zostaną naruszone obowiązki wynikające z art. 4 ust. 2 dyrektywy 2003/4. Trybunał wskazał, że w art. 14 dyrektywy 91/414 została ustanowiona zasada, zgodnie z którą podmioty składające wniosek o wydanie zezwolenia na dopuszczenie do obrotu mogą zażądać, by dostarczone przez nie informacje zawierające tajemnicę przemysłową lub handlową były traktowane jako poufne, jednakże „bez uszczerbku dla przepisów dyrektywy 90/313”. Artykuł 3 tej ostatniej dyrektywy przewidywał, że państwa członkowskie mogą odmówić dostępu do informacji dotyczących środowiska, jeżeli dotyczą one tajemnicy handlowej lub przemysłowej. Stąd też

\footnotetext{
4 Sprawa C-266/09, par. 39-40, 42.
} 
zdaniem Trybunału, tenże art. 14 powinien być rozumiany w ten sposób, że bez uszczerbku dla przepisów dyrektywy 2003/4 państwa członkowskie i Komisja zapewniają, że informacje dostarczone przez podmioty składające wniosek o wydanie zezwolenia na dopuszczenie do obrotu zawierające tajemnicę przemysłową lub handlową są traktowane jako poufne, jeżeli ci wnioskodawcy wystąpią z takim żądaniem oraz jeżeli państwo członkowskie lub Komisja uznają takie żądanie za uzasadnione ${ }^{5}$.

Biorąc powyższe pod uwagę, Trybunał stwierdził, że w takiej sytuacji jak ta w postępowaniu przed sądem krajowym do właściwych organów danego państwa członkowskiego, do których wpłynął wniosek o zachowanie poufności dostarczonych danych, należy rozpoznanie tego wniosku w poszanowaniu warunków przewidzianych w art. 14 dyrektywy 91/414, z zastrzeżeniem, że rozpoznanie tegoż wniosku nie może prowadzić do tego, iż dane organy, w przypadku gdy wpłynął do nich także wniosek o udostępnienie tych samych informacji, naruszą obowiązki, które obecnie na nich ciążą na podstawie dyrektywy 2003/4. Obowiązki te wynikają z przepisów art. 4 dyrektywy 2003/4. Zgodnie $\mathrm{z}$ tymi przepisami państwa członkowskie mogą przewidzieć, że wniosek o udostępnienie informacji o środowisku, chyba że informacje te dotyczą emisji do środowiska, może zostać odrzucony, jeśli ujawnienie takich informacji wpłynie negatywnie na poufność informacji handlowych lub przemysłowych, w przypadku gdy poufność ta jest przewidziana w prawie krajowym lub w prawie Unii. Tymczasem wymagają one również, by taka podstawa do odmowy była interpretowana zawężająco, z uwzględnieniem interesu, jaki dla społeczeństwa miałoby ujawnienie informacji, oraz by w każdym konkretnym przypadku interes publiczny $\mathrm{w}$ ujawnieniu danych informacji był porównywany z interesem dyktującym odmowę ich udostępnienia. W tych okolicznościach, w przypadku gdy do właściwych organów wpłynie wniosek o udostępnienie informacji o środowisku - które zostały dostarczone przez podmiot składający wniosek o wydanie zezwolenia na dopuszczenie do obrotu środków ochrony roślin i w przypad- 
ku których wniosek o ochronę jako tajemnicy przemysłowej lub handlowej w rozumieniu art. 14 dyrektywy 91/414 wydaje się im uzasadniony - organy te są jednak zobowiązane przychylić się do wniosku o udostępnienie tych informacji, jeżeli dotyczą one emisji do środowiska lub jeżeli w innych przypadkach interes publiczny w ujawnieniu danych informacji przeważa nad interesem dyktującym odmowę ich udostępnienia ${ }^{6}$.

Analizując trzecie pytanie sądu krajowego, Trybunał uznał, że sąd ten zmierzał zasadniczo do ustalenia, czy art. 4 dyrektywy 2003/4 powinien być interpretowany w ten sposób, że nakazane w nim porównanie interesu publicznego, któremu ma służyć ujawnienie informacji o środowisku, z interesem szczególnym dyktującym odmowę udostępnienia informacji powinno odbyć się w każdym konkretnym przypadku przedłożonym właściwym organom czy też może zostać określone w środku o charakterze generalnym wydanym przez prawodawcę krajowego. W tym względzie Trybunał stwierdził, że z samego brzmienia art. 4 dyrektywy 2003/4 wynika, że prawodawca Unii przewidział, iż wyważenie istniejących interesów musi być dokonane w każdym konkretnym przypadku. Ani przepisy art. 14 dyrektywy 91/414, ani żaden inny przepis dyrektywy 2003/4 nie pozwalają uznać, że wyważenie istniejących interesów, które zostało nakazane w art. 4 dyrektywy 2003/4, może zostać zastąpione innym środkiem niż badanie tych interesów w każdym konkretnym przypadku. W każdym razie powyższa okoliczność nie stoi na przeszkodzie, by prawodawca krajowy określił w przepisie o charakterze generalnym kryteria umożliwiające ułatwienie tej porównawczej oceny istniejących interesów, pod warunkiem jednak że ten przepis nie zwalnia właściwych organów z rzeczywistego przeprowadzenia konkretnego badania danej sytuacji, która zostaje im przedłożona w ramach wniosku o udostępnienie informacji o środowisku złożonego na podstawie dyrektywy 2003/47.

6 Sprawa C-266/09, par. 51-53.

Sprawa C-266/09, par. 55-58. 


\section{II.2. WYROK TRYBUNAEU Z DNIA 22 GRUDNIA 2010 R. W SPRAWIE C-524/09 VILLE DE LYON PRZECIWKO CAISSE DES DÉPÔTS ET CONSIGNATIONS ${ }^{8}$}

1) Udostępnienie danych transakcyjnych takich jak te, o których mowa w postępowaniu przed sądem krajowym, dotyczących posiadaczy rachunków, z których i na które przenoszone są uprawnienia do emisji, uprawnień lub jednostek Kioto objętych tymi transakcjami, jak również daty i godziny tych transakcji, podlega wyłącznie szczególnym regułom publicznego udostępniania i poufności zawartym w dyrektywie 2003/87/WE Parlamentu Europejskiego i Rady z dnia 13 października 2003 r. ustanawiającej system handlu przydziałami [uprawnieniami do] emisji gazów cieplarnianych we Wspólnocie oraz zmieniającej dyrektywę Rady 96/61/WE', w jej brzmieniu wynikającym z dyrektywy 2004/101/WE Parlamentu Europejskiego i Rady z dnia 27 października 2004 r. $^{10}$, oraz regułom zawartym w rozporządzeniu Komisji (WE) nr 2216/2004 z dnia 21 grudnia 2004 r. w sprawie standaryzowanego i zabezpieczonego systemu rejestrów stosownie do dyrektywy 2003/87/WE Parlamentu Europejskiego i Rady oraz decyzji nr 280/2004/WE Parlamentu Europejskiego i Rady ${ }^{11}$.

2) Dane transakcyjne takie jak te, których udostępnienia dochodzi $w$ postępowaniu przed sądem krajowym jednostka samorządu terytorialnego zamierzająca renegocjować umowę dzierżawy, stanowią dane poufne

8 http://curia.eu; dalej cyt.: sprawa C-524/09.

9 Dz. Urz. UE L 275 z 25.10.2003, s. 32-46 ze zm.

10 Dyrektywa 2004/101/WE Parlamentu Europejskiego i Rady z dnia 27 października 2004 r. zmieniająca dyrektywę 2003/87/WE ustanawiającą system handlu przydziałami emisji gazów cieplarnianych we Wspólnocie, z uwzględnieniem mechanizmów projektowych Protokołu z Kioto, Dz. Urz. UE

11 Dz. Urz. UE L 386 z 29.12.2004, s. 1-77. 
w rozumieniu rozporządzenia nr 2216/2004 i zgodnie z art. 9 i 10 w związku z pkt 11 i 12 załącznika XVI do tego rozporządzenia $w$ braku uprzedniej zgody danych posiadaczy rachunków dane takie są swobodnie dostępne ogółowi społeczeństwa wyłącznie w obszarze publicznym strony WWW niezależnego dziennika transakcji Wspólnoty od dnia 15 stycznia piątego roku $(X+5)$ po roku $(X)$ dokonania transakcji dotyczących przeniesienia uprawnień do emisji.

3) Dla celów wykonania rozporządzenia nr 2216/2004 jedynie centralny administrator jest uprawniony do udostępnienia ogółowi społeczeństwa danych, o których mowa w pkt 12 załącznika XVI do tego rozporządzenia, niemniej administrator rejestru krajowego, do którego złożono wniosek o udostępnienie takich danych transakcyjnych, musi sam odrzucić ten wniosek, gdyż w braku uprzedniej zgody danych posiadaczy rachunków administrator ten jest zobowiązany zapewnić poufność tych danych dopóty, dopóki nie mogą one zostać udostępnione zgodnie $\mathrm{z}$ prawem ogółowi społeczeństwa przez centralnego administratora.

Wniosek o wydanie orzeczenia w trybie prejudycjalnym został złożony przez tribunal administratif de Paris (Francja) w ramach sporu między miastem Lyon a Caisse des dépôts et consignations (kasą depozytową, zwaną dalej „CDC”) w przedmiocie odmowy udzielenia przez nią tej jednostce samorządu terytorialnego danych dotyczących ilości uprawnień do emisji gazów cieplarnianych sprzedanych w roku 2005 przez niektórych operatorów.

W dniu 7 lutego 2006 r. miasto Lyon zwróciło się do CDC o przekazanie mu danych na temat z jednej strony ilości uprawnień do emisji gazów cieplarnianych sprzedanych w 2005 r. przez operatorów każdej z 209 ciepłowni miejskich, którym przyznano uprawnienia do emisji, a z drugiej strony dat transakcji oraz odbiorców (zwanych dalej łącznie „danymi transakcyjnymi”). Władze miasta Lyon uważały, że dane te były miastu potrzebne do celów porównawczych w ramach renegocjacji umowy dzierżawy ciepłowni miejskiej La Duchère, położonej w aglomeracji lioń- 
skiej. Decyzją z dnia 6 marca 2006 r. CDC odmówiła przekazania tych danych, uzasadniając, że stoją temu na przeszkodzie art. 10 rozporządzenia nr 2216/2004 oraz pkt 11 i 12 załącznika XVI do tego rozporządzenia ${ }^{12}$.

Trybunał rozpoczął swoją analizę od pytania drugiego, w ramach którego sąd krajowy zwrócił się o wyjaśnienie, czy udostępnienie danych transakcyjnych takich jak te, których udostępnienia $\mathrm{w}$ postępowaniu przed sądem krajowym dochodzi miasto Lyon, regulowane jest jednym $\mathrm{z}$ wyjątków przewidzianych w art. 4 dyrektywy 2003/4 czy przez przepisy dyrektywy 2003/87 i rozporządzenia nr 2216/2004 przyjętego w wykonaniu tej dyrektywy. W pierwszej kolejności Trybunał zaznaczył, że w związku z systemem handlu uprawnieniami do emisji wprowadzonego w dyrektywie 2003/87 art. 17 tej dyrektywy przewiduje między innymi, iż decyzje odnoszące się do rozdzielania uprawnień operatorom instalacji uprawnionych do emisji gazów cieplarnianych oraz sprawozdania dotyczące emisji wymagane zgodnie z pozwoleniem na emisje gazów cieplarnianych, które znajdują się w posiadaniu właściwego organu, są podawane do publicznej wiadomości zgodnie z dyrektywą 2003/4/WE. W ocenie Trybunału, o ile prawodawca unijny wprowadził $\mathrm{w}$ ten sposób w ramach dyrektywy 2003/87 przepisy dotyczące publicznego dostępu do tego rodzaju informacji, o tyle nie zamierzał on jednak objąć przepisami dyrektywy 2003/4 udostępniania wszelkich informacji lub danych mających związek z wykonaniem dyrektywy $2003 / 87^{13}$.

Dane transakcyjne, o które zwróciło się miasto Lyon, nie są zdaniem Trybunału, objęte art. 17 dyrektywy 2003/87, który odsyła do dyrektywy 2003/4. Chodzi tu natomiast o dane, o których mowa w art. 19 dyrektywy 2003/87, to znaczy dane dotyczące przeniesionych uprawnień, które muszą być dokładnie księgowane przez państwa członkowskie w ich rejestrach krajowych. Szczegóły techniczne i reguły prowadzenia tych rejestrów oraz udostępniania i poufności zawartych w nich danych określa rozporządzenie nr 2216/2004. Ze względu na to, że art. 19

13 Sprawa C-524/09, par. 34, 37-38. 
dyrektywy 2003/87 nie odsyła do dyrektywy 2003/4, jak czyni to wspomniany art. 17, należy uznać, że prawodawca Unii nie zamierzał poddać wniosku dotyczącego danych transakcyjnych takich jak te, których dotyczy postępowanie przed sądem krajowym, ogólnym przepisom dyrektywy 2003/4, lecz że wręcz przeciwnie w odniesieniu do tych danych ustanowił szczególny i wyczerpujący system ich publicznego udostępniania jak również ich poufności. Mając powyższe na uwadze Trybunał na pytanie drugie odpowiedział, że wniosek o udostępnienie danych transakcyjnych takich jak te, o których mowa w postępowaniu przed sądem krajowym, dotyczących posiadaczy rachunków, z których i na które przenoszone są uprawnienia do emisji, uprawnień lub jednostek Kioto objętych tymi transakcjami, jak również daty i godziny tych transakcji, podlega wyłącznie szczególnym regułom publicznego udostępniania i poufności zawartym w dyrektywie 2003/87 i w rozporządzeniu $\mathrm{nr} 2216 / 2004^{14}$.

Trybunał stwierdził, że $\mathrm{w}$ pytaniach trzecim i czwartym, które należało rozpatrzyć łącznie, sąd krajowy zmierzał do wyjaśnienia z jednej strony, czy udostępnienie danych transakcyjnych takich jak te, których dotyczy postępowanie przed sądem krajowym, podlega szczególnym regułom poufności przewidzianym w art. 9 i 10 rozporządzenia nr 2216/2004, a z drugiej strony, czy ujawnienia danych transakcyjnych dotyczących wszystkich zrealizowanych transakcji, o których mowa w pkt 11 i 12 załącznika XVI do tego rozporządzenia, należy dokonać po upływie okresu pięciu lat od dokonania danej transakcji, czy też chodzi o ujawnienie informacji dotyczących wszystkich transakcji dokonanych $\mathrm{w}$ pięcioletnim okresie rozdzielania uprawnień $\mathrm{w}$ rozumieniu dyrektywy 2003/87, które powinno mieć miejsce po upływie tego okresu. Na wypadek gdyby to ujawnienie miało nastąpić po upływie pięcioletniego okresu od dokonania danej transakcji, sąd krajowy chciał wiedzieć, czy można uznać, że renegocjacje umowy dzierżawy, o których mowa w postępowaniu przed sądem krajowym, zmierzają do wypełnienia wymogów rozporządzenia nr 2216/2004, dyrektywy 2003/87 lub przepisów prawa

\footnotetext{
14 Sprawa C-524/09, par. 39-41.
} 
krajowego zgodnie z art. 10 ust. 1 tego rozporządzenia, co mogłoby powodować, iż nie można by odmówić udostępnienia żądanych danych transakcyjnych ze względu na ich poufność ${ }^{15}$.

W ocenie Trybunału, z art. 9 rozporządzenia nr 2216/2004 wynika, że administratorzy rejestrów krajowych tacy jak CDC we Francji, jak też centralny administrator wyznaczony przez Komisję, udostępniają odbiorcom wymienionym w załączniku XVI informacje wskazane w tym załączniku z określoną w nim częstotliwością w sposób przejrzysty i zorganizowany poprzez swoje strony internetowe lub poprzez stronę internetową niezależnego dziennika transakcji Wspólnoty. Zgodnie natomiast z art. 10 ust. 1 rozporządzenia nr 2216/2004 wszystkie informacje, w tym dane dotyczące dokonanych transakcji, przechowywane we wszystkich rejestrach, uważane są za poufne w odniesieniu do wszelkich innych celów niż wypełnienie wymogów tego rozporządzenia, dyrektywy 2003/87/WE lub przepisów krajowego prawa. Ponadto zgodnie z ust. 2 tego artykułu informacje te nie mogą być wykorzystywane bez uprzedniej zgody danego posiadacza rachunku inaczej niż do obsługi i utrzymania tych rejestrów zgodnie z przepisami niniejszego rozporządzenia ${ }^{16}$.

Trybunał stanął na stanowisku, że renegocjacje umowy dzierżawy przez jednostkę samorządu terytorialnego taką jak miasto Lyon nie stanowią co do zasady wypełnienia wymogów rozporządzenia nr 2216/2004, dyrektywy 2003/87 lub przepisów prawa krajowego. Miasto Lyon nie jest przy tym posiadaczem rachunku i w konsekwencji nie ma dostępu na warunkach określonych w pkt 13 i 14 załącznika XVI do rozporządzenia nr 2216/2004 do informacji, które mogą być umieszczane w niepublicznym obszarze rejestru krajowego na ewentualny wniosek ciepłowni miejskich, o których mowa w postępowaniu przed sądem krajowym. Mając powyższe na uwadze Trybunał uznał, że w okolicznościach takich jak w sprawie przed sądem krajowym, a w każdym razie w braku wymaganej w art. 10 ust. 2 rozporządzenia nr 2216/2004 uprzedniej zgody danego posiadacza rachunku na wykorzystanie dotyczących go informacji do ce- 
lów innych niż do obsługi i prowadzenia rejestrów, informacje takie jak dane transakcyjne, o których mowa w postępowaniu przed sądem krajowym, powinny zostać poufne, wobec czego miasto Lyon może domagać się wyłącznie dostępu do informacji dotyczących transakcji obejmujących uprawnienia do emisji na warunkach określonych dla ogółu społeczeństwa, to znaczy w drodze swobodnej konsultacji zgodnie z pkt 5 i 6 załącznika XV do rozporządzenia nr 2216/2004 publicznego obszaru strony WWW niezależnego dziennika transakcji Wspólnoty oraz publicznego obszaru strony WWW rejestrów krajowych, które są wyodrębnione od baz danych tego dziennika i tych rejestrów ${ }^{17}$.

W ocenie Trybunału, w pierwszym pytaniu sąd krajowy zmierzał do ustalenia, czy administrator rejestru krajowego, przez którego przechodzą dane takie jak te, o których mowa w postępowaniu przed sądem krajowym i których udostępnienie należy do kompetencji centralnego administratora, w przypadku złożenia do niego odpowiedniego wniosku może sam odmówić ich udostępnienia. Zdaniem Trybunału, w systemie przewidzianym w rozporządzeniu nr 2216/2004, a w szczególności w pkt 11 i 12 załącznika XVI do tego rozporządzenia, przewidziano wyraźnie, że dane dotyczące posiadaczy rachunków, z których i na które przenoszone są uprawnienia do emisji, uprawnień lub jednostek Kioto objętych tymi transakcjami, jak również daty i godziny tych transakcji, są udostępniane ogółowi społeczeństwa poprzez umieszczenie w publicznym obszarze strony WWW niezależnego dziennika transakcji Wspólnoty i że w tym kontekście jedynie centralny administrator jest właściwy do ich udostępnienia. Umieszczenie w Internecie następuje od dnia 15 stycznia piątego roku $(\mathrm{X}+5)$ po roku $(\mathrm{X})$ dokonania transakcji przeniesienia uprawnień do emisji, z którym to dniem dane transakcyjne przestają być objęte systemem poufności wprowadzonym przez prawodawcę unijnego. W konsekwencji Trybunał stwierdził, że jeżeli wniosek skierowany do administratora rejestru krajowego dotyczy udostępnienia informacji odnoszących się do mających siedzibę na terytorium kraju tego administratora posiadaczy ra-

17 Sprawa C-524/09, par. 48-50. 
chunków, z których i na które przenoszone są uprawnienia do emisji, do uprawnień lub jednostek Kioto objętych tymi transakcjami, jak również do daty i godziny tych transakcji, administrator ten w braku uprzedniej zgody danych posiadaczy rachunków jest zobowiązany zapewnić poufność takich informacji dopóty, dopóki nie mogą one zostać udostępnione zgodnie z prawem ogółowi społeczeństwa przez centralnego administratora. W takiej sytuacji administrator rejestru krajowego musi sam odrzucić skierowany do niego w ten sposób wniosek o udostępnienie informacji. Jeżeli natomiast informacje te zostały już umieszczone zgodnie z pkt 11 i 12 załącznika XVI do rozporządzenia nr 2216/2004 przez centralnego administratora w publicznym obszarze strony WWW niezależnego dziennika transakcji Wspólnoty, administrator rejestru krajowego jest uprawniony do udostępnienia wnioskodawcy takich informacji lub wskazania mu strony WWW, na której informacje te są legalnie dostępne ${ }^{18}$.

\section{II.3. WYROK TRYBUNALU Z DNIA 28 LIPCA 2011 R. W SPRAWIE C-71/10 OFFICE OF COMMUNICATIONS PRZECIWKO INFORMATION COMMISSIONER ${ }^{19}$}

Artykuł 4 ust. 2 dyrektywy 2003/4/WE Parlamentu i Rady z dnia 28 stycznia 2003 r. w sprawie publicznego dostępu do informacji dotyczących środowiska i uchylającej dyrektywę Rady 90/313/EWG ${ }^{20}$ należy interpretować w ten sposób, że w sytuacji gdy organ władzy publicznej znajduje się $\mathrm{w}$ posiadaniu informacji o środowisku lub gdy takie informacje są dla niego przeznaczone, może on - w ramach porównywania publicznego interesu ujawnienia informacji $\mathrm{z}$ interesem dyktującym odmowę ich udostępnienia $\mathrm{w}$ celu oceny wniosku zmierzającego do udostępnienia takich informacji osobie fizycznej lub prawnej - uwzględnić kumulatywnie kilka przyczyn odmowy wskazanych w tym przepisie.

Sprawa C-524/09, par. 54-58.

19 http://curia.eu; dalej cyt.: sprawa C-71/10.

20 Dz. Urz. UE L 41 z 14.2.2003, s. 26-32. 
W sprawie C-71/10 wniosek o wydanie orzeczenia w trybie prejudycjalnym dotyczy wykładni art. 4 dyrektywy 2003/4/WE Parlamentu Europejskiego i Rady z dnia 28 stycznia 2003 r. w sprawie publicznego dostępu do informacji dotyczących środowiska i uchylającej dyrektywę Rady 90/313/EWG został złożony w ramach sporu pomiędzy Office of Communications a Information Commissioner w przedmiocie wniosku o udzielenie informacji dotyczących dokładnego położenia stacji bazowych telefonii komórkowej w Zjednoczonym Królestwie.

W ocenie Trybunału pytanie sądu krajowego zmierzało do ustalenia, czy w sytuacji gdy organ władzy publicznej znajduje się $\mathrm{w}$ posiadaniu informacji o środowisku lub gdy takie informacje są dla niego przeznaczone, może on - po wyważeniu interesów publicznych, jakim służy ujawnienie, i interesów, jakim służy odmowa ujawnienia - w celu oceny wniosku zmierzającego do udostępnienia takich informacji osobie fizycznej lub prawnej, uwzględnić kumulatywnie kilka przyczyn odmowy wskazanych w art. 4 ust. 2 dyrektywy 2003/4, czy też powinien on rozważyć te interesy, analizując odrębnie każdy z nich.

Na kanwie sprawy C-71/10 Trybunał przypomniał, że jak wynika z systematyki dyrektywy 2003/4, a w szczególności $\mathrm{z}$ art. 4 ust. 2 akapit drugi tego aktu, a także z motywu 16, prawo do informacji oznacza, że ujawnianie informacji powinno stanowić regułę oraz że organy władzy publicznej powinny móc odmówić udostępnienia informacji o środowisku wyłącznie w określonych i jasno sprecyzowanych przypadkach. Podstawy odmowy powinny być zatem interpretowane zawężająco, przy czym należy rozważyć, czy społeczny interes, któremu ma służyć ujawnienie informacji, nie przeważa nad interesem dyktującym odmowę udostępnienia informacji. Trybunał zaznaczył, że ze sformułowania rozpoczynającego art. 4 ust. 2 „[p]aństwa członkowskie mogą zdecydować" wynika, że wprowadzone zostaną odstępstwa od ogólnej reguły ujawniania informacji opinii publicznej. W sytuacji gdy państwo członkowskie decyduje się na wprowadzenie takich odstępstw zgodnie z tym przepisem, jego brzmienie nie narzuca szczególnej metody badania podstaw odmowy.

W myśl art. 4 ust. 2 akapit drugi zdanie drugie dyrektywy „[w] każdym przypadku publiczny interes ujawnienia informacji 
jest porównywany z interesem dyktującym odmowę ich udostępnienia". Trybunał zgodził się z rzecznik generalną, która w swojej opinii wskazała, że zdanie to pełni samodzielną funkcję, niezależną od zdania pierwszego tego samego akapitu. Zdanie pierwsze akapitu drugiego wyraża już bowiem obowiązek oceny wagi każdej z podstaw odmowy w świetle interesu, jaki stanowi dla społeczeństwa ujawnienie informacji. Jeżeli określenie tego obowiązku miałoby być jedynym celem omawianego zdania drugiego, to zdanie to byłoby niepotrzebnym i zbytecznym powtórzeniem myśli wyrażonej w zdaniu pierwszym tego akapitu. Ponadto, jak zaznaczył Trybunał, podczas wyważania wchodzących w grę interesów, kilka odrębnych interesów może kumulatywnie przemawiać za ujawnieniem informacji.

Zdaniem Trybunału pojęcie „publiczny interes ujawnienia” zawarte w art. 4 ust. 2 akapit drugi zdanie drugie dyrektywy należy uznać za pojęcie ogólne, obejmujące szereg względów uzasadniających ujawnienie informacji o środowisku. Stąd też celem art. 4 ust. 2 akapit drugi zdanie drugie dyrektywy jest porównanie dwóch pojęć ogólnych, co umożliwia właściwym władzom publicznym ocenę kumulatywnych podstaw odmowy ujawnienia informacji podczas dokonywania takiego porównania. Wniosku tego nie podważa okoliczność położenia w art. 4 ust. 2 akapit drugi zdanie drugie dyrektywy nacisku na obowiązek porównania wchodzących w grę interesów „w każdym przypadku”. Akcent ten ma bowiem na celu podkreślenie, że to porównanie powinno być dokonywane nie na podstawie ogólnego przepisu przyjętego na przykład przez ustawodawcę krajowego, ale ma być wynikiem przeprowadzenia konkretnego badania danej sytuacji, która zostaje przedstawiona właściwym władzom w ramach wniosku o udostępnienie informacji o środowisku złożonego na podstawie dyrektywy 2003/4 (zob. sprawa C-266/09 Stichting Natuur en Milieu i in., dotychczas nieopublikowana, par. 55-58).

Ponadto fakt, że interesy te zostały wyodrębnione w art. 4 ust. 2 dyrektywy 2003/4 nie stoi na przeszkodzie skumulowaniu tych odstępstw od ogólnej zasady ujawniania, zwłaszcza że interesy dyktujące odmowę udostępnienia mogą niekiedy nakładać się na siebie w danej sytuacji lub konkretnym wypadku. Należy 3/2011 jeszcze podkreślić, iż ponieważ poszczególne interesy dyktujące 
odmowę udostępnienia informacji powiązane są, tak jak w sprawie przed sądem krajowym, z podstawami odmowy wskazanymi w art. 4 ust. 2 dyrektywy 2003/4, kumulatywne uwzględnienie tych interesów $\mathrm{w}$ ramach ich porównywania z publicznymi interesami w ujawnieniu nie może skutkować wprowadzeniem dodatkowej podstawy odmowy, która nie została wymieniona $\mathrm{w}$ tym przepisie. Jeżeli takie porównanie interesami publicznymi interesami w ujawnieniu miałoby doprowadzić do jego odmowy, to należałoby przyznać, iż owo ograniczenie dostępu do żądanych informacji jest proporcjonalne, a więc uzasadnione w świetle ogólnego interesu, na jaki składają się łącznie interesy dyktujące odmowę udostępnienia informacji ${ }^{21}$.

\section{OCHRONA WÓD}

\section{III.1. WYROK TRYBUNAEU Z DNIA 30 WRZEŚNIA 2010 R. W SPRAWIE C-481/09 KOMISJA PRZECIWKO REPUBLICE CZESKIEJ ${ }^{22}$}

Przedmiot: uchybienie zobowiązaniom państwa członkowskiego - brak przyjęcia lub poinformowania o przyjęciu w wyznaczonym terminie przepisów niezbędnych do wykonania dyrektywy 2006/7/WE Parlamentu Europejskiego i Rady z dnia 15 lutego 2006 r. dotyczącej zarządzania jakością wody w kąpieliskach i uchylającej dyrektywę 76/160/EWG.

Sentencja:

1) Nie przyjmując przepisów ustawowych, wykonawczych i administracyjnych niezbędnych do wykonania dyrektywy 2006/7/WE Parlamentu Europejskiego i Rady z dnia 15 lutego 2006 r. dotyczącej zarządzania jakością wody w kąpieliskach i uchylającej dyrektywę 76/160/EWG,

21 Sprawa 71/10, par. 21-31.

22 Dz. Urz. UE C 317 z 20.11.2010, s. 11-12; uzasadnienie wyroku dostępne jedynie w czeskiej i francuskiej wersji językowej. 
Republika Czeska uchybiła zobowiązaniom ciążącym na niej na mocy tej dyrektywy.

2) Republika Czeska zostaje obciążona kosztami postępowania.

\section{III.2. WYROK TRYBUNAEU Z DNIA 22 GRUDNIA 2010 R. W SPRAWIE C-351/09 KOMISJA EUROPEJSKA PRZECIWKO REPUBLICE MALTY ${ }^{23}$}

Przedmiot: uchybienie zobowiązaniom państwa członkowskiego - naruszenie art. 8 i 15 dyrektywy 2000/60/WE Parlamentu Europejskiego i Rady z dnia 23 października 2000 r. ustanawiającej ramy wspólnotowego działania w dziedzinie polityki wodnej - obowiązek stworzenia i uruchomienia programów monitorowania stanu wód powierzchniowych - obowiązek przedstawienia podsumowujących sprawozdań z programów monitorowania wód powierzchniowych.

Sentencja:

1) Po pierwsze nie tworząc programów monitorowania stanu śródlądowych wód powierzchniowych oraz nie uruchamiając ich zgodnie $z$ art. 8 ust. 1 i 2 dyrektywy 2000/60/WE Parlamentu Europejskiego i Rady z dnia 23 października 2000 r. ustanawiającej ramy wspólnotowego działania w dziedzinie polityki wodnej, a po drugie nie przedstawiając podsumowujących sprawozdań z programów monitorowania stanu śródlądowych wód powierzchniowych zgodnie z art. 15 ust. 2 tej dyrektywy, Republika Malty uchybiła zobowiązaniom, które na niej ciążą na mocy art. 8 i 15 tej dyrektywy.

2) Republika Malty zostaje obciążona kosztami postępowania.

23 Dz. Urz. UE C 063 z 26.02.2011, s. 7-8; uzasadnienie wyroku dostępne jedynie w angielskiej i francuskiej wersji językowej. 


\section{III.3. WYROK TRYBUNAŁU Z DNIA 22 GRUDNIA 2010 R. W SPRAWIE C-276/10 KOMISJA EUROPEJSKA PRZECIWKO REPUBLICE CZESKIEJ ${ }^{24}$}

Przedmiot: uchybienie zobowiązaniom państwa członkowskiego - brak przyjęcia lub powiadomienia Komisji w wyznaczonym terminie o przyjęciu przepisów ustawowych, wykonawczych i administracyjnych niezbędnych do dokonania transpozycji dyrektywy 2006/118/WE Parlamentu Europejskiego i Rady z dnia 12 grudnia $2006 \mathrm{r}$. w sprawie ochrony wód podziemnych przed zanieczyszczeniem i pogorszeniem ich stanu.

Sentencja:

1) Nie przyjmując $w$ wyznaczonym terminie przepisów ustawowych, wykonawczych i administracyjnych niezbędnych do dokonania transpozycji dyrektywy 2006/118/WE Parlamentu Europejskiego i Rady z dnia 12 grudnia 2006 r. w sprawie ochrony wód podziemnych przed zanieczyszczeniem i pogorszeniem ich stanu, Republika Czeska uchybiła zobowiązaniom ciążącym na niej na mocy art. 12 tej dyrektywy.

2) Republika Czeska zostaje obciążona kosztami postępowania.

\section{III.4. WYROK TRYBUNAEU Z DNIA 9 CZERWCA 2011 R. \\ W SPRAWIE C-458/10 KOMISJA EUROPEJSKA \\ PRZECIWKO WIELKIEMU KSIĘSTWU LUKSEMBURGA ${ }^{25}$}

Przedmiot: uchybienie zobowiązaniom państwa członkowskiego - niepełna i nieprawidłowa transpozycja art. 9 ust. 3 lit. b), c) i e) dyrektywy Rady 98/83/WE z dnia 3 listopada 1998 r. w sprawie jakości wody przeznaczonej do spożycia przez

24 Dz. Urz. UE C 063 z 26.02.2011, s. 12; uzasadnienie wyroku dostępne jedynie w czeskiej i francuskiej wersji językowej.

25 Dz. Urz. UE C 226 z 30.07.2011, s. 8-9; uzasadnienie wyroku dostępne jedynie we francuskiej wersji językowej. 
ludzi - dystrybucja wody pitnej nieodpowiadającej wymaganym wartościom parametrycznym - system odstępstw

Sentencja:

1) Nie dokonując pełnej i prawidłowej transpozycji art. 9 ust. 3 lit. b), c) i e) dyrektywy Rady 98/83/WE z dnia 3 listopada 1998 r. w sprawie jakości wody przeznaczonej do spożycia przez ludzi, Wielkie Księstwo Luksemburga uchybiło zobowiązaniom, jakie ciążą na nim na mocy tej dyrektywy.

2) Wielkie Księstwo Luksemburga zostaje obciążone kosztami postępowania.

\section{OCHRONA POWIETRZA}

\section{WYROK TRYBUNAŁU Z DNIA 26 MAJA 2011 R. W POŁĄCZONYCH \\ SPRAWACH C-165/09 DO C-167/09 STICHTING NATUUR EN MILIEU \\ I INNI PRZECIWKO COLLEGE VAN GEDEPUTEERDE STATEN \\ VAN GRONINGEN (C-165/09) I COLLEGE VAN GEDEPUTEERDE STATEN VAN ZUID-HOLLAND (C-166/09 I C-167/09) ${ }^{26}$}

1) Artykuł 9 ust. 1, 3 i 4 dyrektywy Rady 96/61/WE z dnia 24 września 1996 r. dotyczącej zintegrowanego zapobiegania zanieczyszczeniom i ich kontroli, w jej wersji pierwotnej jak też w wersji skodyfikowanej przez dyrektywę Parlamentu Europejskiego i Rady 2008/1/WE z dnia 15 stycznia 2008 r. dotyczącą zintegrowanego zapobiegania zanieczyszczeniom i ich kontroli ${ }^{27}$, należy interpretować $w$ ten sposób, iż wydając pozwolenie środowiskowe na budowę i eksploatację instalacji przemysłowej takiej jak te, których dotyczą sprawy przed sądem krajowym, państwa członkowskiego nie

26 http://curia.eu; dalej cyt.: sprawy C-165 do167/09.

27 Dz. Urz. UE L 24 z 29.1.2008, s. 8-29; dalej cyt.: dyrektywa IPPC.

PRIEELĄ PRAWA OCHRONY ŚRODOWISWA 
są zobowiązane do zaliczenia do warunków wydania tego pozwolenia krajowych poziomów emisji SO2 i NOx ustalonych w dyrektywie 2001/81/WE Parlamentu Europejskiego i Rady z dnia 23 października 2001 r. w sprawie krajowych poziomów emisji dla niektórych rodzajów zanieczyszczenia powietrza ${ }^{28}$, przestrzegając jednak wynikającego z dyrektywy 2001/81 obowiązku przyjęcia lub zaplanowania, w ramach programów krajowych, działań politycznych oraz odpowiednich i spójnych środków, które ogółem umożliwią redukcję emisji w szczególności tych zanieczyszczeń do ilości nieprzekraczających najpóźniej na koniec roku 2010 poziomów wskazanych w załączniku I do tej dyrektywy.

2) W okresie przejściowym od 27 listopada 2002 r. do 31 grudnia 2010 r., przewidzianym w art. 4 dyrektywy 2001/81,

- art. 4 ust. 3 TUE $i$ art. 288 akapit trzeci TFUE oraz dyrektywa 2001/81 wymagają, by państwa członkowskie powstrzymały się od przyjmowania przepisów, które mogą poważnie zagrażać osiągnięciu celu wyznaczonego w tej dyrektywie;

- samo przyjęcie przez państwa członkowskie szczególnego środka dotyczącego jednego źródła SO2 i NOx nie może poważnie zagrozić celowi wyznaczonemu w dyrektywie 2001/81. Do sądu krajowego należy zweryfikowanie, czy ma to miejsce w wypadku każdej z decyzji o wydaniu pozwolenia środowiskowego na budowę i eksploatację instalacji przemysłowej, takiej jak te, których dotyczą sprawy przed sądem krajowym;

- art. 288 akapit trzeci TFUE oraz art. 6, art. 7 ust. 1 i 2 i art. 8 ust. 1 i 2 dyrektywy 2001/81 nakładają na państwa członkowskie z jednej strony wymóg opracowania, aktualizacji i w razie potrzeby rewizji krajowych programów stopniowej redukcji emisji SO2

28 Dz. Urz. UE L 309 z 27.11.2001, s. 22-30; dalej cyt.: dyrektywa NEC. 
i NOx, które zobowiązane są podać do wiadomości publicznej i odpowiednich organizacji w jasny, zrozumiały i łatwo dostępny sposób, jak też przekazać Komisji w wyznaczonych terminach, a z drugiej strony wymóg sporządzenia i corocznego aktualizowania krajowych inwentaryzacji emisji wspomnianych zanieczyszczeń oraz prognoz krajowych na 2010 r., które w wyznaczonych terminach należy przekazywać Komisji i Europejskiej Agencji Ochrony Środowiska; - art. 288 akapit trzeci TFUE i sama dyrektywa 2001/81 nie wymagają od państw członkowskich ani odmowy bądź ograniczenia wydania pozwolenia środowiskowego, takiego jak pozwolenia będące przedmiotem spraw przed sądem krajowym, ani przyjęcia szczególnych środków wyrównawczych dla każdego wydanego pozwolenia tego rodzaju, nawet w wypadku przekroczenia lub ryzyka przekroczenia krajowych poziomów emisji SO2 i NOx.

3) Artykuł 4 dyrektywy 2001/81 nie jest bezwarunkowy i wystarczająco precyzyjny, aby jednostki mogły powoływać się na niego przed sądami krajowymi przed dniem 31 grudnia $2010 \mathrm{r}$.

Artykuł 6 dyrektywy 2001/81 przyznaje bezpośrednio zainteresowanym jednostkom prawa, na które można się powołać przed sądami krajowymi w uzasadnieniu żądania, by w okresie przejściowym od 27 listopada 2002 r. do 31 grudnia 2010 r. państwa członkowskie przyjęły lub zaplanowały, $\mathrm{w}$ ramach programów krajowych, działania polityczne oraz odpowiednie i spójne środki, które w swej całości umożliwią redukcję emisji wskazanych zanieczyszczeń, tak aby dostosować się do krajowych poziomów przewidzianych w załączniku I do tej dyrektywy najpóźniej na koniec roku 2010, oraz by podały opracowane $\mathrm{w}$ tym celu programy do wiadomości publicznej i odpowiednich organizacji w jasny, zrozumiały i łatwo dostępny sposób.

Wnioski o wydanie orzeczenia prejudycjalnego dotyczyły wykładni art. 9 dyrektywy Rady 96/61/WE z dnia 24 września 
1996 r. dotyczącej zintegrowanego zapobiegania zanieczyszczeniom i ich kontroli w jej wersji pierwotnej, jak też w wersji skodyfikowanej przez dyrektywę Parlamentu Europejskiego i Rady 2008/1/WE z dnia 15 stycznia 2008 r. dotyczącą zintegrowanego zapobiegania zanieczyszczeniom i ich kontroli, oraz właściwych w odniesieniu do okoliczności faktycznych sporów przed sądem krajowym przepisów dyrektywy 2001/81/WE Parlamentu Europejskiego i Rady z dnia 23 października 2001 r. w sprawie krajowych poziomów emisji dla niektórych rodzajów zanieczyszczenia powietrza $^{29}$.

W sprawie C-165/09 wniosek sądu krajowego - Raad van State (Holandia) - dotyczył sporów między fundacjami Stichting Natuur en Milieu i Stichting Greenpeace Nederland oraz czterema osobami fizycznymi, a College van Gedeputeerde Staten van Groningen (rządem prowincji Groningen) w przedmiocie decyzji, w drodze której ten ostatni wydał spółce RWE Power AG pozwolenie na budowę i eksploatację elektrowni na terytorium prowincji Groningen. Z kolei wniosek w sprawach C-166/09 i C-167/09 dotyczył sporów między fundacjami Natuur en Milieu, Stichting Zuid-Hollandse Milieufederatie, Greenpeace oraz stowarzyszeniem Vereniging van Verontruste Burgers van Voorne (stowarzyszenie mieszkańców Voorne zaniepokojonych zanieczyszczeniami) a College van Gedeputeerde Staten van Zuid-Holland (rządem prowincji Holandii Południowej) w przedmiocie decyzji, w drodze których władze te wydały odpowiednio spółkom Electrabel Nederland N.V. i E.On Benelux N.V. pozwolenia na budowę i eksploatację dwóch elektrowni na terytorium prowincji Holandii Południowej ${ }^{30}$.

Trybunał przyjął, że poprzez swoje pytanie pierwsze Raad van State zwrócił się o ustalenie, czy art. 9 ust. 1, 3 i 4 dyrektywy IPPC należy interpretować w ten sposób, że wydając pozwolenie środowiskowe na budowę i eksploatację instalacji przemysłowej, właściwe władze krajowe są zobowiązane uwzględnić w warunkach wydania tego pozwolenia krajowe poziomy emisji SO2

29 Sprawy C-165 do167/09, par. 1.

30 Sprawy C-165 do167/09, par. 2. 
i NOx ustalone w dyrektywie NEC. Na wstępie Trybunał wskazał, że w jego ocenie żaden ze wskazanych powyżej ustępów art. 9 dyrektywy IPPC nie odsyła w sposób wyraźny lub dorozumiany do tych poziomów emisji, przedstawiając szczegółowo przy każdym $\mathrm{z}$ tych przepisów swoje uzasadnienie $\mathrm{w}$ tym zakresie ${ }^{31}$.

Z kolei w odniesieniu do dyrektywy NEC Trybunał stwierdzil, że również żaden przepis tej dyrektywy nie ustanawia dla właściwych władz krajowych obowiazku uwzględnienia przy wydaniu pozwolenia środowiskowego krajowych poziomów emisji SO2 i NOx jako warunku pozwolenia. Wręcz przeciwnie - prawodawca unijny wyraźnie przewidział $w$ motywie 19 dyrektywy NEC, że ma ona być stosowana „bez uszczerbku dla prawodawstwa wspólnotowego dotyczącego emisji tych zanieczyszczeń z określonych źródet i przepisów dyrektywy [IPPC] $w$ odniesieniu do dopuszczalnych wielkości emisji i stosowania najlepszych dostępnych technik", dając $w$ ten sposób do zrozumienia, że obowiqzzi spoczywajq̨ce na państwach członkowskich na podstawie dyrektywy NEC nie mogq. wptywać bezpośrednio na obowiazki wynikajace między innymi z art. 9 dyrektywy IPPC. Wykładnię tę potwierdza $w$ końcu różny cel i systematyka obu dyrektyw ${ }^{32}$. W ocenie Trybunału celem dyrektywy IPPC, określonym $w$ jej art. 1, jest bowiem osiagnięcie zintegrowanego zapobiegania zanieczyszczeniom środowiska naturalnego i ich kontrola poprzez zastosowanie środków majacych na celu zapobieganie lub zmniejszenie emisji do powietrza, środowiska wodnego i gleby, aby osiagną́ wysoki poziom ochrony środowiska naturalnego. Takie zintegrowane podejście przejawia się $w$ odpowiedniej koordynacji warunków i procedury udzielania pozwoleń na funkcjonowanie instalacji przemysłowych o znacznym potencjale zanieczyszczeń (zob. podobnie w odniesieniu do dyrektywy 96/61 wyrok z dnia 22 stycznia 2009 r. w sprawie C-473/07 Association nationale pour la protection des eaux et rivières i OABA, $Z b$. Orz. TE I-319, pkt 25 i 26) ${ }^{33}$.

Następnie Trybunał dodał, że dyrektywa IPPC ustanawia $w$ tym celu zasady przyznawania pozwoleń i monitorowania du-

31 Sprawy C-165 do167/09, par. 56-69.

32 Sprawy C-165 do167/09, par. 69-71.

33 Sprawy C-165 do167/09, par. 72. 
$\dot{z} y c h$ instalacji przemystowych, oparte na podejściu zintegrowanym $i$ stosowaniu najlepszych dostępnych technik, to jest technik, które po uwzględnieniu kosztów i korzyści uznano za najskuteczniejsze, jeśli chodzi o zapewnienie wysokiego poziomu ochrony środowiska naturalnego. Dyrektywa NEC natomiast-jak wynika z jej art. 1 i 2 - zmierza do ograniczenia emisji z wszelkich źródet substancji zakwaszajacych i eutrofizujących oraz prekursorów ozonu w celu poprawy ochrony środowiska i ludzkiego zdrowia, tak aby $w$ dtugim okresie nie były przekraczane poziomy i ładunki krytyczne. Ponadto jak wynika wyraźnie z art. 4 oraz motywów 11 i 12 dyrektywy NEC, znajduje ona podstawe $w$ podejściu czysto programowym, zgodnie z którym państwa członkowskie posiadaja szeroki zakres swobody, jeżeli chodzi o wybór dziatań politycznych i środków, które należy przyjać lub zaplanować $w$ ramach krajowych programów dotyczqcych ogótu źródeł zanieczyszczeń $w$ celu stopniowego zredukowania w sposób strukturalny emisji w szczególności SO2 i NOx do ilości nieprzekraczających najpóźniej na koniec roku 2010 poziomów emisji wskazanych w załaczniku I do tej dyrektywy. Wynika z tego, że realizacja określonych $w$ niej celów nie może wptywać bezpośrednio na procedury wydania pozwolenia środowiskowego ${ }^{34}$.

Odpowiadając więc na pierwsze pytanie sądu krajowego Trybunał stwierdził, że art. 9 ust. 1, 3 i 4 dyrektywy IPPC nale$\dot{z} y$ interpretować $w$ ten sposób, $i \dot{z}$ wydajac pozwolenie środowiskowe na budowę i eksploatację instalacji przemystowej takiej jak te, których dotyczq sprawy przed sqdem krajowym, państwa członkowskie nie sq zobowiqzane do zaliczenia do warunków wydania tego pozwolenia krajowych poziomów emisji SO2 i NOx ustalonych $w$ dyrektywie NEC, przestrzegajac jednak wynikającego z dyrektywy NEC obowiqzku przyjęcia lub zaplanowania $w$ ramach programów krajowych działań politycznych oraz odpowiednich i spójnych środków, które ogółem umożliwiq redukcje emisji w szczególności tych zanieczyszczeń do ilości nieprzekraczajacych najpóźniej na koniec roku 2010 poziomów wskazanych w załączniku I do tej dyrektywy ${ }^{35}$.

34 Sprawy C-165 do167/09, par. 73-75.

35 Sprawy C-165 do167/09, par. 76. 
W odniesieniu do drugiego i trzeciego pytania sądu krajowego Trybunał przyjął, że pytania dotyczyły ustalenia z jednej strony, jakie zobowiązania spoczywają na państwach członkowskich na mocy dyrektywy NEC w okresie od 27 listopada 2002 r. - terminu jej transpozycji - do 31 grudnia 2010 r. - terminu, w którym państwa członkowskie powinny przestrzegać ustalonych w niej poziomów emisji. Z drugiej strony zaś, sąd krajowy zapytywał, czy ze względu na te zobowiązania właściwe władze krajowe mogą być zobowiązane do odmowy lub ograniczenia wydania pozwolenia środowiskowego albo przyjęcia szczególnych środków wyrównawczych w wypadku przekroczenia lub ryzyka przekroczenia krajowych poziomów emisji SO2 i NOx określonych w dyrektywie $\mathrm{NEC}^{36}$.

Oceniając obowiązki państwa członkowskiego co do powstrzymania się od przyjmowania przepisów, które mogłyby poważnie zagrozić realizacji celu wyznaczonego w dyrektywie, Trybunał po przywołaniu ogólnego orzecznictwa w tym aspekcie wskazał, że należy zatem przestrzegać również $w$ okresie przejściowym przewidzianym $w$ art. 4 dyrektywy NEC, $w$ trakcie którego państwa członkowskie sq uprawnione do tego, by jeszcze nie przestrzegać rocznych wielkości emisji krajowych wskazanych $w$ załaczniku I do tej dyrektywy. Do sqdu krajowego należy weryfikacja poszanowania tego zobowiqzania w świetle przepisów i środków, których legalność jest poddana jego analizie (zob. podobnie $w w$. wyrok $w$ sprawie Inter-Environnement Wallonie, par. 46). $W$ tym względzie należy jednak zaznaczyć, że weryfikacja taka musi być bezwzględnie prowadzona na podstawie oceny ogólnej z uwzględnieniem całości działań politycznych i środków przyjętych na danym terytorium krajowym ${ }^{37}$.

Następnie Trybunał dodał, że mając na uwadze system ustanowiony $w$ dyrektywie NEC, a w szczególności przyjęte w niej podejście programowe, [...]realizacje celu wyznaczonego $w$ tej dyrektywie państwa członkowskie moga poważnie podważać jedynie przez przyjęcie i wyprowadzenie w życie środków, które z uwagi w szczególności na ich konkretne skutki jak i czas trwania toleruja lub 
stwarzaja krytycznq sytuacje, jeśli chodzi o całkowita ilość emisji do atmosfery ze wszystkich źródet zanieczyszczeń, które ze swej natury automatycznie zagrażaja przestrzeganiu na koniec roku 2010 poziomów wskazanych w załaczniku I do tej dyrektywy (zob. podobnie $w w$. wyrok Inter-Environnement Wallonie, par. 47 i 49). Wynika z tego, że zwykły środek szczególny dotyczqcy jednego źródła SO2 i NOx, który stanowitaby decyzja $w$ sprawie wydania pozwolenia środowiskowego na budowę i eksploatację instalacji przemysłowej, nie może sam poważnie zagrozić celowi wyznaczonemu $w$ dyrektywie NEC, a mianowicie ograniczeniu emisji tych zanieczyszczeń do atmosfery do rocznych ilości całkowitych nieprzekraczajacych wspomnianych poziomów krajowych najpóźniej w 2010 r. Wniosek ten jest tym bardziej zasadny, jeżeli $w$ okolicznościach takich jak $w$ postępowaniu przed sq̨dem krajowym dana instalacja ma być uruchomiona najwcześniej w roku $2012^{38}$.

Ostatecznie Trybunał uznał, że na pytania drugie i trzecie należy odpowiedzieć $\mathrm{w}$ ten sposób, że w okresie przejściowym od 27 listopada 2002 r. do 31 grudnia 2010 r., przewidzianym w art. 4 dyrektywy NEC:

- art. 4 ust. 3 TUE i art. 288 akapit trzeci TFUE oraz dyrektywa NEC wymagaja, by państwa członkowskie powstrzymały się od przyjmowania przepisów, które moga poważnie zagrażać osiagnięciu celu wyznaczonego $w$ tej dyrektywie;

- samo przyjęcie przez państwa członkowskie szczególnego środka dotyczqcego jednego źródta SO2 i NOx nie może poważnie zagrozić celowi wyznaczonemu $w$ dyrektywie NEC. Do sqdu krajowego należy zweryfikowanie, czy ma to miejsce $w$ wypadku każdej z decyzji o wydaniu pozwolenia środowiskowego na budowe i eksploatacje instalacji przemystowej, takiej jak te, których dotyczq sprawy przed sadem krajowym;

- art. 288 akapit trzeci TFUE oraz art. 6, art. 7 ust. 1 i 2 i art. 8 ust. 1 i 2 dyrektywy NEC nakładajq na państwa członkowskie z jednej strony wymóg opracowania, aktualizacji $i w$ razie potrzeby rewizji krajowych programów stopniowej redukcji emisji SO2 i NOx, które zobowiqzane sq podać do wiadomo-

38 Sprawy C-165 do167/09, par. 82-83. 
Ści publicznej i odpowiednich organizacji w jasny, zrozumiaty i łatwo dostępny sposób, jak tė̇ przekazać Komisji w wyznaczonych terminach, a z drugiej strony wymóg sporzqdzenia i corocznego aktualizowania krajowych inwentaryzacji emisji wspomnianych zanieczyszczeń oraz prognoz krajowych na 2010 r., które $w$ wyznaczonych terminach należy przekazywać Komisji i Europejskiej Agencji Ochrony Środowiska;

- art. 288 akapit trzeci TFUE i sama dyrektywa NEC nie wymagajq od państw członkowskich ani odmowy badź ograniczenia wydania pozwolenia środowiskowego, takiego jak pozwolenia będace przedmiotem spraw przed sqdem krajowym, ani przyjęcia szczególnych środków wyrównawczych dla każdego wydanego pozwolenia tego rodzaju, nawet $w$ wypadku przekroczenia lub ryzyka przekroczenia krajowych poziomów emisji SO2 i NOx ${ }^{39}$.

W przedmiocie pytań od czwartego do szóstego, które w ocenie Trybunału należało zbadać wspólnie, sąd krajowy zwracał się o ustalenie, czy i ewentualnie w jakim zakresie jednostka może powołać się bezpośrednio przed sądami krajowymi na zobowiązania nałożone w art. 4 i 6 dyrektywy NEC. Odpowiadając na te pytania, po przypomnieniu ogólnego orzecznictwa dotyczącego zasady skutku bezpośredniego przepisów prawa unijnego, Trybunał stwierdził, że art. 4 dyrektywy NEC nie spełnia warunków testu skutku bezpośredniego ${ }^{40}$. W ocenie Trybunału artykut ten - rozpatrywany $w$ swoim kontekście - ma bowiem charakter czysto programowy, gdyż ogranicza się do wskazania zamierzonego celu, pozostawiając państwom członkowskim szeroki zakres swobody $w$ odniesieniu do środków, które należy zastosować, aby ten cel osiagnać. Wynika z tego, że ponieważ art. 4 dyrektywy NEC nie przewiduje żadnego bezwarunkowego $i$ wystarczajaco precyzyjnego obowiązku podjęcia działań politycznych lub szczególnych środków jednostkowych mających umożliwić realizacje wyznaczonego celu, jednostki nie moga powotywać się na ten artykuł bezpośrednio przed sqdami krajowymi, podnoszqc przed dniem 31 grudnia 2010 r. żadanie, by wtaściwe władze odmówity lub ograniczyły wy-

40 Sprawy C-165 do167/09, par. 92, 96. 
danie decyzji o przyznaniu pozwolenia środowiskowego, takiej jak te, których dotyczq sprawy przed sqdem krajowym, lub by przyjęty szczególne środki wyrównawcze po wydaniu takiego pozwolenia ${ }^{41}$.

Natomiast w przypadku art. 6 dyrektywy NEC, Trybunał stwierdzil, że przepis ten taki test spełnia, gdy $\dot{z} w$ jednoznaczny sposób nakłada na państwa członkowskie z jednej strony, zgodnie z jego ust. 1-3, wymóg opracowania programów stopniowej redukcji krajowych emisji w szczególności SO2 i NOx $w$ celu zastosowania się do poziomów wskazanych $w$ załq̨cziku I do tej dyrektywy najpóźniej do końca roku 2010, a z drugiej strony, zgodnie z jego ust. 4, wymóg podania tych programów do wiadomości publicznej $i$ odpowiednich organizacji $w$ jasny, zrozumiaty $i$ tatwo dostępny sposób. Wynika z tego, że osoby fizyczne i prawne, których pozwolenie dotyczy bezpośrednio, powinny mieć możliwość spowodowania, ewentualnie zwracając się do sq̨dów krajowych, by właściwe władze przestrzegaty i wykonaty takie normy prawa Unii ${ }^{42}$.

Kontynuując swoje rozważania $\mathrm{w}$ tym przedmiocie Trybunał dodał, że jeżeli chodzi o treść programów, które maja być opracowane, [...] państwa członkowskie posiadajq szeroki zakres swobody przy wyborze szczególnych inicjatyw, które należy wdro$\dot{z} y c ́$, nie maja one też obowiqzku podjęcia takich działań politycznych i środków, by do żadnego przekroczenia nie doszło przed końcem 2010 r. Niemniej z art. 6 dyrektywy NEC jak i systematyki tej dyrektywy, która zmierza do stopniowej redukcji krajowych emisji wyraźnie wskazanych zanieczyszczeń, wynika, że w okresie przejściowym od 27 listopada 2002 r. do 31 grudnia 2010 r. państwa członkowskie sq zobowiazane do przyjęcia lub zaplanowania działań politycznych oraz odpowiednich i spójnych środków, które ogótem umożliwiq redukcję emisji tych zanieczyszczeń, tak aby dostosować się do krajowych poziomów przewidzianych $w$ załązniku I do tej dyrektywy. Z tej perspektywy należy wskazać, że o ile państwom członkowskim przystuguje tym samym zakres uznania, to jednak art. 6 dyrektywy NEC określa granice jego wykonania, na które można powotywać się przed sq̨dami krajowymi, jeżeli chodzi o adekwatność ogótu działań politycznych i środków przyjętych lub

41 Sprawy C-165 do167/09, par. 97-98.

42 Sprawy C-165 do167/09, par. 99-100. 
zaplanowanych $w$ ramach odpowiednich programów krajowych względem celu redukcji najpóźniej do końca roku 2010 emisji wskazanych zanieczyszczeń do ilości nieprzekraczających poziomów ustalonych dla każdego państwa członkowskiego (zob. podobnie ww. wyrok $w$ sprawie Janecek, par. 46) ${ }^{43}$.

\section{SUBSTANCJE NIEBEZPIECZNE}

\section{WYROK TRYBUNAŁU Z DNIA 19 MAJA 2011 R. \\ W SPRAWIE C-376/09 KOMISJA EUROPEJSKA \\ PRZECIWKO REPUBLICE MALTY ${ }^{44}$}

1) Skarga zostaje oddalona.

2) Komisja Europejska zostaje obciążona kosztami postępowania.

W skardze Komisja Wspólnot Europejskich domagała się, by Trybunał stwierdził, że nie wycofując z eksploatacji systemów przeciwpożarowych i gaśnic zawierających halony, przeznaczonych do zastosowań niekrytycznych na pokładach statków, ani nie odzyskując takich halonów, Republika Malty uchybiła zobowiązaniom ciążącym na niej na mocy art. 4 ust. 4 ppkt v) oraz art. 16 rozporządzenia (WE) nr 2037/2000 Parlamentu Europejskiego i Rady z dnia 29 czerwca 2000 r. w sprawie substancji zubożających warstwę ozonową ${ }^{45}$ zmienionego decyzją 2004/232/WE Komisji z dnia 3 marca 2004 r.

Przystępując do analizy zarzutów przedłożonych przez Komisję w skardze, Trybunał wskazał, że zgodnie z art. 4 ust. 1 ppkt c) rozporządzenia nr 2037/2000 zakazane zostało wprowadza-

43 Sprawy C-165 do167/09, par. 101-103.

44 http://curia.eu, dalej cyt.: sprawa C-376/09.

45 Dz. Urz. UE L 244 z 29.9.2000, s. 1-24, uchylone z dniem 31 grudnia 2009 r. w drodze rozporządzenia PE i Rady (WE) nr 1005/2009 z dnia 16 września 2009 r. w sprawie substancji zubożających warstwę ozonową, Dz. Urz. UE L 286 z 31.10.2009, s. 1-30. 
nie do obrotu i stosowania halonów z zastrzeżeniem art. 4 ust. 4 i 5 tego aktu. Artykuł 4 ust. 4 ppkt v) przewidywał obowiązek wycofania z użycia systemów przeciwpożarowych i gaśnic zawierających halony przed dniem 31 grudnia 2003 r. z wyjątkiem zastosowań wymienionych w załączniku VII do rozporządzenia nr 2037/2000. Wobec braku odmiennych przepisów w akcie przystąpienia, obowiązek ten wszedł w życie wobec Republiki Malty od chwili jej przystąpienia do Unii Europejskiej, w dniu 1 maja 2004 r., na podstawie art. 2 owego aktu. W ocenie Trybunału z wykładni całości powyższych przepisów wynikało, że począwszy od wskazanej daty, zastosowanie tego rodzaju systemów i gaśnic było w przypadku statków pływających pod banderą maltańską dopuszczalne jedynie wówczas, gdy mogło ono zostać uznane za „zastosowanie krytyczne” w rozumieniu wskazanego załącznika ${ }^{46}$.

W sprawie C-376/09 Republika Malty nie kwestionowała okoliczności, że niektóre statki pływające pod banderą maltańską były wyposażone w systemy gaśnicze stosujące halon. Jednakże wskazywała, że zastosowanie to jest objęte wskazanym pojęciem „zastosowanie krytyczne” kwestionując dokonaną przez Komisję, restrykcyjną wykładnię owego pojęcia. W tym względzie Trybunał przypomniał, że zgodnie z utrwalonym orzecznictwem w ramach postępowania w sprawie stwierdzenia uchybienia zobowiązaniom państwa członkowskiego Komisja zobowiązana jest do wykazania istnienia zarzucanego uchybienia i dostarczenia Trybunałowi dowodów potrzebnych do sprawdzenia przezeń istnienia tego uchybienia, przy czym Komisja nie może opierać się na jakimkolwiek domniemaniu (zob. w szczególności wyroki: z dnia 12 maja 2005 r. w sprawie C-287/03 Komisja przeciwko Belgii, Zb.Orz. TE I-3761, par. 27; z dnia 10 czerwca 2010 r. w sprawie C-37/09 Komisja przeciwko Portugalii, par. 28$)^{47}$.

W tym zakresie Trybunał stwierdził, że przedstawiona przez Komisję wykładnia tirets trzecich dotyczących zastosowania krytycznego, odpowiednio, halonu 1301 i halonu 2402, zawartych

46 Sprawa C-376/09, par. 28-30.

47 Sprawa C-376/09, par. 31-32. 
w załączniku VII do rozporządzenia nr 2037/2000 została oparta na dwóch argumentach. Po pierwsze, systemy stosujące halon, zainstalowane na większości statków są systemami gaszenia, a nie systemami tworzenia przestrzeni ochronnej. Po drugie jedynie dwa szczególne przypadki zastosowania systemów zawierających halony dla celów tworzenia przestrzeni ochronnej są objęte tymi przepisami, a mianowicie na tankowcach lub wokół maszyn służących do automatycznego przepompowywania mąki $\mathrm{w}$ ładowni statku lub poza nią. Jednakże zdaniem Trybunału, wykładnia ta nie wynikała ani z przepisów wskazanego załącznika, ani z pozostałych przepisów rozporządzenia nr 2037/2000. Ponadto, jakiekolwiek odesłanie do owych dwóch przypadków wskazanych przez Komisję nie było zawarte w motywach tego rozporządzenia. Jednocześnie trzy tirets dotyczące zastosowania, odpowiednio, halonów 1301 i 2402, zawarte w załączniku VII do rozporządzenia nr 2037/2000 zostały ujęte przy użyciu sformułowań o szerokim zakresie, odnoszących się do ich zastosowania „W siłach zbrojnych oraz w sektorze nafty, gazu i petrochemicznym, jak również w istniejących statkach towarowych". Ponadto, sformułowanie „tworzenie przestrzeni ochronnej na zajętych powierzchniach" zawarte we wskazanych przepisach wskazuje, że omawiane zastosowanie halonów zostało przewidziane na powierzchniach zajętych przez ludzi, co mogło obejmować inne rodzaje lub części statków, niż te wskazane przez Komisję ${ }^{48}$.

W związku z powyższym Trybunał uznał, że nawet gdyby przyjąć, jak podnosiła Komisja, iż w praktyce użycie halonu na statkach jest ograniczone do dwóch wskazanych przez nią przypadków, to jednak brak było w tekście rozporządzenia nr 2037/2000 jakichkolwiek wskazań pozwalających przyjąć, że intencją prawodawcy Unii było ograniczenie zastosowania halonu na statkach do tych dwóch przypadków. Z tego względu Trybunał stwierdził, że Komisja nie zdołała wykazać istnienia zarzucanego Republice Malty uchybienia i skargę oddalił ${ }^{49}$. 


\section{OCHRONA KLIMATU}

\section{VI.1. WYROK SĄDU Z DNIA 22 MARCA 2011 R. W SPRAWIE T-369/07 REPUBLIKA ŁOTEWSKA PRZECIWKO KOMISJI EUROPEJSKIEJ ${ }^{50}$}

1) Stwierdza się nieważność decyzji Komisji C(2007) 3409 z dnia 13 lipca 2007 r. dotyczącej krajowego planu rozdziału uprawnień do emisji gazów cieplarnianych notyfikowanego przez Republikę Łotewską na lata 2008-2012 zgodnie z dyrektywą 2003/87/WE Parlamentu Europejskiego i Rady z dnia 13 października 2003 r. ustanawiającą system handlu przydziałami emisji gazów cieplarnianych we Wspólnocie oraz zmieniającą dyrektywę Rady 96/61/WE.

2) Komisja Europejska pokrywa własne koszty oraz koszty poniesione przez Republikę Łotewską.

3) Republika Litewska, Republika Słowacka oraz Zjednoczone Królestwo Wielkiej Brytanii i Irlandii Północnej ponoszą koszty własne.

W sprawie T-369/07 okoliczności faktyczne przedstawiały się w sposób następujący. Pismem z dnia 16 sierpnia 2006 r. Republika Łotewska notyfikowała Komisji, zgodnie z art. 9 ust. 1 dyrektywy 2003/87, krajowy plan rozdziału uprawnień (KPRU) do emisji gazów cieplarnianych w latach 2008-2012. Zgodnie z KPRU Republika Łotewska przyznała na rzecz przemysłu krajowego objętego zakresem zastosowania załącznika I do dyrektywy 2003/87, średnią roczną wynoszącą ogółem 7,763883 mln ton ekwiwalentu CO2 (MteCO2). Następnie pismem z dnia 29 grudnia 2006 r. Republika Łotewska notyfikowała KPRU będący wynikiem rewizji, przewidujący rozdział całkowitej średniej ilości przydziałów w wysokości 6,253146 MteCO2 rocznie. Z kolei Komisja w piśmie z dnia 30 marca 2007 r., zredagowanym $w$ języku angielskim stwierdziła, że informacje zawarte

50 http://curia.eu; dalej cyt.: sprawa T-369/07. 
w KPRU, będącym wynikiem rewizji były niepełne i zwróciła się do Republiki Łotewskiej o udzielenie odpowiedzi na pewne pytania i dostarczenie jej informacji uzupełniających. Pismem z dnia 25 kwietnia 2007 r. Republika Łotewska ustosunkowała się do żądania informacji. W następstwie wymiany tych dokumentów Komisja w dniu 13 lipca 2007 r. wydała zaskarżoną decyzję dotyczącą krajowego planu rozdziału uprawnień do emisji gazów cieplarnianych notyfikowanego przez Łotwę na lata 2008-2012 $2^{51}$.

W swojej skardze o stwierdzenie nieważności tej decyzji Republika Łotewska przedstawiła cztery zarzuty dotyczące: po pierwsze - naruszenia uprawnień ustanowionych traktatem WE w dziedzinie polityki energetycznej, po drugie - naruszenia „zasady niedyskryminacji”, po trzecie - brak spełnienia zobowiązań wynikających z protokołu z Kioto i po czwarte - nieprzestrzeganie terminu trzech miesięcy przewidzianego w art. 9 ust. 3 dyrektywy 2003/87. W ocenie Republiki Łotewskiej zaskarżona decyzja powinna być zakwalifikowana jako „nieistniejąca”, ponieważ została ona wydana z naruszeniem art. 9 ust. 3 dyrektywy 2003/87. Zgodnie z tym przepisem w ciągu trzech miesięcy od notyfikacji KPRU przez państwo członkowskie Komisja może odrzucić ten plan. KPRU będący wynikiem rewizji został notyfikowany w dniu 29 grudnia 2006 r. Termin, w którym Komisja była zobowiązana zareagować, jeżeli ma zamiar odrzucić KPRU w całości lub w części, upłynął w dniu 29 marca 2007 r. Jednakże dopiero w dniu 30 marca 2007 r. Komisja skierowała pismo do Republiki Łotewskiej - zredagowany poza tym w języku angielskim, z naruszeniem art. 3 rozporządzenia Rady nr 1 z dnia 15 kwietnia 1958 r. w sprawie określenia systemu językowego Europejskiej Wspólnoty Ekonomicznej - w którym z jednej strony wskazywała, że KPRU będący wynikiem rewizji był niekompletny, a z drugiej strony domagała się dodatkowych wyjaśnień. Wreszcie Republika Łotewska uściśla, że termin trzech miesięcy przewidziany w art. 9 ust. 3 dyrektywy 2003/87 rozpoczął bieg od dnia, w którym jej pismo z dnia 29 grudnia 2006 r. dotyczące notyfikacji KPRU, będącego wynikiem rewizji zostało rzeczywi- 
ście doręczone Komisji, a nie w następstwie potwierdzenia jego odbioru w dniu 5 stycznia $2007 \mathrm{r}^{52}$

Analizując zagadnienie prawa Komisji do przeprowadzenia kontroli na podstawie art. 9 ust. 3 dyrektywy 2003/87, Sąd wskazał, że zgodnie z art. 9 ust. 3 zdanie pierwsze dyrektywy 2003/87 w ciągu trzech miesięcy od notyfikacji KPRU przez państwo członkowskie Komisja może odrzucić ten plan lub jakikolwiek jego aspekt na tej podstawie, iż jest on niezgodny z kryteriami wymienionymi w załączniku III lub przepisami art. 10 tej dyrektywy. Zgodnie z brzmieniem zdania drugiego tego przepisu - państwo członkowskie podejmuje decyzję wyłącznie na podstawie art. 11 ust. 1 lub 2 tej dyrektywy, jeśli proponowane zmiany są przyjęte przez Komisję. Wreszcie zdanie trzecie tego przepisu przewiduje, że Komisja uzasadnia każdą decyzję o odrzuceniu. Jak zostało potwierdzone orzecznictwem, przysługujące Komisji na podstawie art. 9 ust. 3 dyrektywy 2003/87 prawo do przeprowadzenia kontroli i odrzucenia KPRU ma bardzo ograniczony zakres - tak z punktu widzenia przedmiotowego, jak i czasowego. Z jednej strony kontrola ta ogranicza się bowiem do badania przez Komisję zgodności KPRU z kryteriami określonymi w załączniku III i z przepisami art. 10 dyrektywy 2003/87, a z drugiej strony powinna zostać przeprowadzona w terminie trzech miesięcy od notyfikacji KPRU przez państwo członkowskie (postanowienie Sądu z dnia 30 kwietnia 2007 r. w sprawie T-387/04 EnBW Energie Baden-Württemberg przeciwko Komisji, Zb. Orz. TE II-1195, par. 104; zob. podobnie wyrok Sądu z dnia 7 listopada 2007 r. w sprawie T-374/04 Niemcy przeciwko Komisji, Zb. Orz. TE II-4431, par. 116) ${ }^{53}$.

Ponadto Sąd dodał, iż wcześniej dokonana na podstawie art. 9 ust. 3 dyrektywy 2003/87 kontrola niekoniecznie prowadzi do wydania decyzji przez Komisję. W następstwie notyfikowania KPRU Komisja ma z pewnością obowiązek wnikliwej i bezstronnej oceny jego zgodności z kryteriami załącznika III i z przepisami art. 10 dyrektywy 2003/87. Z wyrażenia „może odrzucić” wynika jednak, że Komisja dysponuje pewną swobodą

52 Sprawa T-369/07, par. 30, 38.

53 Sprawa T-369/07, par. 45-46. 
uznania w tym zakresie. Wynika stąd ponadto, że jeżeli Komisja zrzeka się w okresie trzech miesięcy następujących po notyfikacji KPRU przez państwo członkowskie wykonywania tego prawa, państwo członkowskie może co do zasady wykonać wspomniany KPRU zgodnie z przesłankami określonymi w art. 11 i nast. dyrektywy 2003/87, bez konieczności uzyskania zgody Komisji. W ten sposób procedura oceny KPRU nie musi zakończyć się wydaniem formalnej decyzji, w szczególności w sytuacji, w której państwo członkowskie wprowadza w trakcie tej procedury wszelkie wymagane zmiany. Komisja może natomiast uczynić użytek ze swych uprawnień decyzyjnych, zgodnie z art. 9 ust. 3 zdanie drugie dyrektywy 2003/87 w sytuacji, w której państwo członkowskie wstrzymuje się lub odmawia wprowadzenia zmian w swym KPRU przed upływem terminu trzech miesięcy, mimo podniesionych zastrzeżeń. W przypadku braku tego rodzaju decyzji Komisji o odrzuceniu KPRU, KPRU notyfikowany staje się wiążący i korzysta $\mathrm{z}$ domniemania legalności, upoważniając państwo członkowskie do jego wykonania (zob. podobnie ww. w pkt 46 postanowienie w sprawie EnBW Energie Baden-Württemberg przeciwko Komisji, par. 106, 107, 111, 115, 120) ${ }^{54}$.

Zdaniem Sądu Komisja nie może skutecznie podnosić, że art. 9 ust. 3 zdanie drugie dyrektywy 2003/87, który wspomina o „zaproponowanych zmianach”, jakie winny być „przyjęte przez Komisję", wymaga formalnego wydania decyzji dotyczącej przyjęcia zmian. Tak jak wcześniej orzekał Sąd, wspomniane zmiany mają miejsce $\mathrm{w}$ trakcie następnego etapu badania KPRU, mianowicie w następstwie zgłoszenia przez Komisję zastrzeżeń w odniesieniu do notyfikowanego KPRU lub niektórych jego aspektów, przy czym celem tych zmian jest właśnie usunięcie przyczyn zastrzeżeń formułowanych początkowo przez Komisję w zakresie ich zgodności z kryteriami załącznika III i przepisami art. 10 dyrektywy 2003/87. Stąd też przyjęcie wspomnianych zmian przez Komisję jest wyłącznie konsekwencją zastrzeżeń początkowo formułowanych przez Komisję w ramach jej prawa do kontroli i ograniczonego prawa do odrzucenia KPRU, na pod- 
stawie art. 9 ust. 3 dyrektywy 2003/87, a nie wyrazem ogólnego prawa Komisji przyjmowania KPRU (ww. w pkt 46 postanowienie $\mathrm{w}$ sprawie EnBW Energie Baden-Württemberg przeciwko Komisji, pkt 104). Poza tym z przytoczonego orzecznictwa nie wynika, że przyjęcie przez Komisję zmian wprowadzonych do KPRU winno być przedmiotem formalnej decyzji Komisji. Przeciwnie, po pierwsze, tego rodzaju wykładnia sprzeciwiałaby się zasadzie, zgodnie z którą Komisja nie dysponuje ogólnym prawem przyjmowania KPRU. Po drugie, nie zgadzałaby się z systematyką art. 9 ust. 3 zdanie trzecie dyrektywy 2003/87, który dotyczy wyłącznie decyzji o odrzuceniu i decyzji o przyjęciu KPRU. W świetle tych zasad należało oceniać, zdaniem Sądu, czy w sprawie T-369/07 Komisja przestrzegała przepisów art. 9 ust. 3 dyrektywy $2003 / 87^{55}$.

Zajmując się zagadnieniem pojęcia notyfikacji w rozumieniu art. 9 ust. 3 dyrektywy 2003/87, Sąd uznał, że należy stwierdzić, iż pojęcie notyfikacji w rozumieniu art. 9 ust. 3 dyrektywy 2003/87 dotyczy zarówno pierwszej notyfikacji, jak i następnych dotyczących różnych wersji KPRU, z tym skutkiem, że każda z tych notyfikacji rozpoczyna bieg nowego terminu trzech miesięcy. Z kolei w przedmiocie upływu terminu trzech miesięcy przewidzianego w art. 9 ust. 3 dyrektywy 2003/87, Sąd stwierdził, że brak proceduralny polegający na naruszeniu terminu trzech miesięcy, w rozumieniu art. 9 ust. 3 dyrektywy 2003/87, nie jest tak poważny i oczywisty, by uzasadniać uznanie zaskarżonej decyzji za nieistniejącą (zob. wyrok Trybunału z dnia 6 marca 2008 r. w sprawie C-196/07 Komisja przeciwko Hiszpanii, par. 35 i przytoczone tam orzecznictwo). Akty instytucji, nawet te wadliwe, korzystają z domniemania ważności i wywołują skutki prawne do czasu ich cofnięcia lub stwierdzenia nieważności w wyniku skargi o stwierdzenie nieważności, pytania prejudycjalnego lub zarzutu niezgodności z prawem (wyrok Sądu z dnia 23 października 2008 r. w sprawie T-256/07 People's Mojahedin Organization of Iran przeciwko Radzie, Zb. Orz. TE II-3019, pkt 55 i przytoczone tam orzecznictwo). Jak to zostało wskazane wyżej,

55 Sprawa T-369/07, par. 48-49. 
mając na względzie cechy szczególne badania KPRU wynikające z art. 9 ust. 3 dyrektywy 2003/87, zgodnie z zasadami tego badania w przypadku braku wydania decyzji przez Komisję w terminie trzech miesięcy KPRU staje się wiążący i korzysta $\mathrm{z}$ domniemania legalności. Niemniej jednak niezgodność z prawem stwierdzona w niniejszej sprawie, mianowicie fakt, iż zaskarżona decyzja została wydana po terminie, nie może zostać uznana za do tego stopnia poważną i oczywistą, by powodowała nieistnienie decyzji. Mając bowiem na względzie podstawową zasadę pewności prawa, stwierdzenie nieistnienia aktu winno zostać zarezerwowane dla prawdziwie wyjątkowych przypadków (zob. podobnie wyroki Trybunału: z dnia 15 czerwca 1994 r. w sprawie C-137/92 P Komisja przeciwko BASF $i$ in., Zb. Orz. TE I-2555, par. 48, 50; z dnia 8 lipca 1999 r. w sprawie C-245/92 P Chemie Linz przeciwko Komisji, Zb. Orz. TE I-4643, par. 93, 95; z dnia 5 października 2004 r. w sprawie C-475/01 Komisja przeciwko Grecji, Zb. Orz. TEI-8923, par. 18, 20). W związku z powyższym Sąd uznał, że należy stwierdzić nieważność zaskarżonej decyzji ze względu na naruszenia art. 9 ust. 3 dyrektywy 2003/87 bez potrzeby orzekania w przedmiocie dopuszczalności zasadności innych zarzutów podniesionych przez Republikę Łotewską ${ }^{56}$. 


\section{VI.2. SPRAWA C-267/11 P - ODWOŁANIE OD WYROKU SĄDU}

WYDANEGO W DNIU 22 MARCA 2011 R.

W SPRAWIE T-369/07 REPUBLIKA ŁOTEWSKA

PRZECIWKO KOMISJI EUROPEJSKIEJ,

\section{WNIESIONE W DNIU 30 MAJA 2011 R. PRZEZ KOMISJĘ EUROPEJSKA ${ }^{57}$}

Żądania wnoszącego odwołanie:

- uchylenie wyroku będacego przedmiotem niniejszego odwołania;

- obciqżenie Republiki Łotewskiej kosztami postępowania.

Zarzuty i główne argumenty:

Jedyny zarzut odwołania dotyczy niedochowania terminu trzech miesięcy ustanowionego w art. 9 ust. 3 dyrektywy 2003/87/ $W E^{58}$. Komisja uważa, $\dot{z} e w$ swej analizie Sąd połaczył zdania pierwsze $i$ drugie art. 9 ust. $3 i w$ konsekwencji ta wykładnia nie jest zgodna z celami ustanowionymi we wspomnianym ustępie. Ta wykładnia art. 9 ust. 3 dyrektywy jest sprzeczna z wykładnia dokonana przez sam Są $w$ innej sprawie, $w$ której stusznie stwierdzit, że art. 9 ust. 3 zdanie drugie stanowi odrębnq podstawę prawna. $W$ swej wykładni art. 9 ust. 3 tej dyrektywy Komisja opiera się na dostownym brzmieniu przepisu, który $w$ petni odpowiada również celowi wspomnianego przepisu. $W$ rezultacie, $w$ przypadku gdy Komisja odrzuci krajowy plan rozdzielenia zgłoszony przez państwo członkowskie, państwo członkowskie powinno zmienić ten plan uwzględniając zastrzeżenia podniesione przez Komisję i nie będzie mogło wykonać planu, dopóki Komisja nie przyjmie zmian. Nie ustanowiono terminu na wydanie tej pozytywnej decyzji o wydaniu zgody. Komisja zaznacza, 亡̇e sporna decyzja była decyzja. $w$ sprawie zmian do krajowego planu rozdzielenia a nie dotyczqca. samego zgłoszonego krajowego planu rozdzielenia. Jednakize, ponieważ Sad nie orzekt, że art. 9 ust. 3 zdanie drugie tej dyrektywy

57 Dz. Urz. UE C 226 z 30.07.2011, s. 17.

58 Dyrektywa 2003/87/WE Parlamentu Europejskiego I Rady z dnia 13 października 2003 r. ustanawiająca system handlu przydziałami emisji gazów cieplarnianych we Wspólnocie oraz zmieniająca dyrektywę Rady 96/61/ WE, Dz. Urz. UE L 275 z 25.10.2003, s. 32-46 ze zm. 
ustanawia odrębne postępowanie, był on zobowiazany do uznania zgloszonych zmian za notyfikację nowego krajowego planu rozdzielenia i $w$ rezultacie do niewtaściwego zastosowania terminu trzech miesięcy.

\section{OCENA ODDZIAŁYWANIA NA ŚRODOWISKO}

\section{VII.1. WYROK TRYBUNAŁU Z DNIA 3 MARCA 2011 R. W SPRAWIE C-50/09 KOMISJA EUROPEJSKA PRZECIWKO IRLANDII ${ }^{59}$}

1) Irlandia:

- nie dokonując transpozycji art. 3 dyrektywy Rady 85/337/EWG z dnia 27 czerwca 1985 r. w sprawie oceny skutków wywieranych przez niektóre przedsięwzięcia publiczne i prywatne na środowisko naturalne ${ }^{60}$, zmienionej dyrektywą Rady 97/11/WE z dnia 3 marca 1997 r. $^{61}$ i dyrektywą 2003/35/WE Parlamentu Europejskiego i Rady z dnia 26 maja 2003 r. ${ }^{62}$,

- poprzez brak zagwarantowania, aby nastąpiło całkowite spełnienie wymogów ustanowionych $\mathrm{w}$ art. 2-4 dyrektywy 85/337, zmienionej dyrektywą 2003/35 w zakresie, w jakim irlandzkie organy do spraw zagospodarowania przestrzennego i agencja ochrony środowiska posiadają kompetencje decyzyjne w zakresie przedsięwzięć oraz

59 http://curia.eu; dalej cyt.: sprawa C-50/09.

60 Dz. Urz. UE L 175 z 5.7.1985, s. 40-48 ze zm.

61 Dz. Urz. UE L 73 z 14.3.1997, s. 5-15.

62 Dyrektywa 2003/35/WE Parlamentu Europejskiego i Rady z dnia 26 maja 2003 r. przewidująca udział społeczeństwa w odniesieniu do sporządzania niektórych planów i programów w zakresie środowiska oraz zmieniająca w odniesieniu do udziału społeczeństwa i dostępu do wymiaru sprawiedliwości dyrektywy Rady 85/337/EWG i 96/61/WE, Dz. Urz. UE L 156 z 25.6.2003, i/2011 s. $17-25$.

PRLEEGLĄD PRAWA OCHRONY ŚRODOWISKA 


\section{- w wyniku wyłączenia robót rozbiórkowych z zakresu przepisów transponujących dyrektywę 85/337, zmie- nioną dyrektywą 2003/35, uchybiła zobowiązaniom państwa członkowskiego ciążącym na niej na mocy tej dyrektywy.}

2) Irlandia zostaje obciążona kosztami postępowania.

W sprawie C-50/09 Komisja wystąpiła Trybunału ze skargą przeciwko Irlandii, uznając, że dyrektywa 85/337 nie została przez to państwo członkowskie w pełni i prawidłowo wdrożona. W szczególności Komisja zarzuciła Irlandii następujące trzy naruszenia: brak transpozycji art. 3 dyrektywy 85/337, brak zagwarantowania całkowitego spełnienia wymogów ustanowionych w art. 2-4 tej dyrektywy w zakresie, w jakim kompetencje decyzyjne w zakresie przedsięwzięcia przyznane zostały zarówno irlandzkim organom do spraw zagospodarowania przestrzennego, jak i Environmental Protection Agency (agencji ochrony środowiska), i po trzecie - wyłączenie robót rozbiórkowych z zakresu przepisów transponujących dyrektywę 85/337.

Analizując pierwszy zarzut ze skargi Komisji Trybunał zaznaczył, że zarówno Komisja i Irlandia odmiennie interpretowały art. 3 dyrektywy 85/337 i $w$ różny sposób oceniały jego zwiqzek z art. 4-11 tej dyrektywy. Komisja podkreślała, że art. 3 ustanawia zobowiqzzania, które wykraczają poza zobowiq̨ania wymagane $w w w$. art. 4-11, podczas gdy Irlandia wskazywata, że jest on przepisem sformutowanym $w$ sposób ogólny $i$ że szczegótowy opis procesu oceny oddziatywania na środowisko zostat wyjaśniony $w$ art. 4-11. Zdaniem Trybunatu, o ile art. 3 rzeczonej dyrektywy stanowi, iż ocena oddziatywania na środowisko odbywa się „zgodnie z art. 4-11" tej dyrektywy, o tyle zobowiqzania określone w tych artykułach sq odmienne od zobowiqzania ustanowionego $w$ samym art. $3^{63}$.

Następnie Trybunał stwierdził, że art. 3 dyrektywy 85/337 nakłada na właściwy organ do spraw środowiska zobowiqzanie do dokonania oceny oddziatywania na środowisko, która powinna obejmować opis ocenienia bezpośrednich i pośrednich skutków

\footnotetext{
63 Sprawa C-50/09, par. 34-35.
} 
przedsięwzięcia dla elementów wymienionych $w$ trzech pierwszych tiret tego artykułu i wzajemnych oddziaływań między nimi (wyrok z dnia 16 marca 2006 r. w sprawie C-332/04 Komisja przeciwko Hiszpanii, par. 33). Jak wskazuje art. 2 ust. 1 tej samej dyrektywy, oceny tej należy dokonać przed udzieleniem zezwolenia, którego wydania zażądano $w$ celu realizacji przedsięwzięcia. $W$ celu spetnienia zobowiazania ciażacego na niej zgodnie z omawianym art. 3 właściwy organ środowiskowy nie może ograniczyć się do określenia i opisania bezpośrednich i pośrednich skutków przedsięwzięcia dla niektórych elementów, lecz musi również ocenić je w odpowiedni sposób dla każdego indywidualnego przypadku. To zobowiazanie do oceny jest różne od zobowiazań ustanowionych $w$ art. 4-7, 10 i 11 dyrektywy 85/337, które zasadniczo sq zobowiqzaniami do zbierania $i$ wymiany informacji, konsultowania, upubliczniania i zagwarantowania istnienia środka zaskarżenia. Chodzi tu o przepisy proceduralne, które dotyczq jedynie wdrażania podstawowego zobowiqzania ustanowionego $w$ art. 3 tej dyrektywy ${ }^{64}$.

Rozwijając to stanowisko Trybunał dodał, że art. 8 tej dyrektywy stanowi, że wyniki konsultacji i informacje zebrane zgodnie z jej art. 5-7 muszq być uwzględnione $w$ procedurze wydania zezwolenia. Jednakize tego zobowiqzania uwzględnienia przed zakończeniem procesu podejmowania decyzji informacji zebranych przez wtaściwy organ środowiskowy nie można mylić ze zobowiqzaniem oceny natożonym $w$ art. 3 dyrektywy 85/337. Owa ocena bowiem, której należy dokonać przed procesem podejmowania decyzji (wyrok z dnia 4 maja 2006 r. w sprawie C-508/03 Komisja przeciwko Zjednoczonemu Królestwu, Zb. Orz. TE I-3969, par. 103), pociaga za sobq badanie co do istoty zebranych informacji, jak również rozważenie możliwości ich ewentualnego uzupetnienia dodatkowymi danymi. Ten właściwy organ środowiskowy powinien więc oddać się zarówno pracy dochodzeniowej, jak i analizie, aby dokonać jak najpetniejszej analizy bezpośrednich i pośrednich skutków rozpatrywanego przedsięwzięcia na elementy wymienione $w$ trzech pierwszych tiret wspomnianego art. 3 oraz wzajemnych oddziatywań między nimi. Z brzmienia rozpatrywanych przepisów przywo- 
tanej dyrektywy i z jej ogólnej systematyki wynika więc, że jej art. 3 stanowi podstawowy przepis. Zwykła transpozycja art. 4-11 tej dyrektywy nie może być uznana za dokonujacca automatycznie transpozycji tego art. $3^{65}$.

W odniesieniu do drugiego zarzutu ze skargi Komisji Trybunał stwierdził, że kwestionuje ona dokonanie transpozycji art. 2-4 dyrektywy 85/337 $w$ uregulowaniach irlandzkich ze względu na to, że procedury ustanowione przez te uregulowania nie gwarantuja petnego poszanowania wspomnianych artykutów, gdy wiele organów krajowych uczestniczy $w$ procesie podejmowania decyzji. W zwiqzku z powyższym należy z góry odrzucić argumentację Irlandii, zgodnie z którq Komisja nie wskazała w wystarczający sposób podstawy faktycznej swej skargi. Mianowicie-jak podniosta Komisja-ponieważ przedmiotem skargi o stwierdzenie uchybienia zobowiązaniom państwa członkowskiego jest sposób dokonania transpozycji dyrektywy 85/337 a nie konkretny wynik stosowania krajowych uregulowań dotyczacych tej transpozycji, należy zbadać, czy wspomniane uregulowania same w sobie niewystarczajaco lub nieprawidłowo dokonujq transpozycji tej dyrektywy, jak twierdzi Komisja, bez konieczności wykazywania rzeczywistych skutków dokonujacych transpozycje uregulowań krajowych $w$ odniesieniu do konkretnych przedsięwzięć (zob. ww. wyrok z dnia 20 listopada 2008 r. w sprawie Komisja przeciwko Irlandii, pkt 59) ${ }^{66}$.

Następnie Trybunał przypomniał, że art. 1 ust. 2 dyrektywy 85/337 definiuje termin „zezwolenie na inwestycje” jako decyzje właściwej władzy lub władz, na podstawie której wykonawca otrzymuje prawo do wykonania przedsięwzięcia. Artykuł 1 ust. 3 wyjaśnia, ̇̇e właściwq władzq lub władzami jest lub sq te wyznaczone przez państwa członkowskie, które sq odpowiedzialne za wykonywanie obowiqzków wynikajacych z tej dyrektywy. W ramach pozostawionej państwom członkowskim $w$ ten sposób swobody określenia organów właściwych do wydania zezwolenia $w$ rozumieniu wspomnianej dyrektywy mogq one zdecydować o powierzeniu tego zadania wielu jednostkom, co Komisja zreszta wyraźnie przyznała. Artykuł 2 ust. 2 dyrektywy 85/337 dodaje, iz ocena oddziatywania

65 Sprawa C-50/09, par. 39-41.

66 Sprawa C-50/09, par. 69-70. 
na środowisko może być zintegrowana z istniejacymi procedurami udzielania zezwolenia na przedsięwzięcia $w$ państwach członkowskich lub, jeżeli takie nie istnieja, z innymi procedurami albo z procedurami, które będq ustanowione do realizacji celów tej dyrektywy. Z przepisu tego wynika, że swoboda decyzyjna przystugująca państwom członkowskim obejmuje określenie przepisów proceduralnych $i$ warunków udzielenia rozpatrywanego zezwolenia. Jednakże ze swobody tej można korzystać jedynie $w$ granicach ustalonych we wspomnianej dyrektywie i o ile wybory dokonane przez państwa członkowskie gwarantuja petne przestrzeganie ustanowionych $w$ niej celów ${ }^{67}$.

Zdaniem więc Trybunału, art. 2 ust. 1 dyrektywy 85/337 wskazuje zatem, że ocena oddziaływania na środowisko powinna mieć miejsce „przed udzieleniem zezwolenia”. Oznacza to, że ocena bezpośrednich i pośrednich skutków przedsięwzięcia na elementy określone $w$ art. 3 tej dyrektywy i na wzajemne oddziatywanie między tymi elementami jest przeprowadzana całkowicie przed wspomnianym udzieleniem zezwolenia. W tych okolicznościach, chociaż nic nie stoi na przeszkodzie, aby Irlandia dokonała wyboru powierzenia realizacji celów wspomnianej dyrektywy dwóm odmiennym organom, tzn. z jednej strony organom ds. zagospodarowania terenu, a z drugiej strony agencji, to może ona dokonać tego wyboru pod warunkiem, iz odpowiednie kompetencje tych organów $i$ zasady dotyczqce ich wdrażania gwarantuja, że ocena oddziatywania na środowisko jest dokonywana $w$ wyczerpujacy sposób $i$ we właściwym czasie, tzn. przed udzieleniem zezwolenia w rozumieniu tej dyrektywy ${ }^{68}$.

Przekładając powyższe ustalenia na grunt rozwiązań przyjętych przez Irlandię celem transpozycji tej dyrektywy Trybunał przyznał rację Komisji, która zwracała uwagę na lukę istniejącą w tym zakresie w przepisach prawa irlandzkiego. Według Komisji luka ta wynikała z dwóch czynników: pierwszym z nich jest brak jakiegokolwiek prawa agencji, gdy wptynat do niej wniosek o udzielenie zezwolenia na przedsięwzięcie w świetle aspektów związanych z zanieczyszczeniem, wszczęcia oceny oddziaływania na środowi- 
sko. Drugim czynnikiem jest możliwość złożenia wniosku do agencji i możliwość, ̇̇e wyda ona decyzje w sprawie kwestii zanieczyszczenia, zanim zostanie złożony wniosek do organu ds. zagospodarowania przestrzennego, który jako jedyny ma prawo wymagać od wykonawcy przedstawienia raportu dotyczacego oddziaływania na środowisko. Trybunał rozważył wyjaśnienia przedstawione w tym zakresie przez Irlandię, jednakże doszedł ostatecznie do wniosku, że nie można wykluczyć, że agencja ochrony środowiska jako organ zobowiązany do wydania decyzji w sprawie zezwolenia na przedsięwzięcie w świetle aspektów związanych z zanieczyszczeniem podejmie odpowiednią decyzję również w sytuacji, gdy ocena oddziaływania na środowisko zgodnie z art. 2-4 dyrektywy 85/337 nie została przeprowadzona. Trybunał odrzucił tłumaczenia Irlandii, że w niektórych przypadkach dotyczących w szczególności wniosków o zezwolenie na odzyskiwanie i usuwanie odpadów, jak również wniosków o zezwolenie na zintegrowaną kontrolę i zapobieganie zanieczyszczeniom agencja miała możliwość żądania raportu dotyczącego oddziaływania na środowisko (którym była też jednocześnie związana). W ocenie Trybunału takich szczegółowych zasad nie można było uznać za wypełniające wskazaną wyżej lukę w przepisach irlandzkich, podobnie jak nie można tego osiągnąć przez przyznanie organom ds. zagospodarowania kompetencji w taki sposób, że nakładały się one w pewnych przypadkach na kompetencje agencji. Z tych względów Trybunał uznał drugi zarzut Komisji za zasadny ${ }^{69}$.

Trzeci zarzut Komisji dotyczył wyłączenia z zakresu pojęcia „przedsięwzięcie” z art. 1 ust. 2 dyrektywy 85/337 robót rozbiórkowych. W ocenie Komisji roboty rozbiórkowe mogq stanowić „przedsięwzięcie” $w$ rozumieniu art. 1 ust. 2 dyrektywy 85/337, gdyż wchodzq one $w$ zakres pojęcia ,innych interwencji w otoczeniu naturalnym i krajobrazie". Tymczasem $w$ PDR Irlandia zwolnita prawie wszystkie roboty rozbiórkowe z obowiazku dokonania oceny oddziaływania na środowisko ${ }^{70}$.

69 Sprawa C-50/09, par. 78, 81-85.

70 Sprawa C-50/09, par. 86. 
Przystępując do oceny argumentów przedłożonych przez strony tego sporu, Trybunał wskazał, że należy zaznaczyć od razu, ̇̇e definicja terminu „przedsięwzięcie” znajdująca się $w$ art. 1 ust. 2 tej dyrektywy nie pozwala na wyciagnięcie wniosku, że roboty rozbiórkowe nie mogty spetniać kryteriów tej definicji. Takie prace moga bowiem zostać zakwalifikowane jako „inne interwencje $w$ otoczeniu naturalnym i krajobrazie". Ta wykładnia poparta jest faktem, ̇̇e $w$ przypadku gdy roboty rozbiórkowe bytyby wyłaczone z zakresu stosowania wspomnianej dyrektywy, odwołania do „dziedzictwa kultury” w jej art. 3, do „krajobrazów o znaczeniu historycznym, kulturalnym lub archeologicznym" $w$ pkt 2 lit. $h$ ) zatacznika III do tej dyrektywy i do „dziedzictwa architektonicznego i archeologicznego" w pkt 3 załacznika IV do niej, bytyby bezprzedmiotowe $^{71}$.

Trybunał zaznaczył również, że zgodnie z art. 4 dyrektywy 85/337, aby przedsięwzięcie wymagało dokonania oceny oddziatywania na środowisko, musi wchodzić do jednej z kategorii wymienionych $w$ zatacznikach I i II do tej dyrektywy. Tymczasem, jak twierdzi Irlandia, nie zawieraja one wyraźnego odniesienia do robót rozbiórkowych z wyjątkiem, pozbawionym znaczenia dla niniejszej sprawy, demontażu elektrowni jądrowych $i$ innych reaktorów jądrowych, o którym mowa w pkt 2 załacznika I. Zdaniem Trybunału należy jednakże uwzględnić fakt, że te załaczniki dotyczq raczej sektorowych kategorii przedsięwzięć, nie opisując dokładnego charakteru przewidzianych robót. Dla przykładu można zaznaczyć, jak dokonata tego Komisja, ̇̇e „przedsięwzięcia inwestycyjne na obszarach miejskich" wymienione w pkt 10 lit. b) wspomnianego załacznika II bardzo często obejmuja zniszczenie istniejących budowli. Wynika stad, że roboty rozbiórkowe objęte sq zakresem stosowania wspomnianej dyrektywy i z tego tytutu moga stanowić „przedsięwzięcie” $w$ rozumieniu jej art. 1 ust. $2^{72}$.

912011 Sprawa C-50/09, par. 97-98.

72 Sprawa C-50/09, par. 99-101. 
VII.2. WYROK TRYBUNAŁU Z DNIA 17 MARCA 2011 R.

\section{W SPRAWIE C-275/09 BRUSSELS HOOFDSTEDELIJK GEWEST I INNI PRZECIWKO VLAAMSE GEWEST ${ }^{73}$}

Artykuł 1 ust. 2 tiret drugie i pkt 7 załącznika I do dyrektywy Rady 85/337/EWG z dnia 27 czerwca 1985 r. w sprawie oceny skutków wywieranych przez niektóre przedsięwzięcia publiczne i prywatne na środowisko naturalne, zmienionej dyrektywą Rady 97/11/WE z dnia 3 marca 1997 r., należy interpretować w ten sposób, że:

- odnowienie istniejącego pozwolenia na eksploatację portu lotniczego przy braku robót lub interwencji zmieniających stan fizyczny miejsca nie może być zakwalifikowane jako „przedsięwzięcie” lub „budowa” w rozumieniu tych przepisów;

- sąd krajowy powinien jednak ustalić na podstawie mającego zastosowanie uregulowania krajowego i ewentualnie $\mathrm{z}$ uwzględnieniem łącznego rezultatu szeregu robót lub interwencji zrealizowanych od czasu wejścia w życie tej dyrektywy, czy pozwolenie to nie stanowi części wieloetapowej procedury zatwierdzającej, której celem ostatecznym jest przeprowadzenie działań stanowiących przedsięwzięcie w rozumieniu pkt 13 tiret pierwsze załącznika II w związku z pkt 7 załącznika I do tej dyrektywy. W przypadku nieprzeprowadzenia oceny oddziaływania takich robót lub interwencji na środowisko na wcześniejszym etapie procedury zatwierdzającej sąd krajowy powinien zapewnić skuteczność dyrektywy, czuwając nad tym, by taka ocena została przeprowadzona przynajmniej na etapie wydania pozwolenia na eksploatację.

W sprawie C-275/09 z pytaniami prejudycjalnymi do Trybunału zwrócił się sąd krajowy - Raad van State (Belgia), na tle rozstrzyganego sporu między Brussels Hoofdstedelijk Gewest

3 http://curia.eu; dalej cyt.: sprawa C-275/09. 
(region Bruksela-Stolica) i szeregiem innych skarżących a Vlaams Gewest (regionem flamandzkim) w przedmiocie decyzji dotyczącej eksploatacji portu lotniczego Bruxelles-National. Okoliczności faktyczne w sprawie przedstawiały się następująco. W 2004 r. The Brussels Airport Company NV złożył wniosek o pozwolenie środowiskowe w celu kontynuacji eksploatacji portu lotniczego Bruxelles-National i jego modyfikacji obejmującej powiększenie o kolejne działki. Eksploatacja portu objęta jest obowiązkiem pozwoleniowym od 1999 r., a pierwsze pozwolenie wydano w roku 2000 i było ono następnie zmieniane trzykrotnie (brak danych o przeprowadzeniu oceny oddziaływania na środowisko). Organ wydający pozwolenie (stałe przedstawicielstwo rady prowincji Brabancji flamandzkiej) w swojej decyzji adresowanej do The Brussels Airport Company NV zezwolił na dalszą eksploatację tego portu lotniczego, nie zgadzając się jednakże na jego powiększenie. W odwołaniu od tej decyzji skarżący wskazali w szczególności, że do wniosku o pozwolenie środowiskowe powinna być załączona ocena oddziaływania na środowisko. Organ drugiej instancji (flamandzki minister robót publicznych, energii, środowiska i przyrody) utrzymał w mocy decyzję stałego przedstawicielstwa. Brussels Hoofdstedelijk Gewest i szereg innych skarżących wniosło do Raad van State skargę na decyzję ministra, jako wadliwą z uwagi na wydanie pozwolenia środowiskowego bez wypełnienie obowiązku przeprowadzenia oceny oddziaływania na środowisko ${ }^{74}$.

Trybunał, uznając że pytania sądu krajowego należy rozpatrzyć łącznie, ocenił, że w sprawie C-275/09 kluczową kwestią jest ustalenie, czy eksploatacja portu lotniczego może stanowić „przedsięwzięcie” w rozumieniu art. 1 ust. 2 dyrektywy 85/337, a w przypadku odpowiedzi twierdzącej - czy przedsięwzięcie to należy do przedsięwzięć wymienionych w załącznikach I i II do tej dyrektywy. Trybunał przypomniał więc, iż z samego brzmienia art. 1 ust. 2 dyrektywy 85/337 wynika, że pojęcie „przedsięwzięcia" odnosi się do robót i interwencji materialnych (zob. par. 23 
wyroku z dnia 28 lutego 2008 r. w sprawie C-2/07 Abraham i in., Zb. Orz. TE I-1197) $)^{75}$.

W ocenie Trybunału, w sporze przed sądem krajowym działanie, którego dotyczy ten spór, ograniczał się do odnowienia istniejącego pozwolenia na eksploatację portu lotniczego Bruxelles-National, nie dotyczył natomiast dokonywania jakichkolwiek robót lub interwencji zmieniających stan fizyczny tego miejsca. Trybunał nie zgodził się przy tym $\mathrm{z}$ argumentacją skarżących co do tego, że pojęcie interwencji materialnej należy interpretować rozszerzająco w rozumieniu każdej interwencji w środowisku naturalnym. Trybunał stanął na stanowisku, że odnowienie istniejącego pozwolenia na eksploatację portu lotniczego, przy braku robót lub interwencji zmieniających stan fizyczny miejsca, nie może być zakwalifikowane jako „przedsięwzięcie” w rozumieniu art. 1 ust. 2 tiret drugie dyrektywy 85/337 ${ }^{76}$.

Jednocześnie Trybunał przedstawił szeroko swoje stanowisko co do objęcia przedsięwzięć mogących znacząco oddziaływać na środowisko procedurą oceny oddziaływania. Wskazał m.in., że art. 2 ust. 1 dyrektywy 85/337 nie wymaga $w$ każdym razie, aby procedurze oceny przewidzianej $w$ tej dyrektywie podlegaty wszelkie przedsięwzięcia mogqce znaczqco oddziaływać na środowisko, lecz jedynie te przedsięwzięcia, które wymieniono $w$ załacznikach I i II do dyrektywy (postanowienie z dnia 10 lipca 2008 r. $w$ sprawie C-156/07 Aeillo i in., Zb. Orz. TE I-5215, par. 34). Ponadto, w ocenie Trybunału, pojęcie budowy użyte $w$ pkt 7 lit. a) załacznika I do dyrektywy 85/337 nie przedstawia żadnej niejasności i że należy je rozumieć $w$ jego obiegowym znaczeniu, to znaczy jako odnoszacym się do wykonywania wcześniej nieistniejacych budowli bqqdź do materialnej zmiany już istniejących budowli. Trybunał przyznał wprawdzie, że $w$ swym orzecznictwie dokonat szerokiej wykładni pojęcia budowy, uznajac, że roboty $w$ zakresie przebudowy istniejącego pasa startowego mogq ze względu na ich zakres i charakterystykę odpowiadać budowie nowego pasa (wyrok $z$ dnia 25 lipca 2008 r. w sprawie C-142/07 Ecologistas en Acción-CODA, Zb. Orz. TE I-6097, par. 36). Podobnie Trybunat dokonat

75 Sprawa C-275/09, par. 19-20.

76 Sprawa C-275/09, par. 21-22, 24. 
wykładni pkt 13 załacznika II do dyrektywy 85/337 w zwiazku z pkt 7 zatacznika I do tej dyrektywy $w$ ten sposób, że dotyczq one również robót zwiqzanych ze zmianq infrastruktury istniejacego portu lotniczego bez przedtużenia pasa startowego, o ile moga one zostać uznane za zmianę samego portu lotniczego ze względu w szczególności na ich rodzaj, zakres i charakterystykę (ww. wyrok $w$ sprawie Abraham i in., pkt 40) ${ }^{77}$. Z uwagi jednak na to, że w sprawie C-275/09 pozwolenie nie miało dotyczyć robót tego rodzaju, Trybunał uznał, iż $w \dot{z}$ adnym wypadku odnowienie istniejacego pozwolenia na eksploatacje portu lotniczego w obliczu braku robót lub interwencji zmieniających stan fizyczny miejsca nie może być zakwalifikowane jako „budowa” $w$ rozumieniu pkt 7 lit. a) zatacznika I do dyrektywy 85/33778.

Przystępując do rozpatrywania problemu objęcia wskazanego przedsięwzięcia oceną oddziaływania na środowisko, Trybunał przypomniał w pierwszym rzędzie, iż pozwolenie, które tak jak pozwolenie rozpatrywane $w$ postępowaniu przed sqdem krajowym nie dotyczy formalnie działalności podlegającej ocenie oddziaływania na środowisko $w$ rozumieniu załacznika I i II do dyrektywy 85/337, może jednak wymagać przeprowadzenia takiej oceny, jeżeli środek ten stanowi etap procedury prowadzqcej ostatecznie do zezwolenia na dziatalność stanowiaca przedsięwzięcie $w$ rozumieniu art. 2 ust. 1 tej dyrektywy (zob. podobnie ww. wyrok $w$ sprawie Abraham i in., pkt 25). [...]Gdy prawo krajowe przewiduje, że procedura udzielenia zezwolenia na inwestycję odbywa się $w$ kilku etapach, ocena oddziatywania przedsięwzięcia na środowisko powinna, co do zasady, zostać przeprowadzona już wtedy, gdy możliwe jest określenie i oszacowanie wszystkich skutków, jakie przedsięwzięcie to może wywierać na środowisko (zob. wyrok z dnia 7 stycznia 2004 r. w sprawie C-201/02 Wells, Zb. Orz. TE I-723, par. 53; ww. wyrok $w$ sprawie Abraham i in., par. 26). W tym względzie orzeczono również, że przepis krajowy przewidujacy, $i \dot{z}$ ocena oddziaływania przedsięwzięcia na środowisko może być dokonana wyłacznie na wstępnym etapie procedury zatwierdzającej, nie zaś na jej późniejszym etapie, nie jest zgodna 
z dyrektywq 85/337 (zob. podobnie wyrok z dnia 4 maja $2006 r$. $w$ sprawie C-508/03 Komisja przeciwko Zjednoczonemu Królestwu, Zb. Orz. TE I-3969, par. 105, 106) ${ }^{79}$.

Następnie Trybunał stwierdził, że do sądu krajowego należy ustalenie, czy na podstawie majacego zastosowanie uregulowania krajowego, czy decyzja taka jak będqca przedmiotem zawistej przed nim sprawy może zostać uznana za etap procedury zatwierdzającej składającej się z wielu etapów, której celem ostatecznym jest przeprowadzenie działań stanowiacych przedsięwzięcie $w$ rozumieniu właściwych przepisów dyrektywy 85/337. Ponadto Trybunał dodał, że w jego ocenie roboty zmieniajace infrastrukture istniejacego portu lotniczego bez przedtużenia pasa startowego objęte sq przepisami pkt 13 załacznika II dyrektywy 85/337 w zwiqzku z pkt 7 zataccznika I do niej, o ile ze względu w szczególności na ich rodzaj, zakres i charakterystykę mogq one zostać uznane za zmianę samego portu lotniczego (ww. wyrok w sprawie Abraham i in., par. 40). [...]Celu regulacji unijnej nie wolno omijać poprzez dzielenie przedsięwzięć oraz że nieuwzględnienie ich tącznego rezultatu nie może skutkować w praktyce wyłączeniem ich $w$ catości z obowiąku poddania ocenie, wówczas gdy rozpatrywane łącznie mogq znaczqco oddziaływać na środowisko w rozumieniu art. 2 ust. 1 dyrektywy 85/337 (ww. wyrok w sprawie Abraham i in., pkt 27). Gdyby okazało się, że od czasu wejścia w życie dyrektywy 85/337 na terenie portu lotniczego zostaty wykonane bez przeprowadzenia oceny ich oddziaływania na środowisko na wcześniejszym etapie procedury zatwierdzajacej roboty lub interwencje materialne, które należy uznać za przedsięwzięcie w rozumieniu tej dyrektywy, sqad krajowy powinien uwzględnić to na etapie wydania zezwolenia na eksploatację i zapewnić skuteczność tej dyrektywy, czuwając nad tym, by taka ocena została przeprowadzona przynajmniej na tym etapie ${ }^{80}$.

79 Sprawa C-275/09, par. 32-33.

80 Sprawa C-275/09, par. 34-37. 


\section{VII.3. WYROK TRYBUNAŁU Z DNIA 24 MARCA 2011 R. W SPRAWIE C-435/09 KOMISJA EUROPEJSKA PRZECIWKO KRÓLESTWU BELGII ${ }^{81}$}

Przedmiot: uchybienie zobowiązaniom państwa członkowskiego - nieprawidłowa i niepełna transpozycja dyrektywy Rady 85/337/EWG z dnia 27 czerwca 1985 r. w sprawie oceny skutków wywieranych przez niektóre przedsięwzięcia publiczne i prywatne na środowisko naturalne, zmienionej dyrektywą Rady 97/11/EWG z dnia 3 marca 1997 r. - artykuł 4 ust. 2 i 3 w związku z załącznikami II i III (Wspólnota flamandzka), art. 4 ust. 1 w związku z załącznikiem I pkt 8 lit. a) i pkt 18 lit. a) i art. 7 ust. 1 lit. b) (Region Waloński) oraz art. 4 ust. 2 i 3 w związku z załącznikami II i III (Region Stołeczny Brukseli) - progi i kryteria.

Sentencja:

1) Ze względu na fakt, że nie przyjęto niezbędnych środków w celu prawidłowego i całkowitego wykonania:

- w odniesieniu do uregulowań Regionu Flamandzkiego, art. 4 ust. 2 i 3 dyrektywy Rady 85/337/EWG z dnia 27 czerwca 1985 r. w sprawie oceny skutków wywieranych przez niektóre przedsięwzięcia publiczne i prywatne na środowisko naturalne zmienionej dyrektywą 2003/35/WE Parlamentu Europejskiego i Rady z dnia 26 maja 2003 r. w związku z załącznikami II i III do tej dyrektywy,

- w odniesieniu do uregulowań Regionu Walońskiego, art. 4 ust. $1 \mathrm{w}$ związku z załącznikiem I pkt 8 lit. a) i pkt 18 lit. a) dyrektywy 85/337 zmienionej dyrektywą 2003/35 i art. 7 ust. 1 lit. b) tej dyrektywy, oraz,

- w odniesieniu do uregulowań Regionu Stołecznego Brukseli, art. 4 ust. 2 i 3 w związku z załącznikami II i III dyrektywy 85/337 zmienionej dyrektywą 2003/35 i załącznika III jako takiego,

81 Dz. Urz. UE C 152 z 21.05.2011, s. 6-7; uzasadnienie wyroku dostępne jedynie we flamandzkiej i francuskiej wersji językowej. 
Królestwo Belgii uchybiło zobowiązaniom, które na nim ciążą na mocy tej dyrektywy.

2) Królestwo Belgii zostaje obciążone kosztami postępowania.

\section{VII.4. WYROK TRYBUNALU Z DNIA 12 MAJA 2011 R.}

\section{W SPRAWIE C-115/09 BUND FÜR UMWELT UND NATURSCHUTZ DEUTSCHLAND, LANDESVERBAND NORDRHEIN-WESTFALEN EV PRZECIWKO BEZIRKSREGIERUNG ARNSBERG ${ }^{82}$}

1) Artykuł 10a dyrektywy Rady 85/337/EWG z dnia 27 czerwca 1985 r. w sprawie oceny skutków wywieranych przez niektóre przedsięwzięcia publiczne i prywatne na środowisko naturalne, zmienionej dyrektywą 2003/35/WE Parlamentu Europejskiego i Rady z dnia 26 maja 2003 r. sprzeciwia się przepisom, które nie przyznają organizacji pozarządowej działającej na rzecz ochrony środowiska, o której mowa w art. 1 ust. 2 tej dyrektywy, możliwości powołania się przed sądem w ramach środka prawnego przeciwko decyzji w sprawie zezwolenia na przedsięwzięcia mogące ,znacząco oddziaływać na środowisko" w rozumieniu art. 1 ust. 1 dyrektywy 85/337, zmienionej dyrektywą 2003/35, na naruszenie przepisu wynikającego $\mathrm{z}$ prawa Unii i mającego za przedmiot ochronę środowiska, $\mathrm{z}$ uwagi na to, że przepis ten chroni tylko interesy ogółu, a nie interesy jednostek.

2) Taka organizacja pozarządowa może wywodzić $\mathrm{z}$ art. 10a akapit trzeci zdanie ostatnie dyrektywy $85 / 337$, zmienionej dyrektywą $2003 / 35$, prawo do powołania się przed sądem $\mathrm{w}$ ramach środka prawnego przeciwko decyzji w sprawie zezwolenia na przedsięwzięcia mogące „znacząco oddziaływać na środowisko naturalne" w rozumieniu art. 1 ust. 1 dyrektywy

82 http://curia.eu; dalej cyt.: sprawa C-115/09. 
85/337, ze zmianami, na naruszenie uregulowań prawa krajowego wynikających z art. 6 dyrektywy 92/43/EWG z dnia 21 maja 1992 r. w sprawie ochrony siedlisk przyrodniczych oraz dzikiej fauny i flory, zmienionej dyrektywą Rady 2006/105/WE dnia 20 listopada 2006 r., chociaż nie dopuszcza do tego krajowe prawo procesowe, $\mathrm{z}$ uwagi na to, że przytoczone przepisy chronią tylko interesy ogółu, a nie interesy jednostek.

W sprawie C-115/09 z pytaniami prejudycjalnymi do Trybunału zwrócił się Oberverwaltungsgericht für das Land Nordrhein-Westfalen (wyższy sąd administracyjny dla kraju związkowego Nadrenii Północnej-Westfalii, Niemcy), przed którym toczył się spór między Bund für Umwelt und Naturschutz Deutschland, Landesverband Nordrhein-Westfalen eV (związkiem na rzecz środowiska naturalnego i ochrony przyrody, stowarzyszeniem z kraju związkowego Nadrenia Północna-Westfalia' ${ }^{83}$ ), a Bezirksregierung Arnsberg dotyczącego zezwolenia przyznanego przez tę ostatnią Trianel Kohlekraftwerk GmbH \& Co. KG na budowę i eksploatację elektrowni opalanej węglem kamiennym w Lünen ${ }^{84}$.

Okoliczności sporu przed sądem krajowym przedstawiały się następująco. Trianel zamierzała wybudować i eksploatować elektrownię opalaną węglem kamiennym w Lünen, której oddanie przewidywano na rok 2012. Miejsce usytuowania tej elektrowni znajdowało się w odległości $8 \mathrm{~km}$ od 5 obszarów chronionych w rozumieniu dyrektywy siedliskowej. Decyzję wstępną w tym przedmiocie, której adresatem była Trianel, wydał w 2008 r. w ramach postępowania w sprawie oceny skutków dla środowiska tego przedsięwzięcia Bezirksregierung Arnsberg, udzielając pierwszego częściowego zezwolenia na przedsięwzięcie i stwierdzając, że nie istniały żadne zastrzeżenia prawne co do przedsięwzięcia. Skargę o uchylenie decyzji do Oberverwaltungsgericht für das Land Nordrhein-Westfalen wniósł związek na rzecz środowiska naturalnego, argumentując że doszło do

83 Dalej cyt.: związek na rzecz środowiska naturalnego.

84 Sprawa C-115/09, par. 2. 
naruszenia przepisów dotyczących transpozycji dyrektywy siedliskowej ${ }^{85}$, a w szczególności jej art. $6^{86}$.

Trybunał stwierdził, że w dwóch pierwszych pytaniach, sąd krajowy daży do ustalenia, czy art. 10a dyrektywy 85/337 sprzeciwia się przepisom, które nie przyznajq organizacjom pozarząowym działajacym na rzecz ochrony środowiska, o których mowa w art. 1 ust. 2 dyrektywy 85/337 (zwanym dalej „stowarzyszeniami ochrony środowiska"), możliwości powołania się przed sq̨dem $w$ ramach środka prawnego przeciwko decyzji $w$ sprawie zezwolenia na przedsięwzięcia mogqce „znaczaco oddziaływać na środowisko" $w$ rozumieniu art. 1 ust. 1 dyrektywy 85/337 na naruszenie uregulowania, które chroni tylko interesy ogótu, a nie interesy jednostek. Sąd krajowy zwraca się do Trybunatu również o ustalenie, czy art. 10a dyrektywy 85/337 sprzeciwia się takiemu ustawodawstwu ogólnie, czy też wyłącznie w zakresie, w jakim ustawodawstwo to nie umożliwia tej organizacji powotywania się przed sadem na konkretne przepisy prawa ochrony środowiska pochodzenia wspólnotowego lub czysto krajowego. Z postanowienia odsyłajacego wynika, że pytanie to uzasadnione jest okolicznościq, iz obowiązujące ustawodawstwo krajowe uzależnia dopuszczalność skargi takiej jak wniesiona przez skarżacego $w$ postępowaniu przed sqdem krajowym od tego, by skarżacy podnióst, iż zaskarżona decyzja administracyjna narusza indywidualne prawo, które można zgodnie z prawem krajowym uznać za publiczne prawo podmiotowe ${ }^{87}$.

Przystępując do analizy problemu, Trybunał zaznaczył na wstępie, że art. 10a akapit pierwszy dyrektywy 85/337 przewiduje, iż powinna istnieć możliwość wniesienia środka prawnego do sqdu przeciwko decyzjom, aktom lub zaniechaniom, o których mowa $w$ tym artykule, aby „zakwestionować [ich] materialnq i proceduralnq legalność", bez ograniczania w jakikolwiek sposób zarzutów, na które można powołać się w uzasadnieniu takiego środka. Jeśli chodzi o przesłanki dopuszczalności środków prawnych, przepis ten

85 Dyrektywa Rady 92/43/EWG z dnia 21 maja 1992 r. w sprawie ochrony siedlisk przyrodniczych oraz dzikiej fauny i flory, Dz. Urz. UE L 206 z 22.7.1992, s. 7-50, ze zm.

86 Sprawa C-115/09, par. 24-26.

87 Sprawa C-115/09, par. 35-36. 
przyjmuje dwa założenia: dopuszczalność środka prawnego może być uzależniona od „wystarczajacego interesu” lub od powołania się przez skarżacego na „naruszenie prawa”, w zależności od tego, którq z tych dwóch przestanek przewiduje ustawodawstwo krajowe. Wartykule 10a akapit pierwszy zdanie pierwsze dyrektywy 85/337 sprecyzowano następnie, że państwa członkowskie zobowiqzane sq do ustalenia, co stanowi naruszenie prawa, zgodnie z celem udzielenia zainteresowanej społeczności „szerokiego dostępu do wymiaru sprawiedliwości". Względem środków prawnych wniesionych przez stowarzyszenia ochrony środowiska art. 10a akapit trzeci zdanie drugie i trzecie dyrektywy 85/337 dodaje, że $w$ tym celu powinny one być uznane za majace wystarczający interes lub posiadajace prawa, które mogq zostać naruszone, w zależności od tego, którq z tych dwóch przesłanek dopuszczalności przewiduje ustawodawstwo krajowe ${ }^{88}$.

$\mathrm{W}$ ocenie Trybunału, te różne przepisy należy interpretować $w$ świetle i przy uwzględnieniu celów konwencji z Aarhus, do której, jak wynika z motywu 5 dyrektywy 2003/35, powinno być „właściwie dopasowane” prawo Unii. Z powyższego wynika, ̇̇e bez względu na opcję wybranq przez państwo członkowskie w odniesieniu do dopuszczalności środków prawnych stowarzyszenia ochrony środowiska maja prawo zgodnie z art. 10a dyrektywy 85/337 do wniesienia środka prawnego do sq̨du lub innego niezależnego i bezstronnego organu ustanowionego przez prawo, by zakwestionować materialnq i proceduralnq legalność decyzji, aktów lub zaniechań, o których mowa $w$ tym artykule. Wreszcie należy przypomnieć, że kiedy $w$ braku uregulowań ustanowionych $w$ tej dziedzinie przez prawo Unii do porzqdku prawnego każdego państwa członkowskiego należy wyznaczenie właściwych sq̨ów i określenie zasad postępowania $w$ sprawach majacych za przedmiot ochronę uprawnień podmiotów prawa wynikajacych z prawa Unii, te zasady nie moga być mniej korzystne od zasad odnoszacych się do odpowiednich środków prawnych dotyczacych wyłacznie prawa krajowego (zasada równoważności) i nie moga powodować w praktyce, że korzysta- 
nie z uprawnień wynikajacych z prawa Unii stanie się niemożliwe lub nadmiernie utrudnione (zasada skuteczności) ${ }^{89}$.

Mając powyższe na względzie Trybunał jednoznacznie wskazał, że chociaż do państw członkowskich należy określenie, gdy taki jest ich porzqdek prawny, jakie sq prawa, których naruszenie może być przedmiotem zaskarżenia $w$ dziedzinie środowiska naturalnego, w granicach określonych przez art. 10a dyrektywy 85/337, nie mogq one, dokonując tego określenia, pozbawić stowarzyszeń ochrony środowiska, które spetniajq wymogi wymienione $w$ art. 1 ust. 2 tej dyrektywy, moziliwości odgrywania roli przystugującej jej zarówno zgodnie z dyrektywq 85/337, jak i zgodnie z konwencja z Aarhus. W odniesieniu do takich przepisów jak przepisy rozpatrywane $w$ postępowaniu przed sqdem krajowym - jeśli dopuszczalne jest, żeby ustawodawca krajowy ograniczał prawa, których naruszenie może być podnoszone przez jednostke $w$ ramach skargi do sqdu na decyzje, akty lub zaniechania wspomniane $w$ art. 10a dyrektywy 85/337, tylko do praw podmiotowych zainteresowanej społeczności, takie ograniczenie nie może być zastosowane jako takie do stowarzyszeń ochrony środowiska, $w$ przeciwnym razie naruszy to art. 10a akapit trzeci zdanie ostatnie dyrektywy $85 / 337^{90}$. Trybunał dodał również, że pojęcie „naruszenie prawa" nie może zależeć od warunków, które mogq być spetnione tylko przez inne osoby fizyczne lub prawne, takich jak np. warunek bycia blizssym lub dalszym sqsiadem instalacji lub warunek odczuwania $w$ ten czy inny sposób skutków jej działania. Wynika z tego w sposób bardziej ogólny, że art. 10a akapit trzeci zdanie ostatnie dyrektywy 85/337 należy rozumieć $w$ ten sposób, że wśród „praw, które moga być naruszone”, z których maja korzystać stowarzyszenia ochrony środowiska, powinny koniecznie znaleźć się przepisy prawa krajowego, które wprowadzaja w życie ustawodawstwo Unii $w$ dziedzinie ochrony środowiska, jak również przepisy prawa Unii $w$ zakresie ochrony środowiska mające bezpośredniq skuteczność. $W$ tym względzie $w$ celu udzielenia sqadowi krajowemu moziliwie

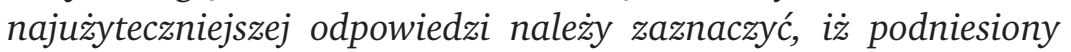
przeciwko zaskarżonej decyzji zarzut oparty na naruszeniu prze-

89 Sprawa C-115/09, par. 41-43.

90 Sprawa C-115/09, par. 44-45. 
pisów prawa krajowego wynikających z art. 6 „dyrektywy siedliskowej” może być zatem również podniesiony przez stowarzyszenie ochrony środowiska ${ }^{91}$.

$\mathrm{W}$ ramach trzeciego pytania prejudycjalnego sąd krajowy zwrócił się do Trybunału o wyjaśnienie, czy stowarzyszenie ochrony środowiska może wywodzić z art. 10a akapit trzeci zdanie ostatnie dyrektywy 85/337 prawo do powołania się przed sądem w ramach środka prawnego przeciwko decyzji w sprawie zezwolenia na przedsięwzięcia mogące „znacząco oddziaływać na środowisko" w rozumieniu art. 1 ust. 1 dyrektywy 85/337 na naruszenie przepisów prawa krajowego wynikającego z art. 6 „dyrektywy siedliskowej”, chociaż nie dopuszcza do tego krajowe prawo procesowe $\mathrm{z}$ uwagi na to, że przytoczone przepisy chronią tylko interesy ogółu, a nie interesy jednostek ${ }^{92}$.

Trybunał, po przypomnieniu swojego orzecznictwa w przedmiocie obowiązków organów sądowych państw członkowskich w zakresie wykładni efektywnej oraz stanowiska Trybunału co do zasady skutku bezpośredniego w prawie unijnym, stwierdził że art. 10a dyrektywy 85/337 rozpatrywany jako catość pozostawia państwom członkowskim znaczny zakres swobody $w$ celu ustalenia, co stanowi naruszenie prawa, jak i $w$ celu ustanowienia w szczególności przestanek dopuszczalności środków prawnych oraz organów, do których powinny być wnoszone. Nie dotyczy to jednak przepisów zawartych $w$ art. 10a akapit trzeci zdania przedostatnie $i$ ostatnie ${ }^{93}$. Zdaniem Trybunału przepisy te, przewidujac z jednej strony, że interes wszelkich organizacji pozarzqdowych spetniających wymogi określone $w$ art. 1 ust. 2 dyrektywy 85/337 uważa się za wystarczajacy, a z drugiej strony, że takie organizacje uważa się również za majace prawa, które moga być naruszone, stanowiq szczegótowe i niepodlegające innym warunkom uregulowania. Ponadto, jak zostato powiedziane powyżej, wśród praw, na które mogq powołać się przed sqdem zgodnie z art. 10a dyrektywy 85/337 stowarzyszenia ochrony środowiska, znajduja się przepisy wynikające z prawa Unii $w$ dziedzinie środowiska na-

91 Sprawa C-115/09, par. 47-49.

92 Sprawa C-115/09, par. 51.

93 Sprawa C-115/09, par. 55-56. 
turalnego, a w szczególności przepisy prawa krajowego wynikające z art. 6 dyrektywy siedliskowej ${ }^{94}$.

\section{OCHRONA PRZYRODY}

\section{VIII.1. WYROK TRYBUNAEU Z DNIA 15 LIPCA 2010 R. W SPRAWIE C-573/08 KOMISJA EUROPEJSKA PRZECIWKO REPUBLICE WŁOSKIEJ ${ }^{95}$}

Przedmiot: uchybienie zobowiązaniom państwa członkowskiego-naruszenie art. 2, 3, 4, 5, 6, 7, 9, 10, 11, 13 i 18 dyrektywy Rady 79/409/EWG z dnia 2 kwietnia 1979 r. w sprawie ochrony dzikiego ptactwa - niewłaściwa transpozycja - odstępstwa - wymogi.

Sentencja:

1) Ponieważ przepisy dokonujące transpozycji dyrektywy Rady 79/409/EWG z dnia 2 kwietnia 1979 r. w sprawie ochrony dzikiego ptactwa do włoskiego porządku prawnego nie są calkowicie zgodne $\mathrm{z}$ tą dyrektywą, a reżim transpozycji art. 9 nie gwarantuje, że odstępstwa przyjęte przez właściwe władze włoskie spełniają przesłanki i wymogi określone w tym przepisie, Republika Włoska uchybiła zobowiązaniom, które na niej ciążą na mocy art. 2-7, 9-11, 13 i 18 tej dyrektywy.

2) Republika Włoska zostaje obciążona kosztami postępowania, w tym kosztami postępowania w przedmiocie środka tymczasowego.

94 Sprawa C-115/09, par. 57-58.

Dz. Urz. UE C 246 z 11.09.2010, s. 3; uzasadnienie wyroku dostępne jedynie we włoskiej i francuskiej wersji językowej. 


\section{VIII.2. WYROK TRYBUNAŁU Z DNIA 14 PAŹDZIERNIKA 2010 R. W SPRAWIE C-535/07 KOMISJA EUROPEJSKA PRZECIWKO REPUBLICE AUSTRII ${ }^{96}$}

1) Republika Austrii:

- nie dokonując prawidłowo na podstawie kryteriów ornitologicznych klasyfikacji jako OSO terenu Hanság w kraju związkowym Burgenland i wytyczenia granic obszaru specjalnej ochrony Niedere Tauern w kraju związkowym Styria zgodnie z art. 4 ust. 1 dyrektywy Rady 79/409/EWG z dnia 2 kwietnia 1979 r. w sprawie ochrony dzikiego ptactwa oraz

- nie przyznając OSO Maltsch, Wiesengebiete im Freiwald, Pfeifer Anger, Oberes Donautal i Untere Traun w kraju związkowym Górna Austria, jak również OSO Verwall w kraju związkowym Vorarlberg ochrony prawnej zgodnej z wymogami art. 4 dyrektywy 79/409 i art. 6 ust. 2 dyrektywy Rady 92/43/EWG z dnia 21 maja 1992 r. w sprawie ochrony siedlisk przyrodniczych oraz dzikiej fauny i flory w związku z jej art. 7, uchybiła zobowiązaniom ciążącym na niej na mocy tych przepisów.

2) W pozostałym zakresie skarga zostaje oddalona.

3) Komisja Europejska, Republika Austrii i Republika Federalna Niemiec pokrywają własne koszty.

W 2001 r. Komisja zwróciła się do Republiki Austrii wzywając do usunięcia uchybienia, polegającego na tym, że Republika Austrii nie sklasyfikowała jako OSO najbardziej odpowiednich obszarów pod względem liczby i powierzchni, jak również nie zapewniła OSO należytej ochrony prawnej. W ocenie Komisji szczególne wątpliwości powstały w odniesieniu do wyznaczenia terenu Hanság i wytyczenia granic terenu Niedere Tauern ${ }^{97}$.

Odnosząc się do zarzutu Komisji dotyczącego naruszenia przepisów art. 4 ust. 1-2 dyrektywy ptasiej z powodu niesklasy-

96 http://curia.eu, dalej cyt.: sprawa C-535/07.

97 Sprawa C-535/07, par. 9. 
fikowania terenu Hanság jako OSO i nieprawidłowego wytyczenia granic OSO Niedere Tauern, Trybunał przypomniał, że art. 4 ust. 1 dyrektywy ptasiej nakłada na państwa członkowskie obowiqzek sklasyfikowania jako OSO najbardziej odpowiednich obszarów pod względem liczby i powierzchni dla zachowania gatunków wymienionych $w$ załącniku I do tej dyrektywy i że zgodnie z art. 4 ust. 2 państwa członkowskie klasyfikuja również jako OSO miejsca wylęgu, pierzenia i zimowania regularnie występujących gatunków wędrownych niewymienionych w tym załączniku, jak również miejsca postoju wzdluzi ich tras migracji (wyrok z dnia 6 marca 2003 r. $w$ sprawie C-240/00 Komisja przeciwko Finlandii, Zb. Orz. TE I-2187, par. 16) ${ }^{98}$. Co do niesklasyfikowania terenu terenu Hanság jako OSO, to został on sklasyfikowany po upływie terminu wyznaczonego w uzasadnionej opinii jako „europejski obszar ochrony" w drodze rozporządzenia rządu kraju związkowego Burgenland. Trybunał stosując ogólne zasady, zgodnie z którymi uchybienie powinno być oceniane $w$ zależności od sytuacji majacej miejsce $w$ państwie członkowskim $w$ momencie uptywu terminu wyznaczonego $w$ uzasadnionej opinii $i \dot{z}$ e zmiany, które nastapity w okresie późniejszym, nie mogq być uwzględniane przez Trybunał (zob. w szczególności wyrok z dnia 11 stycznia 2007 r. w sprawie C-183/05 Komisja przeciwko Irlandii, Zb. Orz. TE I-137, par. 17), uznał ten zarzut Komisji za zasadny ${ }^{99}$.

Trybunał odrzucił przy tym argumenty Republiki Austrii, że teren Hanság był chroniony w oparciu o dyrektywę siedliskową jako teren Natura 2000 oraz, że stan tego terenu nie uległ pogorszeniu. W tym zakresie Trybunał wskazał, że z jednej strony państwo członkowskie nie może bowiem uchylać się od zobowiqzań ciqżqcych na nim na mocy art. 4 ust. 1 i 2 dyrektywy ptasiej, powołujac się na przepisy inne niż ustanowione $w$ tej dyrektywie, poniewa $\dot{z}$ dyrektywy ptasia $i$ siedliskowa stanowiq dwa odrębne uregulowania prawne (wyrok z dnia 28 czerwca 2007 r. w sprawie C-235/04 Komisja przeciwko Hiszpanii, Zb. Orz. TE I-5415, par. 79). $Z$ drugiej strony okoliczność, $i \dot{z}$ stan danego terenu nie ulegt pogorszeniu, nie może podważać obowiqzku dokonania przez pań-

98 Sprawa C-535/07, par. 15.

99 Sprawa C-535/07, par. 19-22. 
stwa członkowskie klasyfikacji terenów jako OSO (zob. podobnie wyrok z dnia 13 grudnia 2007 r. w sprawie C-418/04 Komisja przeciwko Irlandii, Zb. Orz. TE I-10947, par. 38) ${ }^{100}$.

Przechodząc do analizy zarzutu nieprawidłowego wytyczenia granic OSO Niedere Tauern, w sytuacji zmniejszenia przed $2008 \mathrm{r}$. powierzchni tego terenu, a po upływie terminu wyznaczonego w uzasadnionej opinii zwiększenia tej powierzchni, Trybunał przyjął jako punkt wyjścia stan sprzed $2008 \mathrm{r}$. Wprowadzane przez władze Republiki Austriackiej zmiany co do powierzchni tego OSO, uzasadniane wymogiem zapewnienia odpowiedniej ochrony mornela - gatunku wymienionego w załączniku I do dyrektywy ptasiej, Trybunał potraktował jako dowodzące okoliczności, że w chwili upływu terminu wyznaczonego w uzasadnionej opinii powierzchnia omawianego OSO była niewystarczająca, jeżeli chodzi o wymogi ochrony określone w art. 4 ust. 1 dyrektywy ptasiej. W ocenie Trybunału było to równoznaczne $\mathrm{z}$ naruszenie tego przepisu dyrektywy ptasiej przez Republikę Austriacką ${ }^{101}$.

Rozpatrując drugi zarzut Komisji, dotyczący naruszenia art. 4 ust. 1 lub 2 dyrektywy ptasiej i art. 6 ust. 2 dyrektywy siedliskowej w związku z jej art. 7 ze względu na niewystarczającą ochronę prawną części już sklasyfikowanych OSO, Trybunał przypomniał swoje orzecznictwo na tle tych przepisów dyrektywy ptasiej. W odniesieniu do art. 4 ust. 1-2 tej dyrektywy Trybunał wskazał więc, że regulacje te wymagają od państw członkowskich przyznania OSO systemu ochrony prawnej, który pozwoli zapewnić w szczególności przetrwanie i wylęg gatunków ptactwa wymienionych $w$ załaczniku I, jak również wylęg, pierzenie i zimowanie regularnie występujących gatunków wędrownych niewymienionych $w$ załaczniku I (zob. wyrok z dnia 18 marca 1999 r. w sprawie C-166/97 Komisja przeciwko Francji, Zb. Orz. TE I-1719, par. 21; ww. wyrok z dnia 13 grudnia 2007 r. w sprawie Komisja przeciwko Irlandii, par. 153; wyrok z dnia 11 grudnia 2008 r. w sprawie C-293/07 Komisja przeciwko Grecji, par. 22). Ustalone jest również, że art. 4 dyrektywy ptasiej przewiduje wzmocniony sys-

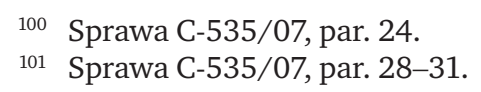


tem ochrony, nakierowany szczególnie tak na gatunki wymienione $w$ załaczniku I, jak i na gatunki wędrowne, co znajduje uzasadnienie $w$ fakcie, $i \dot{z}$ chodzi tu odpowiednio o gatunki najbardziej zagrożone i gatunki stanowiace wspólne dziedzictwo Unii Europejskiej (wyrok z dnia 11 lipca 1996 r. w sprawie C-44/95 Royal Society for the Protection of Birds, Zb. Orz. TE I-3805, par. 23; ww. wyroki: z dnia 13 grudnia 2007 r. w sprawie Komisja przeciwko Irlandii, par. 46; w sprawie Komisja przeciwko Grecji, par. 23) ${ }^{102}$.

Z kolei w odniesieniu do art. 6 ust. 2 dyrektywy ptasiej, Trybunał przypomniał, że obowiązi [tego przepisu] - jeżeli chodzi o obszary sklasyfikowane - zastępuja obowiqzki wynikajace z art. 4 ust. 4 zdanie pierwsze dyrektywy ptasiej, status ochrony prawnej OSO ma również zagwarantować uniknięcie na tych obszarach pogorszenia stanu siedlisk przyrodniczych i siedlisk gatunków, jak również uniknięcie istotnego niepokojenia gatunków, dla których zostaty one sklasyfikowane (zob. wyrok z dnia 27 lutego 2003 r. w sprawie C-415/01 Komisja przeciwko Belgii, Zb. Orz. TE I-2081, par. 16; ww. wyrok w sprawie Komisja przeciwko Grecji, par. 24). Ponadto ochrona OSO nie może ograniczać się do działań zmierzajacych do odpierania szkodliwego oddziaływania człowie$k a$, lecz musi $w$ zależności od sytuacji obejmować również dziatania pozytywne, majace na celu zachowanie lub polepszenie stanu danego terenu (zob. podobnie ww. wyrok z dnia 13 grudnia 2007 r. w sprawie Komisja przeciwko Irlandii, par. 154) ${ }^{103}$.

Trybunał wskazał, że z uwagi na charakter aktu, jakim jest dyrektywa, nie ulega wątpliwości, że Republika Austrii mogła by la wybrać formę i środki celem implementacji dyrektywy ptasiej do prawa krajowego. Trybunał zaznaczył przy tym, że dokładność transpozycji ma wprawdzie szczególne znaczenie w przypadku dyrektywy ptasiej, ponieważ powierza ona państwom członkowskim zarzqdzanie wspólnym dziedzictwem na ich terytoriach (zob. ww. wyrok z dnia 13 grudnia 2007 r. w sprawie Komisja przeciwko Irlandii, par. 64, 159), nie może ona $w$ każdym razie wymagać od państw członkowskich właczenia nakazów i zakazów wynikających z art. 4 ust. 1 i 2 dyrektywy ptasiej i art. 6 ust. 2 dyrektywy siedli-

102 Sprawa C-535/07, par. 56-57.

103 Sprawa C-535/07, par. 58-59. 
skowej do aktu prawnego, który ustala dla każdego OSO chronione gatunki i siedliska jako cele zachowawcze ${ }^{104}$.

Następnie Trybunał dodał, ¿̇e przyjęcie środków pozytywnych majacych na celu zachowanie i polepszenie stanu danego OSO nie ma charakteru systemowego, lecz zależy od konkretnej sytuacji danego OSO (zob. par. 34 wyroku z dnia 20 października 2005 r. w sprawie C-6/04 Komisja przeciwko Zjednoczonemu Królestwu, Zb. Orz. TE I-9017) ${ }^{105}$. W odniesieniu do postulowanych przez Komisję zakazów, które jej zdaniem powinny być specyficzne dla określonych OSO i gatunków, Trybunał uznał, że chociaż prawda jest, $\dot{z}$ e na przykład ochrona OSO przed działalnościa jednostek wymaga zapobiegania ich ewentualnie szkodliwej działalności (ww. wyrok z dnia 13 grudnia 2007 r. w sprawie Komisja przeciwko Irlandii, par. 208), realizacja tego celu nie wymaga jednak koniecznie wydania szczególnych zakazów dla każdego OSO, ani tėं - jak wynika z par. 20 wyroku z dnia 7 grudnia 2000 r. $w$ sprawie C-374/98 Komisja przeciwko Francji, Zb. Orz. TE I-10799 - dla każdego określonego gatunku ${ }^{106}$. Ponadto Trybunał dodał, że jeżeli chodzi o identyfikacje gatunków i siedlisk chronionych na każdym OSO, należy zaznaczyć, że tak jak wytyczenie granic OSO musi mieć niepodważalna forme wiażaca (zob. ww. wyrok $w$ sprawie Komisja przeciwko Belgii, par. 22), tak identyfikacja gatunków, które uzasadnity sklasyfikowanie tego OSO, musi odpowiadać temu samemu wymogowi. Gdyby bowiem tak nie było, zagrożone byłoby petne osiagnięcie celu ochrony wynikajacego z art. 4 ust. 1 i 2 dyrektywy ptasiej, jak $i$ art. 6 ust. 2 dyrektywy siedliskowej $w$ zwiqzku z jej art. 7. Jeżeli chodzi o cele zachowawcze, z par. 20 i 21 ww. wyroku z dnia 7 grudnia 2000 r. $w$ sprawie Komisja przeciwko Francji wynika, że status ochrony prawnej, z którego powinny korzystać OSO, nie oznacza, ̇̇e cele te musza być wyszczególnione dla każdego gatunku rozpatrywanego osobno. Poza tym, [...]nie można $w$ każdym razie uznać, że cele zachowawcze powinny być zawarte $w$ tym

106 Sprawa C-535/07, par. 63. 
samym akcie prawnym co akt, który dotyczy gatunków i siedlisk chronionych konkretnego OSO ${ }^{107}$.

Kontynuując swoje rozważania Trybunał stwierdził również, że jeżeli chodzi o rzekomo niewystarczajacy status ochrony prawnej OSO zwiazanych z rezerwatem przyrody lub innym rodzajem terenu sklasyfikowanego, które już istnieja i sq chronione środkami krajowymi lub regionalnymi, należy przypomnieć, ̇̇e [...] art. 4 dyrektywy ptasiej przewiduje wzmocniony system ochrony, nakierowany szczególnie tak na gatunki wymienione $w$ załaczniku I, jak i na gatunki wędrowne. Taka jest specyfika systemu ochrony, z którego powinny korzystać OSO, w przeciwieństwie do mniej ścistego ogólnego systemu ochrony przewidzianego $w$ art. 3 dyrektywy ptasiej dla wszystkich gatunków ptactwa przez niq objętych (zob. podobnie ww. wyrok $w$ sprawie Royal Society for the Protection of Birds, par. 19, 24). Nie oznacza to jednak, że tylko szczególnie określone uregulowanie wprowadzone dla każdego OSO mogłoby zapewnić skutecznq ochronę tego rodzaju terenu ${ }^{108}$.

Konkludując przedstawione wyżej oceny, Trybunał uznał ostatecznie, że Komisja nie zdołała wykazać, że miało miejsce ogólne uchybienie przez Republikę Austrii obowiązkom określonym w art. 4 ust. 1 lub 2 dyrektywy ptasiej i art. 6 ust. 2 dyrektywy siedliskowej w związku z jej art. 7. W jego ocenie, badanie istnienia uchybień polegać winno było na szczegółowej analizie regulacji pranych obowiązujących $\mathrm{w}$ poszczególnych krajach związkowych w chwili upływu terminu wyznaczonego w uzasadnionej opinii i w zakresie określonym przez Komisję w skardze (za wyjątkiem krajów związkowych Salzburg, Styria i Dolna Austria, gdyż w tej części Trybunał ocenił skargę Komisji jako niedopuszczalną) $)^{109}$. Po przeprowadzeniu szczegółowych analiz w tym zakresie, Trybunał ostatecznie stwierdził, że Republika Austrii nie przyznała ochrony prawnej zgodnej z wymogami art. 4 dyrektywy ptasiej i art. 6 ust. 2 dyrektywy siedliskowej w związku z jej art. 7 (uchybiając w ten sposób zobowiązaniom ciążącym na niej na mocy tych przepisów), następującym OSO

107 Sprawa C-535/07, par. 64-65.

108 Sprawa C-535/07, par. 66.

109 Sprawa C-535/07, par. 67-68. 
znajdującym się wśród zgłoszonych w skardze przez Komisję: Maltsch, Wiesengebiete im Freiwald, Pfeifer Anger, Oberes Donautal i Untere Traun w kraju związkowym Górna Austria, jak również OSO Verwall w kraju związkowym Vorarlberg ${ }^{110}$.

\section{VIII.3. WYROK TRYBUNAŁU Z DNIA 11 LISTOPADA 2010 R. W SPRAWIE C-164/09 KOMISJA EUROPEJSKA PRZECIWKO REPUBLICE WŁOSKIEJ ${ }^{111}$}

Przedmiot: uchybienie zobowiązaniom państwa członkowskiego - naruszenie art. 9 dyrektywy Rady 79/409/EWG z dnia 2 kwietnia 1979 r. w sprawie ochrony dzikiego ptactwa - odstępstwa od systemu ochrony dzikiego ptactwa - Region Veneto.

Sentencja:

1) Ponieważ Region Veneto ustanowił i stosował przepisy zezwalające na odstępstwa od systemu ochrony dzikiego ptactwa, które nie spełniają przesłanek określonych w art. 9 dyrektywy Rady 79/409/EWG z dnia 2 kwietnia 1979 r. w sprawie ochrony dzikiego ptactwa, Republika Włoska uchybiła zobowiązaniom, które na niej ciążą na mocy art. 9 tej dyrektywy.

2) Republika Włoska zostaje obciążona kosztami postępowania.

\section{VIII.4. WYROK TRYBUNAEU Z DNIA 3 MARCA 2011 R. W SPRAWIE C-508/09 KOMISJA EUROPEJSKA PRZECIWKO REPUBLICE WŁOSKIEJ ${ }^{112}$}

Przedmiot: uchybienie zobowiązaniom państwa członkowskiego - naruszenie art. 9 dyrektywy Rady 79/409/EWG z dnia

110 Sprawa C-535/07, par. 115.

111 Dz. Urz. UE C 013 z 15.01.2011, s. 9-10; uzasadnienie wyroku dostępne jedynie we włoskiej i francuskiej wersji językowej.

112 Dz. Urz. C 130 z 30.04.2011, s. 7; uzasadnienie wyroku dostępne jedynie 3/2011 we włoskiej i francuskiej wersji językowej. 
2 kwietnia 1979 r. w sprawie ochrony dzikiego ptactwa - odstępstwa - Region Sardynii.

Sentencja:

1) Ze względu na to, że Region Sardynii przyjął i stosuje uregulowanie dotyczące zatwierdzania odstępstw od systemu ochrony dzikiego ptactwa, które narusza warunki określone w art. 9 dyrektywy Rady 79/409/EWG z dnia 2 kwietnia 1979 r. w sprawie ochrony dzikiego ptactwa, Republika Włoska uchybiła zobowiązaniom wynikającym z art. 9 tej dyrektywy.

2) Republika Włoska zostaje obciążona kosztami postępowania.

\section{VIII.5. WYROK TRYBUNAŁU Z DNIA 26 MAJA 2011 R. W SPRAWIE C-538/09 KOMISJA EUROPEJSKA PRZECIWKO KRÓLESTWU BELGII ${ }^{113}$}

1) Królestwo Belgii uchybiło zobowiązaniom, które na nim ciążą na mocy art. 6 ust. 3 dyrektywy Rady 92/43/EWG z dnia 21 maja 1992 r. w sprawie ochrony siedlisk przyrodniczych oraz dzikiej fauny i flory, nie wprowadzając w odniesieniu do pewnych rodzajów działalności podlegających systemowi zgłoszenia wymogu odpowiedniego badania dotyczącego oddziaływania na środowisko naturalne, gdy owe rodzaje działalności mogą mieć wpływ na teren Natura 2000.

2) Królestwo Belgii zostaje obciążone kosztami postępowania.

W sprawie C-538/09 Komisja otrzymała sygnał w 2006 r. dotyczący nieprawidłowości przy użytkowaniu obory o charakterze przemysłowym położonej na obszarze gminy Philippeville $\mathrm{w}$ regionie Walonii (Belgia) na skraju terenu Natura 2000 nazwanego „Bassin de Fagnard de l'Eau blanche en aval de Mariembourg”, który został wyznaczony jako specjalny obszar

113 http://curia.eu; dalej cyt.: sprawa C-538/09. 
ochrony. Podmiot zgłaszający te nieprawidłowości podkreślał, że znajdujący się w tym miejscu teren Natura 2000 doznał znacznego uszczerbku, który został spowodowany przez ścieki pochodzące ze wspomnianej obory, zagrażające wielu gatunkom wymienionym w załączniku do dyrektywy Rady 79/409/EWG z dnia 2 kwietnia 1979 r. w sprawie ochrony dzikiego ptactwa i w załączniku do dyrektywy siedliskowej ${ }^{114}$.

Na skutek tego zgłoszenia Komisja wszczęła postępowanie i zwróciła się do Królestwa Belgii o ustosunkowanie się do tych kwestii, a następnie po wymianie pism przedstawiła temu państwu członkowskiemu umotywowaną opinię. W odpowiedzi w 2008 r. władze belgijskie zapewniły Komisję, że to gospodarstwo rolne zostało już wyposażone w oczyszczalnię ścieków i nie dochodziło w późniejszym czasie do żadnych emisji na wspomniany teren Natura $2000^{115}$. Komisje jednakże, po ustaleniu, że $\mathrm{w}$ jej ocenie przepisy regionu Walonia mające znaczenie dla tego problemu nie zapewniały, że ocena oddziaływania na teren chroniony, wymagana w art. 6 ust. 3 dyrektywy siedliskowej, miała mieć charakter systematyczny, wniosła skargę do Trybunału ${ }^{116}$. W szczególności Komisja zarzuciła Królestwu Belgii, że państwo to naruszyło prawo unijne poprzez niewprowadzenie w odniesieniu do pewnych rodzajów działalności wymogu odpowiedniego badania dotyczącego oddziaływania na środowisko, w sytuacji gdy te rodzaje działalności mogły mieć wpływ na tereny Natura 2000, oraz poprzez poddanie pewnych rodzajów działalności systemowi zgłoszenia ${ }^{117}$.

Przystępując do oceny argumentów stron przedstawionych w sprawie C-538/09 Trybunał przypomniał, że art. 6 ust. 3 dyrektywy siedliskowej uzależnia wymóg dokonania odpowiedniej oceny skutków planu lub przedsięwzięcia od przestanki, że istnieje prawdopodobieństwo lub ryzyko, iż ów plan lub owo przedsięwzięcie będq oddziatywaty na dany teren $w$ istotny sposób. Z uwagi w szczególności na zasadę ostrożności ryzyko takie istnieje, gdy

114 Sprawa C-538/09, par. 14-15.

115 Sprawa C-538/09, par. 19.

116 Sprawa C-538/09, par. 21.

117 Sprawa C-538/09, par. 1. 
na podstawie obiektywnych danych nie można wykluczyć, że plan lub przedsięwzięcie będa oddziaływać na dany teren $w$ istotny sposób (zob. wyroki: z dnia 7 września 2004 r. w sprawie C-127/02 Waddenvereniging i Vogelbeschermingsvereniging, $Z b$. Orz. TE I-7405, par. 43, 44; z dnia 20 października 2005 r. w sprawie C-6/04 Komisja przeciwko Zjednoczonemu Królestwu, Zb. Or\%. TE I-9017, par. 54; z dnia 13 grudnia 2007 r. w sprawie C-418/04 Komisja przeciwko Irlandii, Zb. Orz. TE I-10947, par. 226) ${ }^{118}$. Oceny tego ryzyka należy dokonać $w$ szczególności w świetle charakterystycznych cech i specyficznych uwarunkowań środowiskowych terenu, którego dany plan lub dane przedsięwzięcie dotyczy (zob. ww. wyrok $w$ sprawie Waddenvereniging i Vogelbeschermingsvereni-

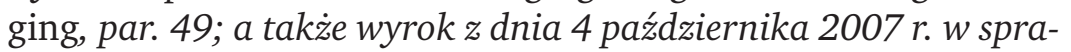
wie C-179/06 Komisja przeciwko Włochom, Zb. Orz. TE I-8131, par. 35). Ponadto przestanka, od której uzależniona jest ocena oddziatywania planu lub przedsięwzięcia na dany teren i która $w$ razie watpliwości dotyczacych braku istotnych skutków pociaga za sobq konieczność przeprowadzenia takiej oceny, nie pozwala na odstapienie od niej w przypadku pewnych kategorii przedsięwzięć na podstawie kryteriów, które nie gwarantujq, że owe przedsięwzięcia nie będa mogty oddziatywać $w$ istotny sposób na tereny chronione (zob. podobnie wyrok z dnia 10 stycznia 2006 r. w sprawie C-98/03 Komisja przeciwko Niemcom, Zb. Orz. TE I-53, par. 41). Możliwość ogólnego zwolnienia pewnych rodzajów działalności na podstawie obowiqzujących przepisów z obowiq̨zku dokonania oceny oddziabywania na dany teren nie może bowiem zagwarantować, że te rodzaje działalności nie będq miały niekorzystnego wptywu na teren chroniony (zob. podobnie ww. wyrok $w$ sprawie Komisja przeciwko Niemcom, par. 43, 44; wyrok z dnia 4 marca 2010 r. $w$ sprawie C-241/08 Komisja przeciwko Francji, Zb. Orz. TE [2010] I-01697, par. 31$)^{119}$.

Kontynuując omawianie utrwalonej linii orzeczniczej w tym przedmiocie, Trybunał skonkludował, że art. 6 ust. $3 d y-$ rektywy siedliskowej nie zezwala państwu członkowskiemu na wydanie przepisów krajowych, które zwalniałyby w sposób ogólny

118 Sprawa C-538/09, par. 39.

119 Sprawa C-538/09, par. 40-42. 
przedsięwzięcia inwestycyjne z obowiazku dokonania oceny oddziatywania na teren z uwagi na niewielkq kwote planowanych wydatków lub na specyficzne dziedziny działalności (zob. wyrok z dnia 6 kwietnia 2000 r. w sprawie C-256/98 Komisja przeciwko Francji, Zb. Orz. TE I-2487, pkt 39) ${ }^{120}$. Podobnie, zwalniajac systematycznie z procedury oceny oddziatywania na teren programy i projekty prac, robót lub przedsięwzięcia inwestycyjne podlegajace systemowi zgłoszenia, państwo członkowskie uchybia zobowiązaniom, które ciqżq na nim na mocy art. 6 ust. 3 dyrektywy siedliskowej (zob. podobnie ww. wyrok z dnia 4 marca 2010 r. w sprawie Komisja przeciwko Francji, par. 62) ${ }^{121}$. Z orzecznictwa Trybunału wynika więc, że zgodnie z art. 6 ust. 3 dyrektywy siedliskowej państwo członkowskie nie może zasadniczo zwolnić w sposób systematyczny i ogólny pewnych kategorii planów lub przedsięwzięć z obowiazku dokonania oceny ich wptywu na tereny Natura 2000 ze względu na rodzaj działalności lub poprzez wprowadzenie systemu zgłoszenia ${ }^{122}$.

W świetle przytoczonego powyżej orzecznictwa Trybunał podjął analizę przepisów belgijskich (w odniesieniu do regionu Walonia) dotyczących oceny oddziaływania na środowisko określonych planów lub przedsięwzięć, jak i wprowadzonego systemu zwolnień niektórych planów lub przedsięwzięć od obowiązku uzyskania pozwolenia, a tym samym od przeprowadzenia oceny oddziaływania na środowisko na teren Natura 2000. Analiza ta prowadziła, zdaniem Trybunału, do wniosku, że takie rozwiązania prawne zostały rzeczywiści przyjęte ${ }^{123}$. Na tym tle Trybunał zaznaczył, że jeśli państwo członkowskie wprowadza system zgłoszenia, który nie przewiduje oceny ryzyka w szczególności $w$ świetle charakterystycznych cech $i$ specyficznych uwarunkowań środowiskowych danego terenu, owo państwo członkowskie powinno wykazać, $i \dot{z}$ wydane przez nie przepisy pozwalaja wykluczyć na podstawie obiektywnych danych, $\dot{z} e ~ k a \dot{d} d y$ plan lub każde przedsięwzięcie, podlegajace wspomnianemu systemowi zgłoszenia, będa oddziatywać $w$ znaczacym stopniu na teren Natura 2000, oddziel-

120 Sprawa C-538/09, par. 43.

121 Sprawa C-538/09, par. 44.

122 Sprawa C-538/09, par. 45.

123 Sprawa C-538/09, par. 51. 
nie lub wspólnie z innymi planami lub przedsięwzięciami (zob. podobnie $i$ analogicznie ww. wyrok z dnia 4 marca 2010 r. $w$ sprawie Komisja przeciwko Francji, par. 32) ${ }^{124} . Z$ art. 6 ust. 3 dyrektywy siedliskowej można bowiem wyprowadzić wniosek, że wtaściwe władze krajowe mogq zwolnić się z obowiazku dokonania oceny oddziatywania planu lub przedsięwzięcia, które nie sq bezpośrednio zwiazane z zagospodarowaniem terenu Natura 2000 lub konieczne do jego zagospodarowania wyłacznie, jeżeli na podstawie obiektywnych danych można wykluczyć, że ów plan lub owo przedsięwzięcie będa oddziaływać w znaczqcym stopniu na rzeczony teren, oddzielnie lub wspólnie z innymi planami lub przedsięwzięciami (zob. podobnie ww. wyroki: $w$ sprawie Waddenvereniging i Vogelbeschermingsvereniging, par. 45; a także $w$ sprawie Komisja przeciwko Irlandii, par. 238) ${ }^{125}$.

Stojąc na tym stanowisku Trybunał odrzucił argument władz belgijskich co do tego, że system zgłoszenia dotyczył wyłącznie urządzeń i rodzajów działalności mających niewielki wpływ na człowieka i środowisko naturalne, w odniesieniu do których rząd określił warunki całościowe. W odniesieniu do tej kwestii Trybunał podkreślił, że nawet przedsięwzięcie na niewielkq skalę może oddziaływać $w$ istotny sposób na środowisko naturalne, jeżeli owo przedsięwzięcie jest zlokalizowane $w$ miejscu, $w$ którym czynniki środowiskowe takie jak fauna i flora, gleba, woda, klimat lub dziedzictwo kulturowe sq czute na najmniejszq zmiane (zob. podobnie, jeśli chodzi o dyrektywę 85/337, wyrok z dnia 21 września 1999 r. $w$ sprawie C-392/96 Komisja przeciwko Irlandii, Zb. Orz. TE I-5901, par. 66). Państwo członkowskie nie może więc przyjąć za pewnik tego, że kategorie planów lub przedsięwzięć, określone według rodzajów działalności i specyficznych urzadzeń, będa z definicji wywierać niewielki wpływ na człowieka i na środowisko naturalne ${ }^{126}$.

W dalszej kolejności Trybunał nie uwzględnił też tłumaczeń władz belgijskich, które wskazywały że opracowując listę rodzajów działalności lub urządzeń celem m.in. wprowadzenia sys-

24 Sprawa C-538/09, par. 52.

125 Sprawa C-538/09, par. 53.

126 Sprawa C-538/09, par. 55-56. 
temu zwolnień zleciły analizę rodzajów działalności mogących wywierać wpływ na środowisko naturalne, z uwzględnieniem kryteriów określonych w załączniku III do dyrektywy 85/337. Analiza ta nie została jednakże przedłożona Trybunałowi ${ }^{127}$.

Podobnie rzecz się przedstawiała w przypadku twierdzeń władz belgijskich co do tego, że zgodnie z przepisami krajowymi w sytuacji, gdy zakład kwalifikujący się wstępnie do zwolnienia nie mógł spełnić tzw. całościowych kryteriów koniecznych do uzyskania tego zwolnienia, to podlegał ogólnemu obowiązkowi dokonania oceny oddziaływania planowanego zakładu na dany teren Natura 2000 (nakładanemu w drodze decyzji organu środowiskowego). Ze względu jednak na to, że Królestwo Belgii nie przedstawiło Trybunałowi tych regulacji prawnych, ani nie zdołało wyjaśnić, w jaki konkretnie sposób przepisy te miały zaradzić brakowi odpowiedniej oceny oddziaływania planów lub przedsięwzięć, mogących wpłynąć $\mathrm{w}$ istotny sposób na teren chroniony, Trybunał nie uznał tych wyjaśnieńn ${ }^{128}$. Ponadto, Trybunał ocenił, że Królestwo Belgii nie uzasadniło wystarczająco swych twierdzeń co do tego, że ogólne przepisy, takie jak belgijska ustawa o ochronie przyrody, czy też belgijski kodeks ochrony środowiska, ogólnie zapewniały skuteczną ochronę terenów Natura 2000 w regionie Walonii ${ }^{129}$. W konsekwencji Trybunał uznał, że skarga Komisji była zasadna, gdyż Królestwo Belgii uchybiło zobowiqzaniom, które na nim ciażq na mocy art. 6 ust. 3 dyrektywy siedliskowej, nie wprowadzajac $w$ odniesieniu do pewnych rodzajów działalności podlegających systemowi zgłoszenia wymogu odpowiedniego badania dotyczqcego oddziatywania na środowisko naturalne, gdy owe rodzaje działalności mogq mieć wptyw na teren Natura $2000^{130}$.

127 Sprawa C-538/09, par. 57-58.

128 Sprawa C-538/09, par. 59-60.

130 Sprawa C-538/09, par. 66. 


\section{VIII.6. WYROK TRYBUNAŁU Z DNIA 9 CZERWCA 2011 R. W SPRAWIE C-383/09 KOMISJA EUROPEJSKA PRZECIWKO REPUBLICE FRANCUSKIEJ ${ }^{131}$}

1) Nie ustanawiając programu środków umożliwiających ścisłą ochronę gatunku Cricetus cricetus (chomik europejski), Republika Francuska uchybiła zobowiązaniom ciążącym na niej na mocy art. 12 ust. 1 lit. d) dyrektywy Rady 92/43/EWG z dnia 21 maja 1992 r. w sprawie ochrony siedlisk przyrodniczych oraz dzikiej fauny i flory po zmianach wprowadzonych dyrektywą Rady 2006/105/WE z dnia 20 listopada 2006 r.

2) Republika Francuska zostaje obciążona kosztami postępowania.

W sprawie C-383/09 Komisja zarzuciła Republice Francuskiej naruszenie dyrektywy siedliskowej, polegające na nie przyjęciu programu środków umożliwiających ścisłą ochronę gatunku Cricetus cricetus (chomik europejski). Komisja otrzymała sygnały o niewłaściwym stanie ochrony chomika europejskiego w Alzacji, o czym poinformowała władze francuskie na początku 2007 r. Na skutek tego działania Komisji do czerwca 2008 r. trwała wymiana pism między nią a Republiką Francuską. Ostatecznie Komisja w uzasadnionej opinii zarzuciła temu państwu członkowskiemu uchybienie zobowiązaniom z art. 12 ust. 1 lit. d) dyrektywy siedliskowej na skutek braku programu środków umożliwiających ścisłą ochronę chomika europejskiego. Republika Francuska poinformowała wprawdzie Komisję o zatrzymaniu się w 2008 r. na części terytorium alzackiego zaobserwowano tendencji spadkowej liczebności tego gatunku oraz o stadium zaawansowania środków wprowadzonych w ramach planu działania mającego na celu ochronę tego gatunku w latach 2007-2011, jednakże Komisja zdecydowała o wniesieniu skargi ${ }^{132}$.

Przystępując do oceny argumentów stron przedstawionych w sprawie C-383/09, Trybunał przypomniał, że art. 12 ust. 1

131 http://curia.eu; dalej cyt.: sprawa C-383/09.

132 Sprawa C-383/09, par. 7. 10-13. 
lit. d) dyrektywy siedliskowej nakłada na państwa członkowskie obowiqzek podjęcia koniecznych środków majacych na celu ustanowienie systemu ścisłej ochrony gatunków zwierzq̨ wymienionych $w$ załaczniku IV lit. a) tej dyrektywy $w$ ich naturalnym zasięgu, zakazujacych pogarszania stanu lub niszczenia terenów rozrodu lub odpoczynku. Dokonanie transpozycji tego przepisu nakłada na państwa członkowskie nie tylko obowiazek ustanowienia kompletnych ram legislacyjnych, ale również podjęcia konkretnych i szczególnych działań $w$ zakresie ochrony (zob. podobnie wyrok z dnia 11 stycznia 2007 r. $w$ sprawie C-183/05 Komisja przeciwko Irlandii, Zb. Orz. TE I-137, par. 29). Tym samym system ścisłej ochrony zakłada podjęcie spójnych i wzajemnie powiązanych działań o charakterze prewencyjnym (wyrok z dnia 16 marca 2006 r. w sprawie C-518/04 Komisja przeciwko Grecji, Zb. Orz. TE I-42, par. 16; ww. wyrok $w$ sprawie Komisja przeciwko Irlandii, par. 30) ${ }^{133}$. W ocenie Trybunał tego rodzaju system ścistej ochrony winien więc umożliwiać skuteczne powstrzymywanie procesów pogarszania stanu lub niszczenia terenów rozrodu lub odpoczynku gatunków zwierzqt wymienionych $w$ załaczniku IV lit. a) dyrektywy siedliskowej (zob. podobnie wyrok z dnia 30 stycznia 2002 r. w sprawie C-103/00 Komisja przeciwko Grecji, Zb. Or\%. TE I-1147, par. 39) ${ }^{134}$.

Przyjmując dzień 5 sierpnia 2008 r., czyli datę upływu terminu z uzasadnionej opinii Komisji, Trybunał ocenił, że $w$ latach 2001-2007 liczba nor chomika europejskiego na stużacym za punkt odniesienia dla obserwacji populacji tego gatunku głównym obszarze jego występowania zmniejszyła się z ponad 1160 do mniej niż 180 sztuk. Ponadto ze sporzqdzonych przez Office National de la Chasse et de la Faune Sauvage (krajowy instytut łowiectwa $i$ zwierzyny) i niezakwestionowanych przez Republikę Francuska obliczeń liczebności tego gatunku w 2009 r. wynika, że żadna zjego populacji nie osiaga $w$ Alzacji minimalnego progu dla zdolnej do przė̇ycia populacji tego gatunku, która powinna liczyć 1500 osobników rozmieszczonych na korzystnym pod względem wykorzystania gruntów obszarze 600 ha należącym do jednego właściciela. $W$ skierowanym przez sekretarza stanu ds. ekologii do prefekta

134 Sprawa C-383/09, par. 21. 
regionu Alzacji piśmie z dnia 28 sierpnia 2009 r. [...]wskazano, $\dot{z}$ e,pomimo zastosowania środków przedstawionych $w$ planie odtworzenia [populacji chomika europejskiego] (2007-2011) oraz podjętych przez zainteresowane strony odpowiednich zobowiazań majacych na celu zachowanie tego gatunku, otrzymane na dzień dzisiejszy wyniki badań biologicznych sq niewystarczajace do tego, aby gatunek ten zostat zachowany we Francji”, i że wobec tego „konieczna jest szybka i znaczqca poprawa treści przepisów dotyczacych chomika europejskiego $w$ taki sposób, aby uzyskać w krótkim okresie wyniki świadczqce o odtwarzaniu się tego gatunku”. Republika Francuska przyznaje, ̇̇e następujący kosztem bioróżnorodności rozwój uprawy kukurydzy wywarł negatywny wptyw na chomika europejskiego, który jest uzależniony od łąk uprawnych, zwłaszcza tych obsadzonych lucerna; rozwój uprawy kukurydzy stanowi jeden z istotnych czynników, które spowodowaty spadek liczebności populacji tego gatunku. Nie ulega watpliwości co do tego, że nawet $w$ ciagu ostatnich lat rozwój ten nie został catkowicie zahamowany $w$ Alzacji, która jest jedynym francuskim regionem, $w$ której gatunek ten jeszcze występuje ${ }^{135}$.

Następnie Trybunał ocenił, że z akt sprawy wynikało, iż Republika Francuska sama przyznała w części swych pism i poprzez niektóre swoje działania (zwłaszcza jeśli chodzi o okoliczności utworzenia tzw. priorytetowych stref działania - zones d'action prioritaire-ZAP, oraz tzw. obszaru ponownego zasiedlenia), że stan ochrony tego gatunku na terenie Alzacji był niewystarczający w chwili upływu terminu z umotywowanej opinii. W szczególności środki te okazały się nieskuteczne jeśli chodzi o powstrzymanie procesu pogarszania stanu lub niszczenia terenów rozrodu lub odpoczynku chomika europejskiego ${ }^{136}$. Mając powyższe na względzie Trybunał stwierdził więc, że nie ustanawiając programu środków umożliwiających ścisłą ochronę gatunku Cricetus cricetus (chomik europejski), Republika Francuska uchybiła zobowiązaniom ciążącym na niej na mocy art. 12 ust. 1 lit. d) dyrektywy siedliskowej ${ }^{137}$.

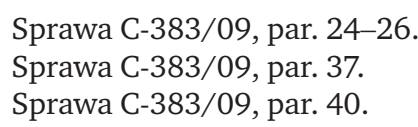


VIII.7. WYROK TRYBUNAŁU Z DNIA 21 LIPCA 2011 R.

\section{W SPRAWIE C-2/10 AZIENDA AGRO-ZOOTECNICA FRANCHINI SARL I EOLICA DI ALTAMURA SRL PRZECIWKO REGIONE PUGLIA ${ }^{138}$}

Dyrektywę Rady 92/43/EWG z dnia 21 maja 1992 r. w sprawie ochrony siedlisk przyrodniczych oraz dzikiej fauny i flory oraz dyrektywę Rady 79/409/WE z dnia 2 kwietnia 1979 r. w sprawie ochrony dzikiego ptactwa, dyrektywę 2001/77/WE Parlamentu Europejskiego i Rady z dnia 27 września 2001 r. w sprawie wspierania produkcji na rynku wewnętrznym energii elektrycznej wytwarzanej ze źródeł odnawialnych ${ }^{139}$ i dyrektywę Parlamentu Europejskiego i Rady 2009/28/WE z dnia 23 kwietnia 2009 r. w sprawie promowania stosowania energii ze źródeł odnawialnych zmieniającą i w następstwie uchylającą dyrektywy 2001/77/WE oraz 2003/30/WE ${ }^{140}$ należy interpretować w ten sposób, że nie stoją one na przeszkodzie istnieniu uregulowań, które zakazują lokalizacji turbin wiatrowych nieprzeznaczonych do własnego użytku na obszarach należących do sieci Natura 2000 bez jakiejkolwiek uprzedniej oceny skutków przedsięwzięcia dla środowiska na obszarze, na którym ma być ono realizowane, o ile przestrzegane są zasady niedyskryminacji i proporcjonalności.

Z pytaniami prejudycjalnymi w sprawie C-2/10 zwrócił się do Trybunału włoski sąd krajowy - Tribunale amministrativo regionale per la Puglia, na tle sporu między Azienda Agro-Zootecnica Franchini Sarl i Eolica di Altamura Srl a Regione Puglia (regionem Apulia) dotyczącego odmowy pozwolenia na lokalizację turbin nieprzeznaczonych do własnego użytku na terenie znajdującym się wewnątrz parku narodowego Alta Murgia. Ten park narodowy jest obszarem chronionym zaklasyfikowanym jako obszar mający znaczenie dla Wspólnoty (zwany dalej „OZW”) oraz jako obszar specjalnej ochrony (zwany dalej „OSO”), sta-

\footnotetext{
138 http://curia.eu; dalej cyt.: sprawa C-2/10.

139 Dz. Urz. UE L 283 z 27.10.2001, s. 33-40 ze zm.

140 Dz. Urz. UE L 140 z 5.6.2009, s. 16-62.
} 
nowiącym część europejskiej sieci ekologicznej Natura 2000 (zwanej dalej „siecią Natura 2000”). Odmowa miała miejsce ze względu na fakt, że planowana inwestycja nie została uprzednio objęta oceną skutków dla środowiska przedsięwzięcia na teren, na którym projekt ma być realizowany ${ }^{141}$. Władze regionu Apulia w szczególności uzasadniały odmowę udzielenia pozwolenia tym, że w świetle przepisów krajowych lokalizacja turbin wiatrowych nie mogła mieć miejsce na terenach uznanych za całkowicie „niewłaściwe” dla tych celów, za które to tereny zostały również uznane obszary OZW i OSO wyznaczone na podstawie dyrektywy siedliskowej i dyrektywy ptasiej ${ }^{142}$.

Odmowa ta została zaskarżone przez obie spółki. W trakcie postępowania instancyjnego zmienił się stan prawny mający znaczenie dla sprawy, to znaczy weszła w życie ustawa regionalna nr 31. W art. 2 ust. 6 tej ustawy wprowadzono zakaz budowy nowych turbin wiatrowych nieprzeznaczonych do własnego użytku na wszystkich obszarach sieci Natura 2000, tzn. również na obszarach o znaczeniu dla Wspólnoty wyznaczonych zgodnie z dyrektywą siedliskową. Sąd włoski wskazał, że w jego ocenie tenże art. 2 ust. 6 ustawy regionalnej nr 31 znajdował bezpośrednie zastosowanie do projektu farmy wiatrowej przedstawionego przez spółki Azienda Agro-Zootecnica Franchini i Eolica di Altamura. Przepis ten bowiem miał zastosowanie do wniosku o wydanie pozwolenia i stwierdzenie zgodności z ochroną środowiska podtrzymywanego przez te spółki od dnia wejścia w życie ustawy regionalnej nr 31 (to znaczy od dnia 8 listopada 2008 r.), niezależnie od jakiejkolwiek szczególnej oceny wpływu na środowisku lub skutków dla środowiska ${ }^{143}$.

W tych okolicznościach włoski sąd krajowy uznał, że istniała potrzeba zwrócenia się do Trybunału w trybie pytań prejudycjalnych. Zagadnienie prawne przedstawione przez ten sąd zostało niewłaściwie sformułowane, to jest było to zapytanie o przepisy prawa krajowego, zamiast o wykładnię prawa unijnego. Trybunał przyjął jednakże sprawę, po wstępnym prze-

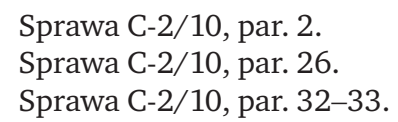


formułowaniu zapytania sądu włoskiego. Trybunał uznał więc, że włoski sąd krajowy zwrócił się o wyjaśnienie, czy dyrektywa siedliskowa i dyrektywa ptasia, dyrektywy 2001/77 i 2009/28, powinny być interpretowane $w$ ten sposób, że sprzeciwiaja się one uregulowaniom, które zakazują lokalizacji turbin wiatrowych nieprzeznaczonych do wtasnego użytku na obszarach należacych do sieci Natura 2000, bez jakiejkolwiek uprzedniej oceny skutków dla środowiska przedsięwzięcia na obszarze, na którym ma ono zostać zrealizowane ${ }^{144}$. Analizę w tym zakresie Trybunał przeprowadził dwutorowo - w pierwszej kolejności zajął się wykładnią przepisów dyrektywy siedliskowej i dyrektywy ptasiej, a następnie przeszedł do oceny rozważanego zagadnienia w świetle dyrektyw 2001/77 i 2009/28.

W odniesieniu do wykładni dyrektywy siedliskowej i dyrektywy ptasiej Trybunał na wstępie przypomniał, że system ochrony, który dyrektywa siedliskowa i dyrektywa ptasia przyznajq obszarom należacym do sieci Natura 2000, nie zakazuje prowadzenia jakiejkolwiek działalności ludzkiej w obrębie tych obszarów, lecz uzależnia jedynie udzielenie pozwolenia na tę działalność od przeprowadzenia uprzedniej oceny skutków wywieranych przez dane przedsięwzięcia na środowisko naturalne. Zgodnie zatem z art. 6 ust. 3 zdanie pierwsze dyrektywy siedliskowej - majacym zastosowanie na podstawie art. 7 tej dyrektywy do obszarów sklasyfikowanych zgodnie z art. 4 ust. 1 dyrektywy ptasiej lub zakwalifikowanych $w$ podobny sposób na mocy jej art. 4 ust. 2 - każdy plan lub każde przedsięwzięcie, które nie sq bezpośrednio zwiqzane lub konieczne do zagospodarowania terenu, ale które moga $w$ istotny sposób na ten teren oddziaływać, zarówno oddzielnie, jak i $w$ połączeniu z innymi planami lub przedsięwzięciami, podlegaja ocenie ich skutków dla danego terenu z punktu widzenia założeń jego ochrony. Ponadto zgodnie z utrwalonym orzecznictwem uruchomienie mechanizmu ochrony środowiska przewidzianego $w$ art. 6 ust. 3 dyrektywy siedliskowej zakłada zaistnienie prawdopodobieństwa lub ryzyka, że plan lub przedsięwzięcie może oddziatywać na dany teren $w$ istotny sposób (zob. w szczególności wyroki: 
z dnia 7 września 2004 r. w sprawie C-127/02 Waddenvereniging i Vogelbeschermingsvereniging, Zb. Orz. TE I-7405, par. 40, 43; a także z dnia 4 października 2007 r. w sprawie C-179/06 Komisja przeciwko Włochom, Zb. Orz. TE I-8131, par. 33). W rezultacie wydaje się, że ustawodawca Unii zamierzat stworzyć mechanizm ochrony, który zostaje uruchomiony jedynie w sytuacji, gdy plan lub przedsięwzięcie stwarza zagrożenie dla obszaru należacego do sieci Natura $2000^{145}$.

Trybunał uznał, że w świetle powyższych ustaleń należy przeprowadzić ocenę stanu faktycznego w sprawie zawisłej przed sądem krajowym. Trybunał stwierdził, że w Republice Włoskiej ustanowiony został zakaz budowy nowych turbin wiatrowych nieprzeznaczonych do własnego użytku na OZW i OSO należących do sieci Natura 2000, rozciągający się na 200 m w obszarze buforowym. Wprowadzenie tego zakazu skutkowało koniecznością odmowy wydania pozwolenia na jakikolwiek plan lub przedsięwzięcie zmierzające do umieszczenia nowej turbiny wiatrowej na jednym z tych obszarów i to bez dokonania jakiejkolwiek oceny skutków określonego planu lub przedsięwzięcia dla środowiska na konkretnym obszarze. W ocenie Trybunału to rozwiązanie przyjęte przez prawodawcę włoskiego winno być zakwalifikowane jako ustanowienie bardziej restrykcyjnego systemu ochrony obszarów należących do sieci Natura 2000 od systemu wprowadzonego zgodnie z dyrektywą siedliskową i dyrektywą ptasią ${ }^{146}$.

Następnie Trybunał przeprowadził analizę odnośnie tego, czy ustanowienie przez państwo członkowskie takiego bardziej rygorystycznego systemu ochrony jest zgodne z prawem unijnym. Zdaniem Trybunału zarówno art. 14 dyrektywy ptasiej (w myśl którego państwa członkowskie mogą wprowadzać bardziej rygorystyczne środki ochronne niż przewidziane $\mathrm{w}$ tej dyrektywie), jak i art. 193 TFUE w związku z dyrektywą siedliskową, umożliwiają państwom członkowskim wydanie bardziej rygorystycznych środków ochronnych, przy braku całkowitej harmonizacji przepisów Unii w dziedzinie ochrony środowiska

145 Sprawa C-2/10, par. 40-42.

146 Sprawa C-2/10, par. 44-46. 
(zob. w szczególności wyroki: z dnia 22 czerwca 2000 r. w sprawie C-318/98 Fornasar i in., Z. Orz. TE I-4785, par. 46; a także z dnia 14 kwietnia 2005 r. w sprawie C-6/03 Deponiezweckverband Eiterköpfe, Zb. Orz. TE I-2753, par. 27) ${ }^{147}$.

W dalszej kolejności Trybunał stwierdził, że uregulowania krajowe i regionalne będace przedmiotem postępowania przed sqdem krajowym majq zasadniczo na celu zachowanie obszarów należących do sieci Natura 2000, w szczególności ochronę siedlisk dzikiego ptactwa przed zagrożeniami, jakie moga stanowić dla nich turbiny wiatrowe. Z powyższego wynika, że uregulowania takie jak będace przedmiotem postępowania przed sadem krajowym, które $w$ celu zapewnienia ochrony populacji dzikiego ptactwa zamieszkujacego obszary chronione należace do sieci Natura 2000 zakazuja w sposób bezwzględny budowy nowych turbin wiatrowych na tych obszarach, zmierzaja do realizacji tych samych celów co dyrektywa siedliskowa. Ponieważ uregulowania te ustanawiaja bardziej restrykcyjny system niż wprowadzony $w$ art. 6 tej dyrektywy, stanowiq bardziej rygorystyczny środek ochronny $w$ rozumieniu art. 193 TFUE ${ }^{148}$.

Trybunał zaznaczył, że zgodnie z art. 193 TFUE bardziej rygorystyczne środki powinny być zgłoszone przez dane państwo członkowskie Komisji (czego rząd włoski nie zrobił). Jednocześnie jednak Trybunał wyjaśnił w tym kontekście, że artykuł ten nakłada na państwa członkowskie obowiqzek informowania Komisji o bardziej rygorystycznych środkach ochronnych, które zamierzajq utrzymać lub ustanowić $w$ dziedzinie środowiska naturalnego, lecz nie uzależnia wdrażania planowanych środków od zgody lub braku sprzeciwu Komisji. W tych okolicznościach [...] ani sformułowanie, ani cel badanego przepisu nie przemawia za uznaniem, $i \dot{z}$ uchybienie przez państwa członkowskie cią̇̇cemu na nich na podstawie art. 193 TFUE obowiazkowi notyfikowania samo w sobie powoduje bezprawność tak wydanych bardziej rygorystycznych środków ochronnych (zob. analogicznie wyroki: z dnia 13 lipca 1989 r. w sprawie 380/87 Enichem Base i in., Zb. Orz. TE 2491, par. 20-23; z dnia 23 maja 2000 r. w sprawie C-209/98 Sydha- 
vnens Sten \& Grus, Zb. Orz. TE I-3743, par. 100; a tak்̇e z dnia 6 czerwca 2002 r. $w$ sprawie C-159/00 Sapod Audic, Zb. Or\%. TE I-5031, par. 60-63) ${ }^{149}$.

Skarżące spółki zwróciły uwagę w przypadku tych środków ochronnych, że cel rozwoju nowych i odnawialnych form energii (czyli w tym konkretnym przypadku rozwój farm wiatrowych), ustalony dla polityki Unii w art. 194 ust. 1 lit. c) TFUE winien mieć pierwszeństwo względem celów ochrony środowiska, do których realizacji zmierzają dyrektywa siedliskowa i dyrektywa ptasia. Trybunał nie zgodził się z tym twierdzeniem i wskazał, że art. 194 ust. 1 TFUE stanowi, że polityka Unii $w$ dziedzinie energetyki powinna uwzględniać potrzebę zachowania i poprawy stanu środowiska. Ponadto przepisy takie jak będace przedmiotem postępowania przed sq̨dem krajowym, które zakazuja tylko lokalizacji nowych turbin wiatrowych nieprzeznaczonych do wtasnego użytku na obszarach należacych do sieci Natura 2000, umożliwiając jednocześnie wytaczenie z tego zakazu turbin przeznaczonych na własny użytek o łącznej mocy równej lub niższej niż $20 \mathrm{~kW}$, nie mogq, ze względu na ograniczony zakres zastosowania, zagrozić celowi Unii, którym jest rozwój nowych i odnawialnych form energii. W zwiqzku z powyższym należy uznać, że dyrektywa ptasia i dyrektywa siedliskowa, a w szczególności art. 6 ust. 3 dyrektywy siedliskowej, nie stoja na przeszkodzie bardziej rygorystycznemu krajowemu środkowi ochronnemu, który ustanawia bezwzględny zakaz budowy turbin wiatrowych nieprzeznaczonych do wtasnego użytku na wszystkich OSO w obrębie obszarów należqcych do sieci Natura 2000 bez dokonania jakiejkolwiek oceny skutków dla środowiska określonego planu lub przedsięwzięcia na danym terenie należacym do tej sieci ${ }^{150}$.

W odniesieniu do zagadnienia wykładni dyrektyw 2001/77 i 2009/28 Trybunał stwierdził, iż w przypadku dyrektywy 2001/77, art. 1 tego aktu stanowi, że celem tej dyrektywy jest wspieranie zwiększania udziału odnawialnych źródeł energii $w$ produkcji energii elektrycznej na wewnętrzny rynek energii elektrycznej oraz stworzenia podstaw dla opracowania przysztych ram Wspól-

149 Sprawa C-2/10, par. 53.

150 Sprawa C-2/10, par. 54-58. 
noty $w$ omawianym przedmiocie. $W$ tym celu art. 6 ust. 1 dyrektywy 2001/77 zobowiqzuje państwa członkowskie do dokonania oceny ram ustawowych $i$ wykonawczych $w$ odniesieniu do procedur administracyjnych, w szczególności przyznawania pozwoleń, majacych zastosowanie do przedsiębiorstw elektroenergetycznych wytwarzajacych energię elektrycznq z odnawialnych źródeł energii. Ta procedura oceny ma na celu racjonalizację i ograniczenie przeszkód administracyjnych, jak również zapewnienie obiektywności, przejrzystości i niedyskryminującego charakteru zasad obowiazujących w odniesieniu do tego rodzaju urzqdzeñ ${ }^{151}$.

W ocenie Trybunału sąd krajowy miał wątpliwości, czy wprowadzony zakaz lokalizacji turbin wiatrowych na obszarach należących do sieci Natura 2000 należy uznać za rodzaj przeszkody administracyjnej, o której mowa we wskazanym przepisie dyrektywy 2001/77. W odpowiedzi Trybunał stwierdził w tym zakresie, że co się tyczy $w$ dalszej kolejności dyskryminującego charakteru środka, należy przypomnieć, że zakaz dyskryminacji ustanowiony $w$ art. 6 ust. 1 dyrektywy 2001/77 stanowi jedynie szczególny wyraz ogólnej zasady równości, która jest jedna z podstawowych zasad prawa Unii i która zakazuje, by porównywalne sytuacje byty traktowane $w$ sposób odmienny lub by sytuacje odmienne były traktowane $w$ sposób identyczny, chyba że jest to obiektywnie uzasadnione (zob. w szczególności wyroki: z dnia 5 października 1994 r. w sprawie C-280/93 Niemcy przeciwko Radzie, Zb. Orz. TE I-4973, par. 67; z dnia 3 maja 2007 r. w sprawie C-303/05 Advocaten voor de Wereld, Zb. Orz. TE I-3633, par. 56; z dnia 16 grudnia 2008 r. w sprawie C-127/07 Arcelor Atlantique i Lorraine i in., Zb. Orz. TE I-9895, par. 23) ${ }^{152}$.

Mając powyższe na względzie Trybunał dodał, że $w$ niniejszej sprawie do sqdu odsyłajacego należy zatem zbadanie, czy odmienne traktowanie przedsięwzięcia budowy turbin wiatrowych i przedsięwzięć dotyczqcych innych rodzajów działalności przemystowej, planowanych na obszarach należacych do sieci Natura 2000 może być uzasadnione obiektywnymi różnicami istniejącymi między tymi dwoma rodzajami przedsięwzięć. W tych okolicznościach

151 Sprawa C-2/10, par. 60-61.

152 Sprawa C-2/10, par. 64. 
sqd ten powinien uwzględnić specyfikę turbin wiatrowych, kładac szczególnie nacisk na zagrożenia, jakie mogq one stanowić dla ptactwa, takie jak niebezpieczeństwo zderzenia, zakłócanie i przemieszczenia, efekt bariery zmuszający ptaki do zmiany kierunku badź utrata siedlisk lub ich pogorszenie ${ }^{153}$.

W odniesieniu do nowej dyrektywy 2009/28, Trybunał uznał, że w omawianej sprawie znaczenie ma również art. 13 ust. 1 tego aktu. Zgodnie z tym przepisem państwa członkowskie zapewniają, że wszelkie krajowe przepisy dotyczące procedur autoryzacji, certyfikacji i licencjonowania, które są stosowane w elektrowniach wytwarzających energię elektryczną, energię ciepła lub chłodu z odnawialnych źródeł energii [...], są proporcjonalne i niezbędne. W szczególności państwa członkowskie powinny przyjąć odpowiednie środki, w celu zapewnienia obiektywności, przejrzystości, proporcjonalności i niedyskryminacyjnego charakteru zasad autoryzacji, certyfikacji i licencjonowania oraz uwzględnienia w nich charakterystyki poszczególnych technologii energii odnawialnej tych przepisów. Trybunał uznał, że pomimo trwającego jeszcze okresu implementacji dyrektywy istnieją podstawy, by odpowiedzieć na pytanie postawione przez sąd odsyłający w części dotyczącej wykładni dyrektywy 2009/28, a w szczególności w świetle zasady proporcjonalności, którą wprowadził art. 13 tej dyrektywy wobec procedur administracyjnych dotyczących wydawania pozwoleń dla przedsiębiorstw wytwarzających energię elektryczną ze źródeł odnawialnych ${ }^{154}$.

Na tle art. 13 dyrektywy 2009/28 Trybunał przypomniał, że zasada proporcjonalności określona tym przepisem, którq zalicza się do ogólnych zasad prawa unijnego, wymaga, aby środki przyjmowane przez państwa członkowskie $w$ tej dziedzinie nie wykraczaty poza to, co odpowiednie i konieczne do realizacji uzasadnionych celów, którym majq służyć, przy czym oczywiście tam, gdzie istnieje możliwość wyboru spośród większej liczby odpowiednich rozwiqzań, należy stosować te najmniej dotkliwe, a wynikajace z tego niedogodności nie mogq być nadmierne $w$ stosunku do zamierzonych celów (zob. w szczególności wyroki: z dnia 13 listopada 1990 r.

153 Sprawa C-2/10, par. 65-66.

154 Sprawa C-2/10, par. 72. 
w sprawie C-331/88 Fedesa i in., Zb. Orz. TE I-4023, par. 13; z dnia 5 października 1994 r. w sprawach połaczonych C-133/93, C-300/93 i C-362/93 Crispoltoni i in., Zb. Orz. TE I-4863, par. 41) ${ }^{155}$. Następnie Trybunał dodał, że zadaniem sądu odsyłającego jest zbadanie proporcjonalności rozważanego środka krajowego. Sąd ten powinien $w$ szczególności uwzględnić okoliczność, że uregulowania będace przedmiotem toczqcego się przed nim postępowania sq ograniczone tylko do turbin wiatrowych, z wytaczeniem innych form produkcji energii elektrycznej z odnawialnych źródet takich jak urzqdzenia fotowoltaiczne. Ponadto zakaz miałby zastosowanie wytącznie do nowych turbin wiatrowych do celów komercyjnych, ponieważ turbiny wiatrowe przeznaczone do wtasnego użytku o łacznej mocy równej lub niższej niż $20 \mathrm{~kW}$ sq wyłaczone z zakresu jego zastosowania ${ }^{156}$.

\section{GOSPODARKA ODPADAMI}

\section{IX.1. WYROK TRYBUNAŁU Z DNIA 15 LIPCA 2010 R. W SPRAWIE C-512/09 KOMISJA EUROPEJSKA PRZECIWKO REPUBLICE GRECKIEJ ${ }^{157}$}

Przedmiot: uchybienie zobowiązaniom państwa członkowskiego - brak ustanowienia w przewidzianym terminie przepisów niezbędnych w celu dostosowania się do dyrektywy 2006/66/ WE Parlamentu Europejskiego i Rady z dnia 6 września 2006 r. w sprawie baterii i akumulatorów oraz zużytych baterii i akumulatorów oraz uchylającej dyrektywę 91/157/EWG.

Sentencja:

1) Nie ustanawiając $w$ wyznaczonym terminie przepisów ustawowych, wykonawczych i administracyjnych

155 Sprawa C-2/10, par. 73.

156 Sprawa C-2/10, par. 74.

157 Dz. Urz. UE C 246 z 11.09.2010, s. 13; uzasadnienie wyroku dostępne jedynie w greckiej i francuskiej wersji językowej. 
niezbędnych w celu dostosowania się do dyrektywy 2006/66/WE Parlamentu Europejskiego i Rady z dnia 6 września 2006 r. w sprawie baterii i akumulatorów oraz zużytych baterii i akumulatorów oraz uchylającej dyrektywę 91/157/EWG, Republika Grecka uchybiła zobowiązaniom, które ciążą na niej na mocy tej dyrektywy.

2) Republika Grecka zostaje obciążona kosztami postępowania.

\section{IX.2. WYROK TRYBUNAEU Z DNIA 29 LIPCA $2010 \mathrm{R}$. W SPRAWIE C-513/09 KOMISJA EUROPEJSKA PRZECIWKO KRÓLESTWU BELGII ${ }^{158}$}

Przedmiot: uchybienie zobowiązaniom państwa członkowskiego - brak przyjęcia w wyznaczonym terminie wszelkich przepisów niezbędnych w celu zastosowania się do dyrektywy 2006/66/WE Parlamentu Europejskiego i Rady z dnia 6 września 2006 r. w sprawie baterii i akumulatorów oraz zużytych baterii i akumulatorów oraz uchylającej dyrektywę 91/157/EWG.

Sentencja:

1) Nie przyjmując $w$ wyznaczonym terminie wszelkich przepisów ustawowych, wykonawczych i administracyjnych niezbędnych w celu zastosowania się do dyrektywy 2006/66/WE Parlamentu Europejskiego i Rady z dnia 6 września 2006 r. w sprawie baterii i akumulatorów oraz zużytych baterii i akumulatorów oraz uchylającej dyrektywę 91/157/EWG Królestwo Belgii uchybiło zobowiązaniom ciążącym na nim na mocy tej dyrektywy.

2) Królestwo Belgii zostaje obciążone kosztami postępowania.

158 Dz. Urz. UE C 246 z 11.09.2010, s. 14; uzasadnienie wyroku dostępne jedynie we francuskiej wersji językowej. 


\section{IX.3. WYROK TRYBUNAŁU Z DNIA 29 LIPCA 2010 R. \\ W SPRAWIE C-515/09 KOMISJA EUROPEJSKA PRZECIWKO REPUBLICE ESTOŃSKIEJ ${ }^{159}$}

Przedmiot: uchybienie zobowiązaniom państwa członkowskiego - brak ustanowienia w przewidzianym terminie wszystkich przepisów niezbędnych do zastosowania się do dyrektywy 2006/21/WE Parlamentu Europejskiego i Rady z dnia 15 marca 2006 r. w sprawie gospodarowania odpadami pochodzącymi z przemysłu wydobywczego oraz zmieniającej dyrektywę 2004/35/WE.

Sentencja:

1) Nie ustanawiając $w$ przewidzianym terminie przepisów ustawowych, wykonawczych i administracyjnych niezbędnych dla zastosowania się do dyrektywy 2006/21/WE Parlamentu Europejskiego i Rady z dnia 15 marca 2006 r. w sprawie gospodarowania odpadami pochodzącymi z przemysłu wydobywczego oraz zmieniającej dyrektywę 2004/35/WE Republika Estońska uchybiła zobowiązaniom ciążącym na niej na mocy tej dyrektywy.

2) Republika Estońska zostaje obciążona kosztami postępowania.

\section{IX.4. WYROK TRYBUNAŁU Z DNIA 29 LIPCA 2010 R. W SPRAWIE C-35/10 KOMISJA EUROPEJSKA PRZECIWKO REPUBLICE FRANCUSKIEJ ${ }^{160}$}

Przedmiot: uchybienie zobowiązaniom państwa członkowskiego - brak ustanowienia w przewidzianym terminie wszystkich przepisów niezbędnych do zastosowania się do dyrektywy 2006/21/WE Parlamentu Europejskiego i Rady z dnia 15 mar-

159 Dz. Urz. UE C 246 z 11.09.2010, s. 14; uzasadnienie wyroku dostępne jedynie w estońskiej i francuskiej wersji językowej.

160 Dz. Urz. UE C 246 z 11.09.2010, s. 16; uzasadnienie wyroku dostępne jedynie we francuskiej wersji językowej.

PRIEELĄ PRAWA OCHRONY ŚRODOWISWA 
ca 2006 r. w sprawie gospodarowania odpadami pochodzącymi z przemysłu wydobywczego oraz zmieniającej dyrektywę 2004/35/WE.

Sentencja:

1) Nie ustanawiając $\mathrm{w}$ przewidzianym terminie przepisów ustawowych, wykonawczych i administracyjnych niezbędnych dla zastosowania się do dyrektywy 2006/21/ WE Parlamentu Europejskiego i Rady z dnia 15 marca 2006 r. w sprawie gospodarowania odpadami pochodzącymi z przemysłu wydobywczego oraz zmieniającej dyrektywę 2004/35/WE Republika Francuska uchybiła zobowiązaniom ciążącym na niej na mocy tej dyrektywy.

2) Republika Francuska zostaje obciążona kosztami postępowania.

\section{IX.5. WYROK TRYBUNAEU Z DNIA 2 GRUDNIA 2010 R. \\ W SPRAWIE C-526/09 KOMISJA EUROPEJSKA PRZECIWKO REPUBLICE PORTUGALSKIEJ ${ }^{161}$}

Przedmiot: uchybienie zobowiązaniom państwa członkowskiego - naruszenie art. 11 ust. 1 i 2 dyrektywy Rady 91/271/ EWG z dnia 21 maja 1991 r. dotyczącej oczyszczania ścieków komunalnych - koncesja na odprowadzanie ścieków - „Estação de Serviço Sobritos".

Sentencja:

1) Umożliwiając odprowadzanie ścieków przemysłowych z zakładu przemysłowego Estação de Serviço Sobritos Lda znajdującego się na obszarze miejskim Matosinhos nie wydawszy $w$ tym celu odpowiedniego zezwolenia Republika Portugalska uchybiła zobowiązaniom, które na niej ciążą na mocy art. 11 ust. 1 i 2 dyrektywy Rady 91/271/EWG z dnia 21 maja 1991 r. dotyczącej oczyszczania ścieków komunalnych.

161 Dz. Urz. UE C 030 z 29.01.2011, s. 9; uzasadnienie wyroku dostępne jedynie w portugalskiej i francuskiej wersji językowej. 
2) Republika Portugalska zostaje obciążona kosztami postępowania.

\section{IX.6. WYROK TRYBUNAŁU Z DNIA 8 WRZEŚNIA 2011 R. W SPRAWIE C-220/10 KOMISJA EUROPEJSKA PRZECIWKO REPUBLICE PORTUGALSKIEJ ${ }^{162}$}

Przedmiot: uchybienie zobowiązaniom państwa członkowskiego - naruszenie dyrektywy Rady 91/217/EWG z dnia 21 maja 1991 r. dotyczącej oczyszczania ścieków komunalnych. Sentencja:

1) Republika Portugalska

- poprzez zaklasyfikowanie jako obszarów mniej wrażliwych wszystkich wód przybrzeżnych wyspy Madery i wyspy Porto Santo;

- poprzez poddanie mniej rygorystycznemu oczyszczaniu, niż przewidzianemu $\mathrm{w}$ art. 4 dyrektywy Rady 91/217/EWG z dnia 21 maja 1991 r. dotyczącej oczyszczania ścieków komunalnych, ścieków komunalnych pochodzących z aglomeracji, których liczba mieszkańców jest wyższa od 10000, takich jak Funchal i Câmara de Lobos, odprowadzanych do wód przybrzeżnych wyspy Madery;

- poprzez brak zagwarantowania $\mathbf{w}$ odniesieniu do aglomeracji położonej w estuarium rzeki Tag, to znaczy Quanta do Conde, istnienia systemów zbierania ścieków komunalnych zgodnie $\mathrm{z}$ postanowieniami art. 3 tej dyrektywy;

- poprzez brak zagwarantowania, w odniesieniu do aglomeracji Albufeira/Armação de Pêra, Beja, Chaves i Viseu, oraz w odniesieniu do czterech aglomeracji, które odprowadzają ścieki na lewym brzegu estuarium rzeki Tag, to znaczy Barreiro/Moita, Corroios/

162 Dz. Urz. UE C 311 z 22.10.2011, s. 12; uzasadnienie wyroku dostępne jedynie w portugalskiej i francuskiej wersji językowej. 
Quanta da Bomba, Quanta do Conde i Seixal, bardziej rygorystycznego oczyszczania niż przewidziane w art. 4 rzeczonej dyrektywy, uchybiła zobowiązaniom ciążącym na niej na mocy art. 3, 5 i 6 dyrektywy 91/271.

2) Republika Portugalska zostaje obciążona kosztami postępowania.

\section{ZINTEGROWANE ZAPOBIEGANIE ZANIECZYSZCZENIOM I ICH KONTROLA}

\section{X.1. WYROK TRYBUNAŁU Z DNIA 7 PAŹDZIERNIKA 2010 R. W SPRAWIE C-49/10 KOMISJA EUROPEJSKA PRZECIWKO REPUBLICE SŁOWENII ${ }^{163}$}

Przedmiot: uchybienie zobowiązaniom państwa członkowskiego - naruszenie art. 5 ust. 1 dyrektywy Parlamentu Europejskiego i Rady 2008/1/WE z dnia 15 stycznia 2008 r. dotyczącej zintegrowanego zapobiegania zanieczyszczeniom i ich kontroli - warunki udzielania pozwoleń na istniejące instalacje - obowiązek zapewnienia, by takie instalacje były eksploatowane zgodnie z wymogami dyrektywy

Sentencja:

1) Nie przyjmując $w$ przewidzianym terminie wszystkich niezbędnych środków $\mathbf{w}$ dziedzinie udzielania pozwoleń na instalacje przemysłowe zgodnie $\mathrm{z}$ art. 5 ust. 1 dyrektywy Parlamentu Europejskiego i Rady 2008/1/WE z dnia 15 stycznia 2008 r. dotyczącej zintegrowanego zapobiegania zanieczyszczeniom i ich kontroli, Republika Słowenii uchybiła zobowiązaniom ciążącym na niej na mocy tej dyrektywy.

2) Republika Słowenii zostaje obciążona kosztami.

163 Dz. Urz. UE C 328 z 04.12.2010, s.9; uzasadnienie wyroku dostępne jedynie w słoweńskiej i francuskiej wersji językowej. 


\section{X.2. WYROK TRYBUNAEU (SZÓSTA IZBA) Z DNIA 18 LISTOPADA 2010 R. W SPRAWIE C-48/10 KOMISJA EUROPEJSKA PRZECIWKO KRÓLESTWU HISZPANII ${ }^{164}$}

Przedmiot: uchybienie zobowiązaniom państwa członkowskiego - naruszenie art. 5 ust. 1 dyrektywy Parlamentu Europejskiego i Rady 2008/1/WE z dnia 15 stycznia 2008 r. dotyczącej zintegrowanego zapobiegania zanieczyszczeniom i ich kontroli- instalacje mogące mieć wpływ na emisje do powietrza, środowiska wodnego lub gleby oraz na zanieczyszczenie - warunki udzielania pozwoleń dla istniejących instalacji.

Sentencja:

1) Nie podejmując niezbędnych środków w celu zagwarantowania, że właściwe władze zapewnią, poprzez udzielenie pozwoleń zgodnie $z$ art. 6 i 8 dyrektywy Parlamentu Europejskiego i Rady 2008/1/WE z dnia 15 stycznia 2008 r. dotyczącej zintegrowanego zapobiegania zanieczyszczeniom i ich kontroli lub, w odpowiedni sposób, poprzez ponowne zbadanie warunków i, w odpowiednim przypadku, poprzez uaktualnienie pozwoleń na istniejące instalacje, aby najpóźniej do dnia 30 października 2007 r., instalacje te były eksploatowane zgodnie z wymogami art. 3, 7, 9, 10 i 13, art. 14 lit. a) i b) i art. 15 ust. 2 tej dyrektywy, z zastrzeżeniem innych szczególnych przepisów prawa Unii, Królestwo Hiszpanii uchybiło zobowiązaniom ciążącym na nim na mocy art. 5 ust. 1 omawianej dyrektywy.

2) Królestwo Hiszpanii zostaje obciążone kosztami postępowania.

164 Dz. Urz. UE C 013 z 15.01.2011, s. 15; uzasadnienie wyroku dostępne jedynie w hiszpańskiej i francuskiej wersji językowej. 